LUCAS PLADEVALL MOREIRA

Proposta de sensor de amido em folha de plantas

São Paulo

2017 


\section{Proposta de sensor de amido em folha de plantas}

Dissertação apresentada à Escola Politécnica da Universidade de São Paulo para obtenção do título de Mestre em Ciências pelo Programa de Pós-graduação em Engenharia Mecânica.

Área de Concentração: Engenharia de Controle e Automação Mecânica

Orientador: Prof. Dr. Marcos Ribeiro Pereira Barretto

São Paulo 
Este exemplar foi revisado e corrigido em relação à versão original, sob responsabilidade única do autor e com a anuência de seu orientador.

São Paulo, de de

Assinatura do autor:

Assinatura do orientador:

\section{Catalogação-na-publicação}

Moreira, Lucas Pladevall

Proposta de sensor de amido em folha de plantas / L. P. Moreira -versão corr. -- São Paulo, 2017.

$79 \mathrm{p}$.

Dissertação (Mestrado) - Escola Politécnica da Universidade de São Paulo. Departamento de Engenharia Mecatrônica e de Sistemas Mecânicos.

1.Amido 2.Sensores 3.Automação para agricultura 4.Processamento de imagens I.Universidade de São Paulo. Escola Politécnica. Departamento de Engenharia Mecatrônica e de Sistemas Mecânicos II.t. 
Dissertação de autoria de Lucas Pladevall Moreira, sob o título "Proposta de sensor de amido em folha de plantas", apresentada à Escola Politécnica da Universidade de São Paulo, para obtenção do título de Mestre em Ciências pelo Programa de Pós-graduação em Engenharia Mecânica, na área de concentração Engenharia de Controle e Automação Mecânica, aprovada em de de pela comissão julgadora constituída pelos doutores:

Prof. Dr.

\section{Presidente}

Instituição:

Prof. Dr.

Instituição:

Prof. Dr.

Instituição: 


\section{Resumo}

MOREIRA, Lucas Pladevall. Proposta de sensor de amido em folha de plantas.

Para contribuir com o desenvolvimento da automação agrícola, este trabalho descreve abordagens metodológicas e cria uma proposta para a elaboração de um sensor de medição de amido em folhas de plantas, para a quantificação de amido nas folhas das plantas, utilizando técnicas de processamento de imagem em cortes de secção transversal de folhas de goiabeira Psidium guajava $L$ marcadas com Lugol para quantificar após calibração os grãos de amido presentes na folha. Os resultados obtidos foram satisfatórios, com redução do tempo necessário para obtenção da medição, propiciando sua utilização como sensor em sistemas de controle de crescimento de plantas em malha fechada, em especial aqueles que utilizam iluminação artificial.

Palavras-chave: Amido. Sensores. Automação para agricultura. Processamento de imagens. 


\begin{abstract}
MOREIRA, Lucas Pladevall. Leaf starch sensor proposition for closed-loop control of plant growth

To contribute to the development of agricultural automation, this work describes methodological approaches and creates a proposal for the elaboration of a starch measurement sensor in plant leaves, for the quantification of starch in the leaves of the plants, using image processing techniques in cross-sections of Psidium guajava $L$ guava leaves marked with Lugol to quantify after calibration the starch grains present in the leaf. The results obtained were satisfactory, with a reduction in the time required to obtain the measurement, favoring its use as a sensor in closed-loop plant growth control systems, especially those using artificial lighting.
\end{abstract}

Keywords: Starch. Sensors. Automation for agriculture. Image processing. 


\section{Lista de figuras}

Figura 1 Representação esquemática de célula vegetal (Evert e Eichhorn 2014) .................... 18

Figura 2 Padrão de vascularização em folhas; (a-d) Arabidopsis thaliana, exemplo de dicotiledônea; (e-h) Zea mays, exemplo de monocotiledônea (Beck 2005) modificado

Figura 3 Representações tridimensionais de secção transversal de folha (Campbell, Reece e Mitchell. 1999, Weier 1982)

Figura 4 (a) Destaque de uma célula do parênquima paliçádico de uma folha. Nota-se grande quantidade de cloroplastos com grãos de amido. (b) Secção transversal de folha de Nerium oleander, destaque para uma camada de células epidérmicas, logo seguida por duas camas de células hipodérmicas, seguida do parênquima paliádico (parte superior do mesofilo) e parênquima esponjoso (parte inferior do mesofilo) (Buvat 1989).

Figura 5 Padrão de vascularização em dicotiledôneas (a-b), com diferentes ordens de veias ramificadas, e monocotiledôdenas (c-b) com diferentes ordens de veias paralelas. (Beck 2005) 23

Figura 6 (a) Exemplo de folha simples de gramínea, (b) Exemplo de folha composta de Scheffeleria sp. (Bold 1967)..... 24

Figura 7 Orientação dos cloroplastos em (a) sob luz fraca, (b) sob luz forte (Evert e Eichhorn 2014)

Figura 8 Fotossistemas I e II e atividade na membrana tilacóide do cloroplasto

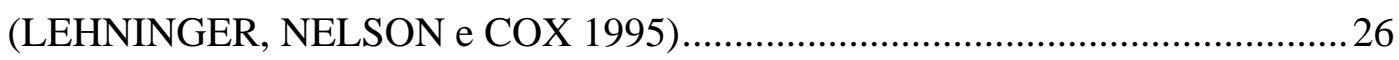

Figura 9 Síntese de Sacarose e Amido (TAIZ e ZEIGER 2002) ...........................................27

Figura 10 Diagrama ilustrando a resposta de plantas sensíveis fotoperiodicamente à progressão do dia ao longo das estações do ano, para diferentes latitudes (Weier 1982) 29

Figura 12 - Passos fundamental em processamento de imagens digitais (Gonzalez e Woods 1992).

Figura 13 - Curvas de sintese e degradação da quantidade de amido nas folha de sorgo ( $\mu$ g AMIDO/mg Massa Seca)

Figura 14 Sorgo, marcado Lugol 2\%,

Figura 15 cana-de-açúcar, marcador lugol, remoção de pigmentos solução hipoclorito de sódio $1 \%$ 
Figura 16 - Secção transversal de folha de goiabeira Psidium guajava L, coletadas em diferentes horários. C1 (0h00), C2(7h00), C3(12h00), C4(15h00) e C5(18h00)... 42

Figura 17 - Corte Avena ventricosa em destaque para Cloroplasto em MET aumento 33.000x, (E) membranas de envelopamento do cloroplasto, (S) vista lateral das granas, ribossomos densamente observados e circulados dentro do estroma, (G) grão de amido, (F) sistema de membranas interconectando as granas (Gunning e Steer 1975). 43

Figura 18 imagem de folha de Psidium guajava $L$ em aumentos de lente objetiva (a)10x,(b) 20x,(c) 40x e (d) 100x (ML), espessura de corte 10 $\mu \mathrm{m}$, marcador lugol, fixador FAA50, coletada $18 \mathrm{~h}$. 44

Figura 19 - C1 - corte secção transversal folha de goiabeira Psidium guajava L, amostrada Oh. 46

Figura 20 - C2- corte secção transversal folha de goiabeira Psidium guajava L, amostrada 7h. 47

Figura 21 - C3- corte secção transversal folha de goiabeira Psidium guajava L, amostrada $12 \mathrm{~h}$.

Figura 22 - C4- corte secção transversal folha de goiabeira Psidium guajava L, amostrada $15 \mathrm{~h}$. 48

Figura 23 - C5- corte secção transversal folha de goiabeira Psidium guajava L, amostrada 18h. 48

Figura 24 (a) RGB com ganho em contraste, (b) componente R, (c) componente G, (d) componente B.

Figura 25(a) CMY com ganho em contraste, (b) componente C, (c) componente M, (d) componente Y.

Figura 26 (a) HSV com ganho em contraste, (b) componente H, (c) componente S, (d) componente $\mathrm{V}$.

Figura 27 - Amostra de folha padrão, destaque para amostras de discos de 1,7cm de diâmetro e zonas de amostragem retangulares para corte de secção transversal. 52

Figura 28 - Quantificação pelo método descrito em (Amaral, et al. 2007) para as amostras A e A*, B e B* e C e C* para os horários de 1 a 5. 53

Figura 29 - Etapas do processamento de imagem. A - imagem original; B- Imagem em escala de cinza destacada do canal verde (G); C- Imagem binarizada; D - Imagem com regiões destacadas por espalhamento de cor para facilitar interpretação de 
regiões de interesse; E- Imagem com objetos de interesse destacados e etiquetados na imagem original. 56

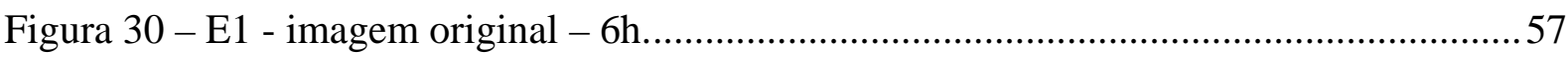

Figura 31 - E1 - Imagem em escala de cinza destacada do canal verde (G)..........................57

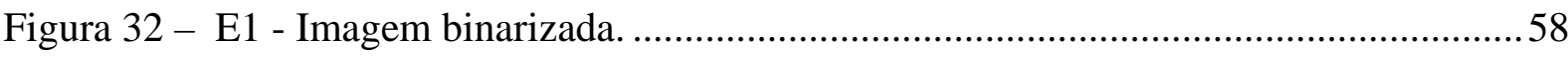

Figura 33 - E1 - Imagem com regiões destacadas por espalhamento de cor para facilitar interpretação de regiões de interesse.

Figura 34 - E1 - Imagem com objetos de interesse destacados e etiquetados na imagem original. 59

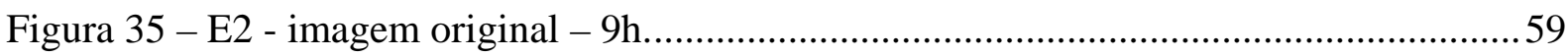

Figura 36 - E2 - Imagem em escala de cinza destacada do canal verde (G)..........................60

Figura 37 - E2 - Imagem binarizada. 60

Figura 38 - E2 - Imagem com regiões destacadas por espalhamento de cor para facilitar interpretação de regiões de interesse.

Figura 39 - E2 - Imagem com objetos de interesse destacados e etiquetados na imagem original. 61

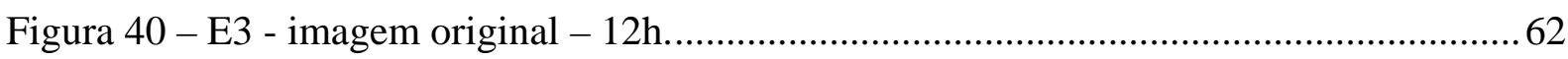

Figura 41 - E3 - Imagem em escala de cinza destacada do canal verde (G)..........................62

Figura 42 - E3 - Imagem binarizada. 63

Figura 43 - E3 - Imagem com regiões destacadas por espalhamento de cor para facilitar interpretação de regiões de interesse.

Figura 44 - E3 - Imagem com objetos de interesse destacados e etiquetados na imagem original. 64

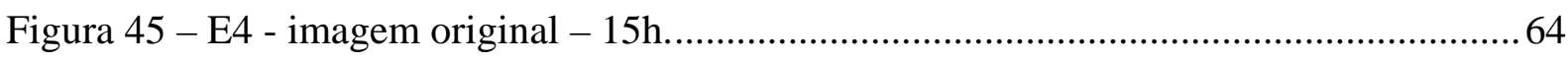

Figura 46 - E4 - Imagem em escala de cinza destacada do canal verde (G)..........................65

Figura 47 - E4 - Imagem binarizada. 65

Figura 48 - E4 - Imagem com regiões destacadas por espalhamento de cor para facilitar interpretação de regiões de interesse. 66

Figura 49 - E4 - Imagem com objetos de interesse destacados e etiquetados na imagem original. 66

Figura 50 - E5 - imagem original - 18h. 67

Figura 51 - E5 - Imagem em escala de cinza destacada do canal verde (G) 67

Figura 52 - E5 - Imagem binarizada. 68 
Figura 53 - E5 - Imagem com regiões destacadas por espalhamento de cor para facilitar interpretação de regiões de interesse. 68

Figura 54 - E5 - Imagem com objetos de interesse destacados e etiquetados na imagem

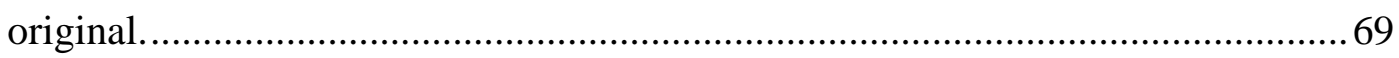

Figura 55 - Resultado da extração Análise de Imagem. ….................................................. 70

Figura 56 - Resultado da extração Química / Enzimática descrita em (Amaral, et al. 2007).. 71

Figura 57 - Resultado da extração Análise de Imagem aplicado ganho k. .75 


\section{Lista de tabelas}

Tabela 1 - Resultado com valores de área de pixels para as amostras de E1 à E5, amostras de 1 à 6 correspondentes à folha $\mathrm{A}$, de 7 à 12 correspondentes a folha $\mathrm{B}$ e amostras de 13 à 18 correspondentes à folha $\mathrm{C}$

Tabela 2 - Resultado com valores de ug AMIDO /mg Massa Seca de amostras de E1 à E5, amostras de 1 e 2 correspondentes à folha $\mathrm{A}$, de 3 e 4 correspondentes Á folha $\mathrm{B}$ e amostras de 5 e 6 correspondentes à folha $\mathrm{C}$, renomeadas para amostras reais

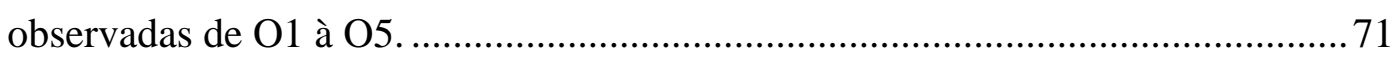

Tabela 3 - Conjunto de pontos observados com ganho k. ….............................................. 73

Tabela 4 - Resultado dos testes de independência................................................................ 74 
Sumário

1 Introdução ............................................................................ 12

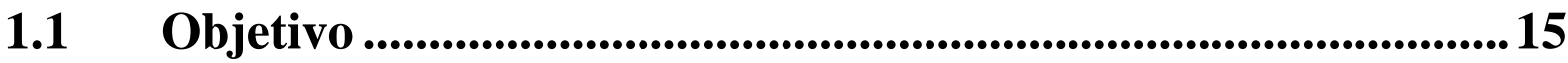

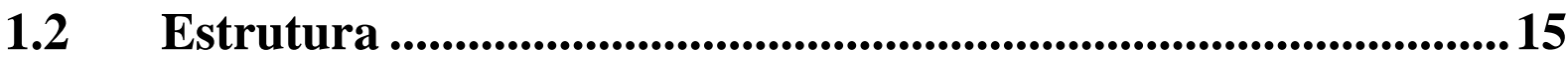

2 Revisão Bibliográfica....................................................... 17

2.1 Estrutura da folha ..........................................................18

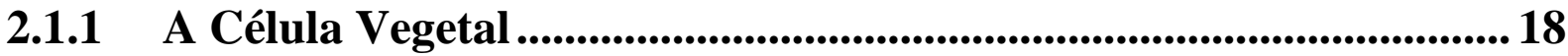

2.1.2 Estrutura da folha ....................................................................19

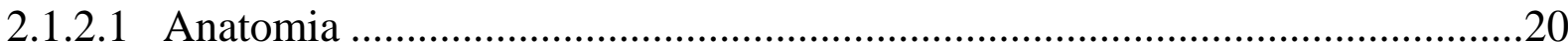

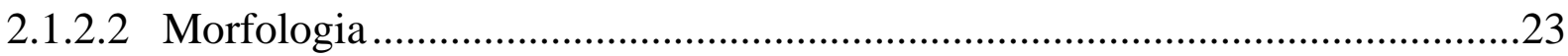

2.1.3 Luz e controle do crescimento...................................................... 24

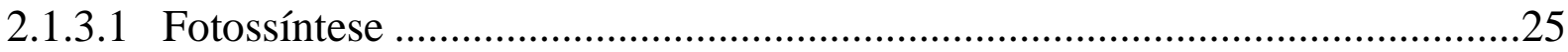

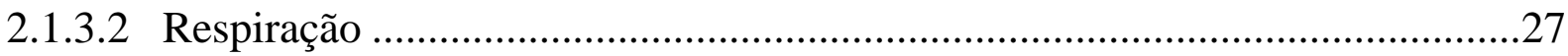

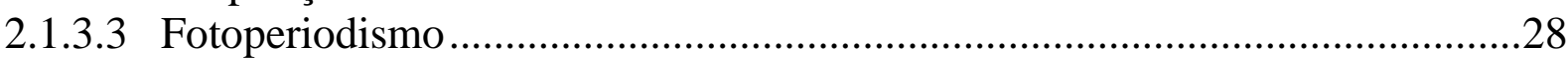

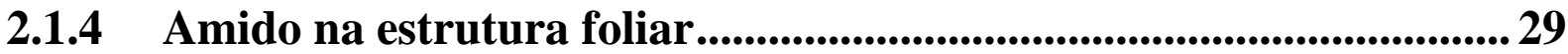

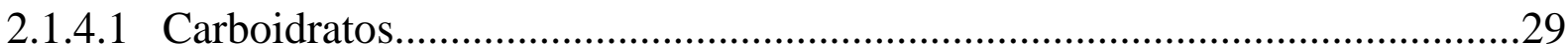

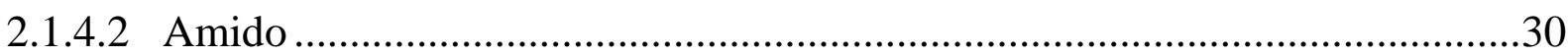

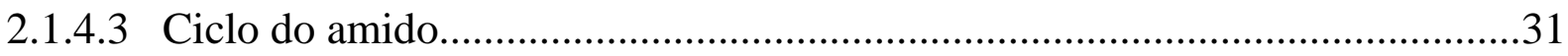

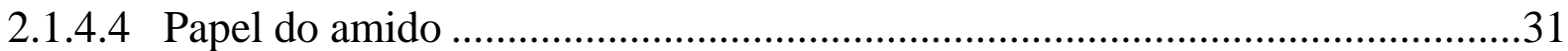

2.2 Característica do ciclo circadiano para controle do amido......32

2.3 Métodos de Medição de Amido...................................................33

2.3.1 Métodos de extração e dosagem química............................................. 33

2.3.2 Método de extração química e dosagem enzimática........................... 33

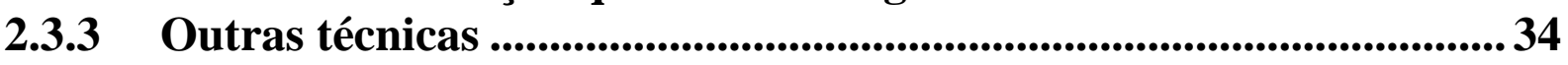

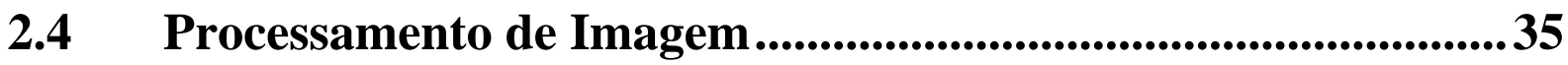

2.4.1 Pré-processamento de Imagem ......................................................... 35

2.4.2 Problema de Segmentação.................................................................36

2.4.2.1 Métodos baseados em limiar de histograma...............................................36

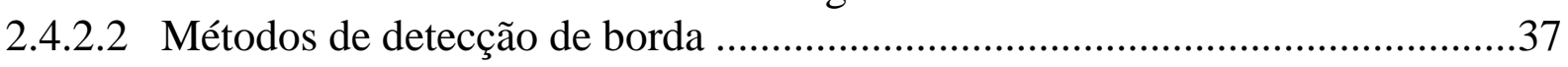

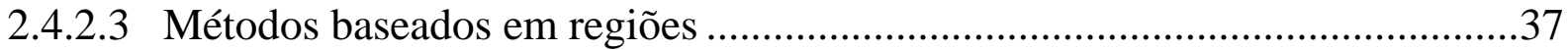

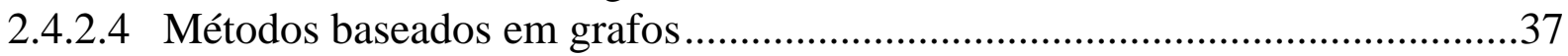

2.4.2.5 Métodos baseados em aprendizado de máquina..............................................38

2.4.2.6 Métodos baseados em modelos estatísticos...................................................39

3 Materiais e Métodos ............................................................. 40

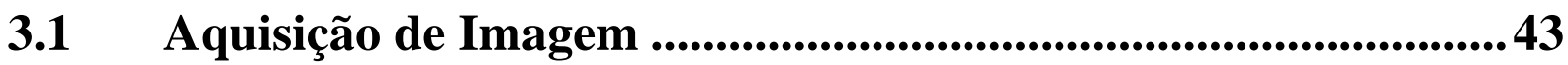

$4 \quad$ Abordagem inicial.............................................................. 45

4.1 Abordagem por contagem de estruturas ......................................45

4.2 Abordagem por área e cor ............................................................45

4.3 Ensaios preliminares com imagens ........................................46 
$5 \quad$ Proposta..................................................................................... 51

5.1 Fase preliminar ...............................................................51

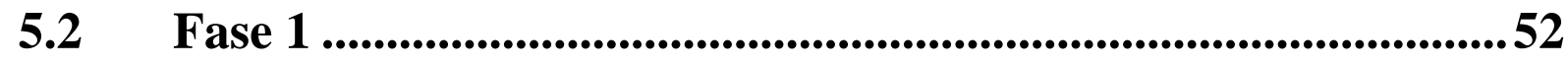

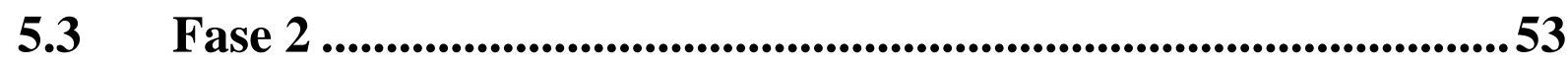

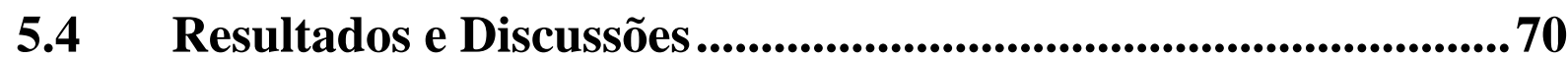

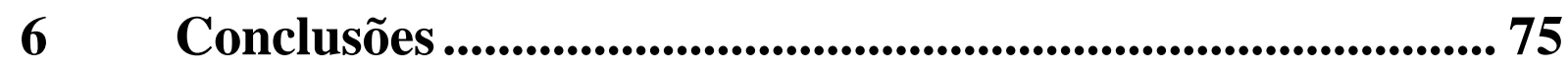

Referências ............................................................................. 77 


\section{Introdução}

O estudo sistemático do crescimento dinâmico de plantas tem seu modelamento como um desafio real para pesquisadores, dado a interdisciplinaridade dos aspectos levados em conta na elaboração, no formalismo matemático, no conhecimento sobre botânica e fisiologia, agronomia, engenharia e ciência da computação com criação de possibilidades de operação mais ricas e produtivas (Reffye e Hu 2003).

A automação agrícola vem se desenvolvendo significativamente no mundo, de extrema importância em produção de alta tecnologia, com precisão e confiabilidade que com o avanço em sistemas de produção agrícolas com alto grau de controle e possibilidade de automação chamam a atenção para sua alta produtividade e baixo consumo de recursos, a exemplo da produção de minitubérculos básicos de batata com técnica de produção sem solo, aeroponia (Factor, et al. 2007).

Ainda segundo Factor (2007), o sistema aeropônico destaca necessidade de nível elevado de controle do processo de crescimento. O processo de crescimento em sistema aeropônico elimina influências indesejadas como a presença do solo, permitindo avaliar o crescimento de uma planta por inteiro bem como facilita a elaboração de modelos de crescimento dinâmico baseados em observação com condições de parâmetros relevantes altamente controláveis.

A dinâmica da espessura das folhas de plantas pode ser utilizada como parâmetro de controle para sistemas de irrigação ou aspersão em sistemas aeropônicos, cuja medida fornece informações fisiológicas importantes e confiáveis na aplicação de irrigação de precisão, permitindo fornecer as plantas água somente quando elas necessitam, economizando o máximo de água-doce possível (SEELING, STONER e LINDEN 2011).

Analisando-se as condições de contorno de um sistema de crescimento dinâmico, uma planta em aeroponia tem como parâmetros relevantes observáveis a temperatura e humidade relativa do ar ambiente, a água e solução nutritiva aspergida diretamente nas raízes, a luz solar ou suplementação luminosa de radiação solar utilizada no processo fotossintético, essencial para o crescimento vegetativo e reprodutivo das plantas, abrindo rico caminho para introduzir um sistema de controle elaborado para o crescimento de plantas (Mello 2014).

Outro ponto interessante em relação ao crescimento de plantas, do ponto de vista de controle é a existência de evidência para o papel do relógio biológico na regulação da quebra do amido, um mecanismo temporizador que corresponde à degradação do amido para noite com comprimento esperado, bem como relações com o correto balanço de uma ampla lista de 
condições como duração do dia, concentração de $\mathrm{CO}_{2}$, suprimento de nutrientes e água, indicando um sistema fechado de elementos atuando nas variações de taxas de síntese e degradação de amido (Stitt e Zeeman 2012).

Stitt e Zeeman elucidam em seu trabalho que mesmo pequenas variações na taxa de processamento do amido nas folhas afeta o metabolismo e crescimento da planta, onde uma prematura exaustão de amido leva a um jejum de carbono à noite acompanhado rapidamente de mudança metabólica e de expressão gênica com inibição de crescimento que só pode ser revertido de uma a duas horas após o início de luz do dia subsequente, como também observado por Graf (2010) pontuando o crescimento da planta dirigido pelo processo de fixação fotossintética de carbono do $\mathrm{CO}_{2}$ durante o dia, armazenado usualmente na forma de amido para seu metabolismo noturno dando suporte ao crescimento, e por Pantin (2011) onde mede a taxa de extensão do crescimento durante o dia e durante a noite para folha de Arabdopsis em diferentes estágios de crescimento, onde fica clara a relação entre taxa de processamento de amido e crescimento das folhas jovens, e mais de seu estudo recente, Pantin mostra que a expansão do crescimento de folhas bem jovens é mais rápida durante o dia do que à noite e muito sensível a distúrbios na degradação e síntese de amido, indicando basicamente uma limitação por carbono, ao passo que para folhas mais velhas e estágios mais avançados de crescimento as folhas ficam menos suscetíveis a tais distúrbios passando à sensibilidade por suprimento de água.

Tais indicações levam a observar com mais cuidado o papel do amido contido nas folhas das plantas como objeto a ser medido e possível parâmetro para um sistema de controle de crescimento de plantas. Para definir como a degradação do amido é regulada Stitt e Zeeman (2012) indicam que será necessário desenvolver métodos capazes de medir diferenças na superfície do grão de amido e avaliar seu impacto, além de indicar um desafio emergente no sentido de entender como as várias vias de sinalização interagem e permitem uma contínua e dinâmica regulação do crescimento e como sua operação é integrada com sinais de luz e de relógio biológico, havendo uma clara necessidade de analisar detalhadamente a relação entre estoque de carboidratos e metabolismo para o crescimento através das condições ambientais que cercam o processo em diferentes espécies de plantas.

Entende-se para tal que há uma necessidade clara de ampliar o conhecimento e entendimento do papel do amido nas folhas, com ótima aplicabilidade em sistemas de controle de crescimento, sendo fundamental para tal a existência de métodos de medição de amido em folhas de plantas. 
Há uma longa história no estudo do papel do amido nas folhas (Zhu, et al. 2015), desde a primeira observação de grão de amido em corpos de clorofila de plantas verdes em 1847 por Von Mohl (Brown e Morris 1893) até recentes estudos como de Zhu avaliando propriedades térmicas e estruturas moleculares internas do grão de amido indicando que ciclos diurnos influenciam na estrutura e propriedades termodinâmicas do amido nas folhas de Arabidopsis.

Esforços no sentido de aprimorar a eficiência fotossintética deverão resultar em aumento das taxas de assimilação de carbono em cultivares de plantas produtivas nos próximos anos, traduzindo aumento em assimilação em produtividade no campo, mas requer uma grande compreensão da relação entre crescimento e assimilação, em como o carbono é fornecido para o metabolismo e crescimento noturno, possibilitando descobertas além do simples crescimento por ciclo claro-escuro, revelando a importância que deve ser considerada no futuro da economia pelo papel do carbono no aumento da produtividade, como também elucidações acerca das vias de sinalizações e conexões com relógio biológico e controle de enzimas presentes nos cloroplastos compondo um desafio interessante para o futuro (Graf e Smith 2011).

Em estudos com outros cultivares comerciais, verifica-se que a medição do processo de fotossíntese do dossel de uma planta vascularizada larga como o tomate não é fácil. Existem muitos progressos na modelagem de fotossíntese em relação a concentração de $\mathrm{CO}_{2}$ (Edwards, Jolliffe e Ehret 2010) que demonstrando a necessidade de métodos de sensoriamento, diretos ou indiretos, relacionados ao processo fotossintético, fixação de $\mathrm{CO}_{2}$, armazenamento e utilização de amido, para aprimoramento de modelos e validação, assim como permitir o desenvolvimento de novos sistemas de controle de crescimento de plantas.

Recentes avanços foram obtidos na compreensão da regulação da síntese do amido como resposta à sinais ambientais e metabólicos, contudo necessitando desenvolver mais trabalhos para atingir a melhor compreensão dos aspectos importantes da regulação da síntese do amido nas folhas e a aplicação do conhecimento em melhoramento de cultivares de plantações (Geigenberger 2011) e estudos contemplando abordagens acerca de propriedades transitórias e de armazenamento do amido, examinando fluxo e controle metabólico da síntese e degradação do amido, indagando sobre serem dois lados da mesma moeda (Lloyd e Kossmann 2015).

Estudos demonstram que a degradação de amido nas folhas está conectada com temporização pelo relógio circadiano, sendo a taxa de degradação do amido podendo ser 
ajustada por uma "ampulheta" de $24 \mathrm{~h}$ que reinicia a contagem a cada ciclo de transição de escuro-para-claro, caracterizando um timer circadiano (Graf, et al. 2010).

Há também indicativo importante de necessidade de sensoriamento capaz de medir o amido nas folhas de forma rápida ao ponto de servir como sensor monitor de seu acúmulo e degradação, colaborando com aprimoramento de modelos de crescimento e simulação. Capturando pontos-chave do processo fisiológico de acumulação de amido que refletem diretamente no crescimento das plantas de trigo, foi proposto modelo de crescimento que utiliza acumulo de amido como parâmetro (Pan, Zhu e Cao 2007).

\subsection{Objetivo}

O objetivo principal do trabalho é obter através de uma abordagem metodológica, uma proposta de sistema de sensoriamento por processamento de imagem como ferramenta para quantificação qualitativa de amido nas folhas das plantas, realimentando sistema de controle de irrigação para de crescimento de plantas, otimizar o sistema de controle com um novo sensor e contribuir para influência do resultado de automação com controle em malha fechada do crescimento de plantas.

O enfoque do estudo está na comparação de métodos de extração e medição de amido em folhas de plantas com o método por análise de imagem proposto, observar as fases de modelos de comparação e correlação, da coleta de dados de entrada e análise, passando pela tradução do modelo, verificação e validação, conforme proposto por Chung (2004).

\subsection{Estrutura}

A estrutura do trabalho apresentado segue com uma introdução de aspectos biológicos de fisiologia e morfologia vegetal, especialmente sobre as folhas de plantas e seu papel na respiração, fotossíntese e desenvolvimento da planta e como possivelmente associar a medição da concentração de amido nas folhas como sensor em um sistema de controle em malha de crescimento de plantas.

Na primeira sessão há uma breve introdução e apresentação do trabalho proposto, seguido pela revisão bibliográfica apresentada na segunda sessão. 
Os materiais e métodos, do processamento de imagem e problema de contagem de estruturas são apresentados na terceira sessão onde métodos existentes são mostrados e associados ao problema observado.

Uma visão geral do modelo proposto aparece na sessão quarta deste trabalho com os resultados preliminares mostrados e relação com ciclo circadiano.

Por fim segue a proposta em si, com o detalhamento do procedimento seguido dos resultados e discussões. 


\section{Revisão Bibliográfica}

No reino vegetal, as plantas vasculares, que possuem tecidos condutores, xilema e floema, compostas por órgãos diferenciados ambos vegetativos e reprodutivos, formados por caule, raíz e folhas e que mais tarde incluem órgãos de esporos, sementes e frutos, evoluíram, colonizaram e dominaram como habitantes terrestres de nosso planeta, tanto que comumente fala-se de "terra das plantas", suprimindo outros habitantes como algas, fungos, musgos que compartilham do mesmo habitat (Bold 1967).

Quando pensamos em “terra das plantas”, do ponto de vista de produção de alimentos para a população humana, nos atemos e damos interesse maior aos cultivares domesticados, para tal, tentativas no sentido de aumentar a eficiência fotossintética devem resultar em aumento nas taxas de desenvolvimento de plantas e sua assimilação de carbono nas próximas décadas resultando em aumento de produtividade, entretanto, o entendimento da relação entre aumento de assimilação de carbono e crescimento da planta requer grande entendimento (Graf e Smith 2011). Ainda segundo Graf, há uma relação complexa entre fotossíntese e produtividade, bem como o controle pelo relógio circadiano sobre a taxa de degradação de amido, e novas descobertas jogam uma luz no controle de crescimento sob o ciclo claroescuro e suprimento otimizado de carbono.

Aumento de produtividade nas plantações vem sendo a prioridade nos estudos de amido (Lloyd e Kossmann 2015), que possui papel importante no crescimento das plantas, Smith em seu estudo (2012) analisou o comportamento do amido em folhas de Arabidopsis, como modelo de estudo utilizando marcadores de iodo como método de triagem e observação em microscopia óptica, julgou particularmente boa a utilização dessa espécie por possuir um curto ciclo de vida e mudanças de ciclo de luz muito pronunciados, além de alta concentração de amido nas folhas de suas rosetas. A Arabidopsis teve seu sequenciamento genético publicado e analisado (The Arabidopsis Genome Initiative* 2000) possibilitando o aprimoramento de estudos futuros com variações mutantes e correlações com abordagem genética permitindo identificação de algumas proteínas necessárias para síntese e degradação de amido e seu papel genético no metabolismo. 


\subsection{Estrutura da folha}

\subsubsection{A Célula Vegetal}

A célula vegetal consiste tipicamente em uma parede celular, mais ou menos rígida, e um protoplasto, unidade de protoplasma dentro da parede celular. O protoplasma consiste no citoplasma e no núcleo. O citoplasma inclui diferentes entidades envolvidas por membranas (organelas, como os plastídios), sistemas de membranas (como retículo endoplasmático) e estruturas não mebranosas (como ribossomos). O citoplasma é envolvido por uma única membrana chamada de membrana plasmática, que possui várias funções importantes como separar o protoplasto do ambiente externo, mediar transporte de substâncias, coordenar síntese e agrupamento da parede celular e detectar e facilitar as respostas aos sinais hormonais e ambientais relativos ao crescimento e diferenciação celular (Evert e Eichhorn 2014).

Diferentemente da maioria das células animais, as células vegetais possuem uma ou mais cavidades preenchidas frequentemente por líquidos chamadas vacúolos dentro do citoplasma que são envolvidos por uma única membrana denominada tonoplasto, como visto na figura (1) (Evert e Eichhorn 2014).

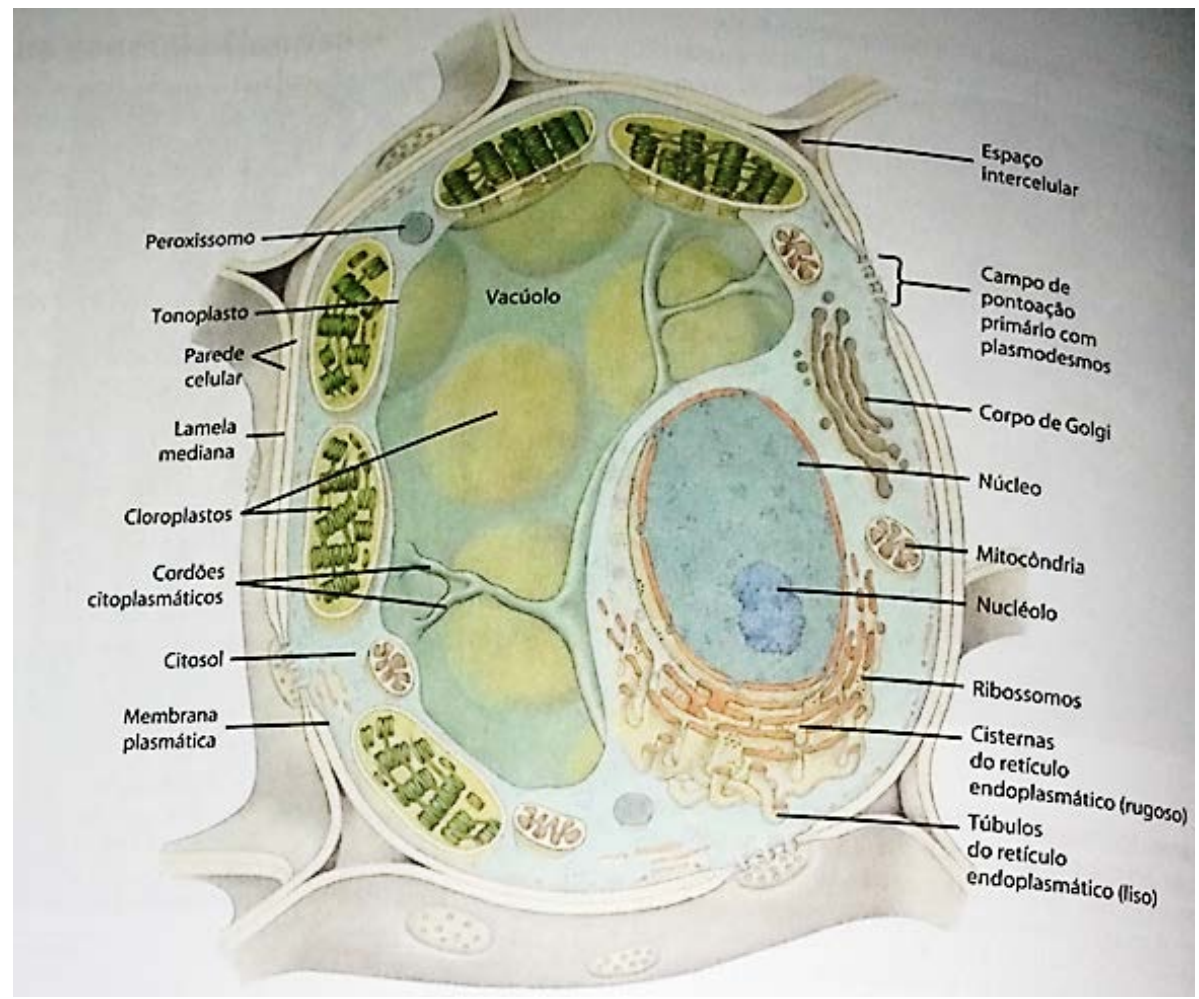

Figura 1 Representação esquemática de célula vegetal (Evert e Eichhorn 2014) 
Juntamente com vacúolos e parede celular, os plastídios são componentes característicos das células vegetais que estão relacionados com processo de armazenamento e fotossíntese, onde cada plastídio é envolvido por um envoltório que consiste de duas membranas, internamente diferenciado por um sistema de membranas em forma de sacos achatados chamados tilacoides e uma matriz mais ou menos homogênea denominada estroma, tendo como principais plastídios os cloroplastos, cromoplastos e leucoplastos (Evert e Eichhorn 2014).

Os cloroplastos são plastídios onde ocorre a fotossíntese e contêm pigmentos clorofilas e carotenoides. São encontrados nas plantas e algas verdes, medindo nas plantas entre 4 a 6 micrômetros em formato discoide, em concentração em uma única célula do mesofilo aproximadamente entre 40 e 50 cloroplastos, e em um milímetro quadrado de folha contém cerca de 500.000 já a parede celular, melhor do que qualquer outra característica diferencia a célula animal da vegetal. A parede limita a expansão do protoplasto, evitando a ruptura da membrana plasmática pelo aumento do protoplasto quando da entrada de água na célula (Evert e Eichhorn 2014).

\subsubsection{Estrutura da folha}

Todas as plantas vascularizadas, exceto seus ancestrais mais primitivos, são caracterizadas por possuir folhas, e podem ser classificadas em diversas categorias, diferenciadas por morfologia e anatomia. Todas as folhas compartilham muitas características em comum (Beck 2005).

Folhas surgem ontogeneticamente como emersão meristemática ou primordia na superfície de caules jovens, por várias camadas próximas da superfície, iniciada pela ativação de divisão celular provocando o surgimento da folha, que quando madura pode variar muito tanto em forma quanto em estrutura interna, e variar diferentemente para monocotiledôneas e dicotiledônias como visto na figura (2) (Bold 1967, Beck 2005). 

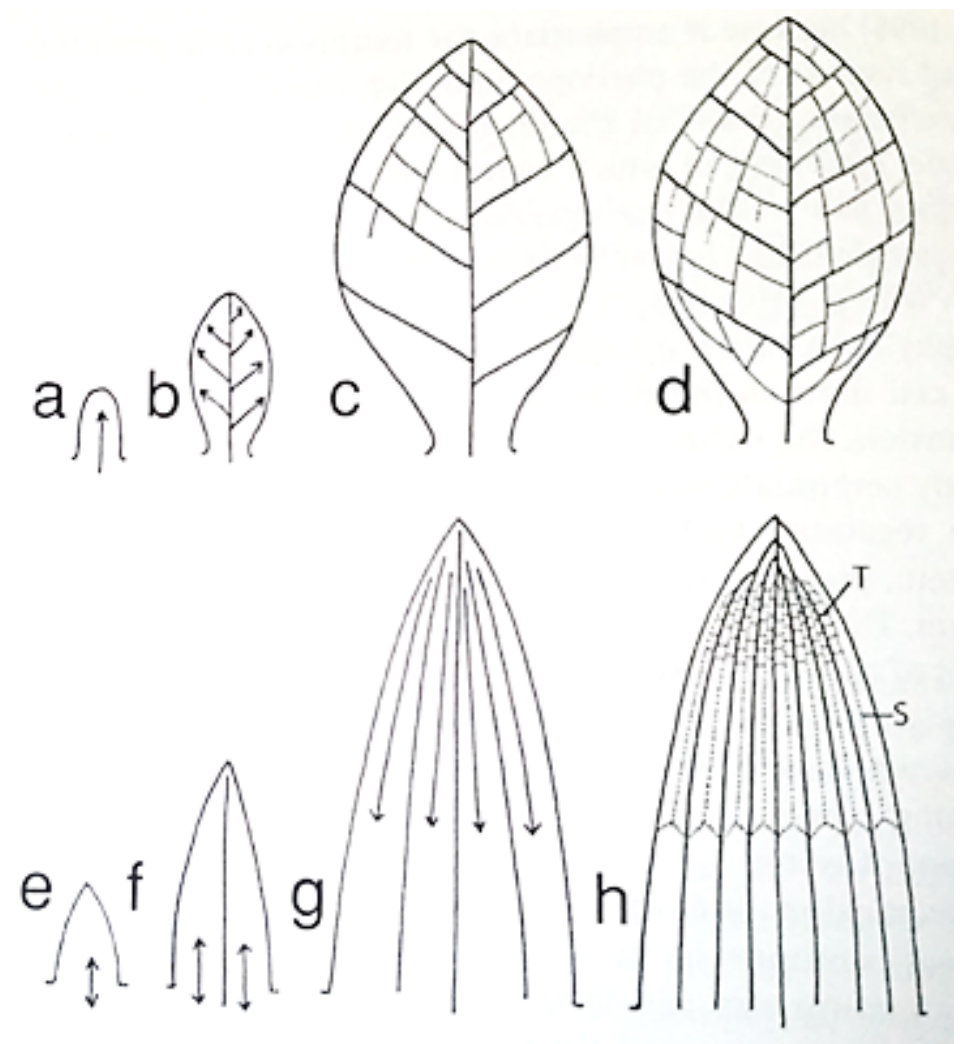

Figura 2 Padrão de vascularização em folhas; (a-d) Arabidopsis thaliana, exemplo de dicotiledônea; (e-h) Zea mays, exemplo de monocotiledônea (Beck 2005) - modificado

Histologicamente, a maioria das folhas é relativamente simples, cobertas por uma camada epiderme cutinizada, com estômato na parte inferior, superior ou em ambos os lados da epiderme, possuem internamente veias e células fotossintéticas do mesofilo, já comparando morfologicamente podem ser diferenciadas em duas categorias, folhas em plantas vasculares chamadas de microfilas e todas as outras folhas de outros grupos chamadas macrofilas cujas folhas usualmente possuem menor tamanho com única veia não ramificada em oposição as macrofilas com folhas largas ricamente de veias ramificadas (Bold 1967).

\subsubsection{Anatomia}

A anatomia da lâmina foliar é melhor observada em corte transversal figura (3), onde pode ser observado claramente as três regiões, epiderme, mesofilo e veias ou tecido feixes vasculares (Weier 1982). 

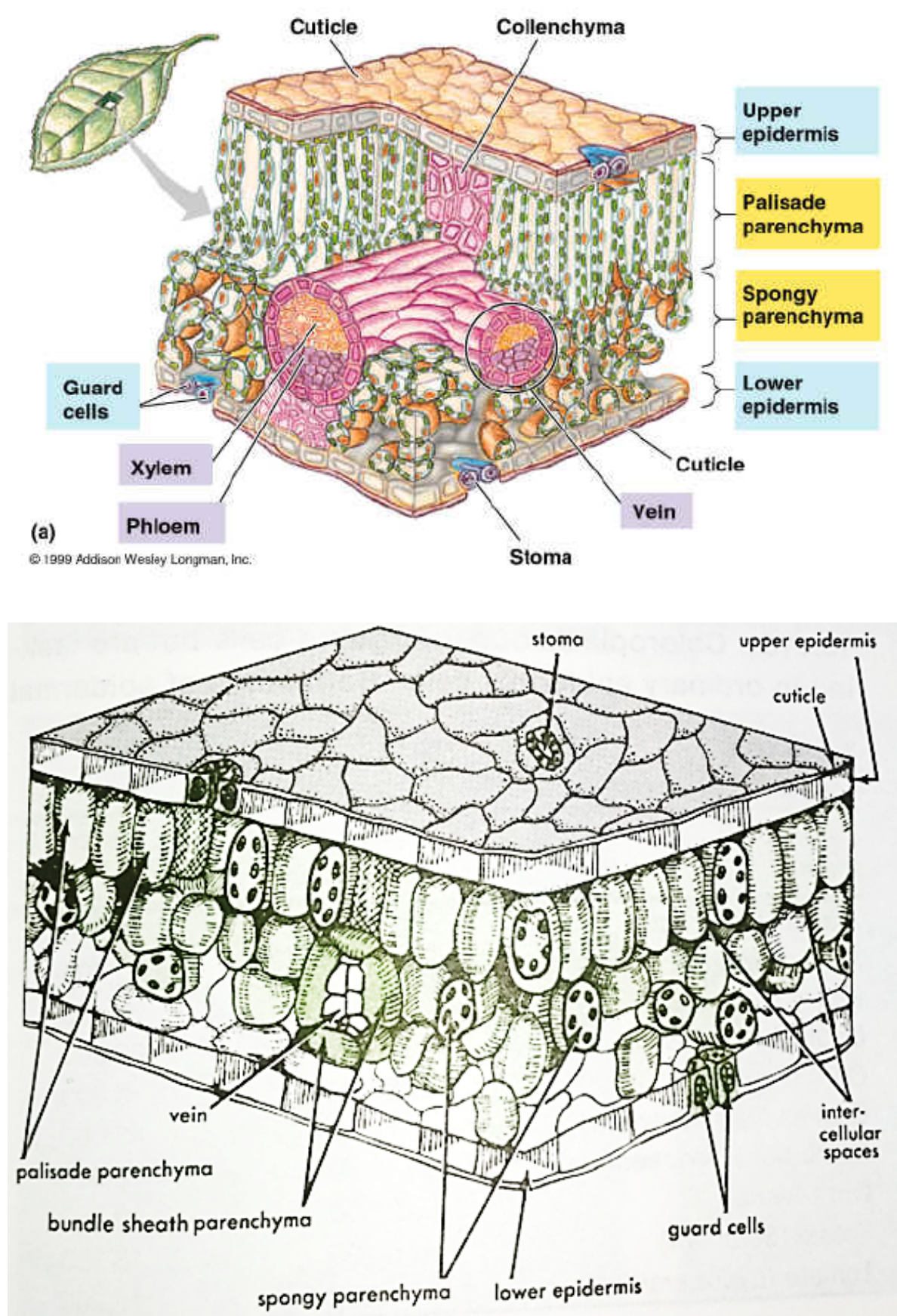

Figura 3 Representações tridimensionais de secção transversal de folha (Campbell, Reece e Mitchell. 1999, Weier 1982)

A epiderme usualmente consiste em uma camada de células que cobrem toda superfície da folha, podendo também possuir camada subepidérmica chamada hipoderme, protegendo-a contra ferimentos mecânicos e contra ressecamento. É composta por células epidérmicas comuns que variam amplamente em formato dependendo da espécie, mas geralmente é coberta por uma fina camada cuticular, mais grossa na epiderme superior do que na inferior, secretada por protoplastos e células guarda, um tipo especial de célula epidérmica, 
sempre ocorre em pares separadas por um poro, esse conjunto de duas células guarda com poro entre elas é chamada de estômato (Weier 1982).

A estrutura do parênquima, tecidos fundamentais constituintes dos órgãos vegetais, comparado ao tecido conjuntivo animal, pode ser diferenciado primeiramente pelo crescimento como elemento de diferenciação. Com origem meristemática as células parenquimáticas são largas em comprimento e diâmetro comparadas com células de outros tecidos em alguns micrometros de diferença (Buvat 1989).

Os tipos de parênquima possuem características inerentes aos plastídios que os compõem. Os conteúdos dos parênquimas é uma forma de sua diferenciação. Dentre os principais tipos de parênquimas, podem-se destacar o parênquima assimilatório ou clorofiliano, onde ocorrem principalmente fotossíntese, e o parênquima de armazenamento, onde fica armazenado excesso de material assimilado. Nas folhas o parênquima assimilatório constitui o mesofilo, podendo ser homogêneo ou heterogêneo em folhas cuja face superior é mais exposta à luz. A parte superior do mesofilo é diferenciada como parênquima paliçádico, composto por células mais adensadas e alongadas incluindo um alto número de cloroplastos, e a metade inferior do mesofilo é chamada de parênquima lacunoso ou esponjoso caracterizado por espaços intercelulares que facilitam a troca gasosa figura (4) (Buvat 1989).

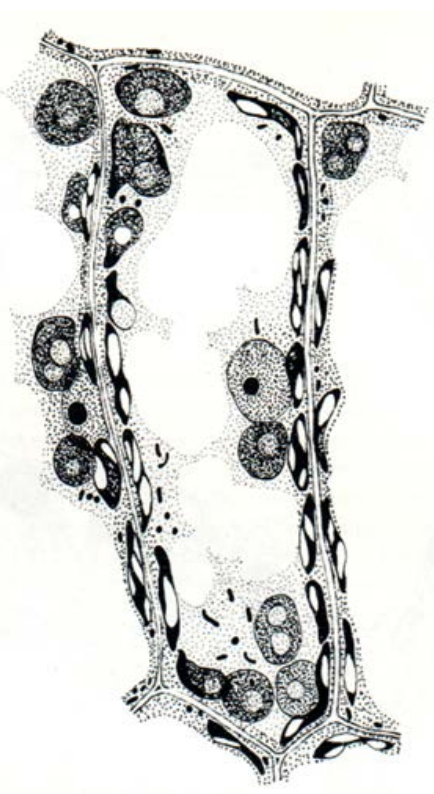

(a)

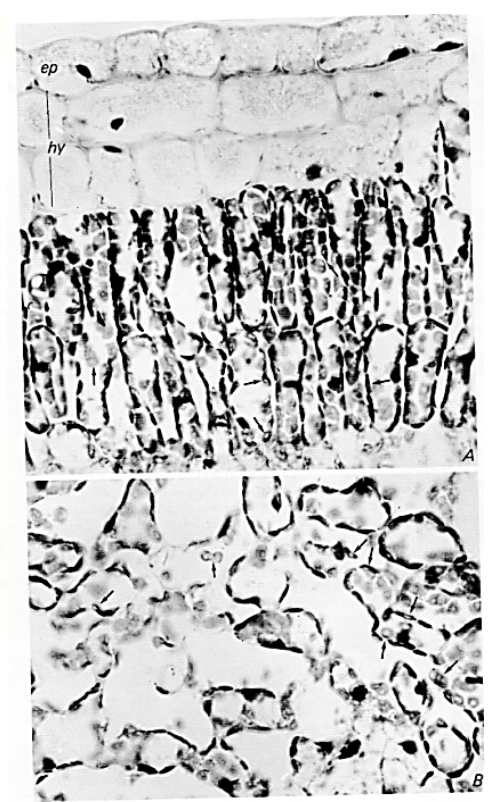

(b)

Figura 4 (a) Destaque de uma célula do parênquima paliçádico de uma folha. Nota-se grande quantidade de cloroplastos com grãos de amido. (b) Secção transversal de folha de Nerium oleander, destaque para uma camada de células epidérmicas, logo seguida por duas camas de células hipodérmicas, seguida do parênquima paliádico (parte superior do mesofilo) e parênquima esponjoso (parte inferior do mesofilo) (Buvat 1989) 


\subsubsection{Morfologia}

Podem existir folhas simples com lâminas não divididas, compostas com lâminas divididas, podem ligar-se ao eixo por pecíolo ou fixada diretamente e seu tecido vascular, chamado de veias. As veias podem ser ramificadas ou não ramificadas. Em muitas monocotiledôneas a vascularização é estriada e alongada, espalhada em intervalos delicadamente conectadas transversalmente, semelhante à estrutura de uma escada, em oposição ao mais comumente encontrada em plantas dicotiledôneas, cuja estrutura venal é reticulada, com veias abundantemente espalhadas, ramificadas em anastomose, existindo ainda tipos intermediários de estrutura venal como visto na figura (5) (Bold 1967, Beck 2005).

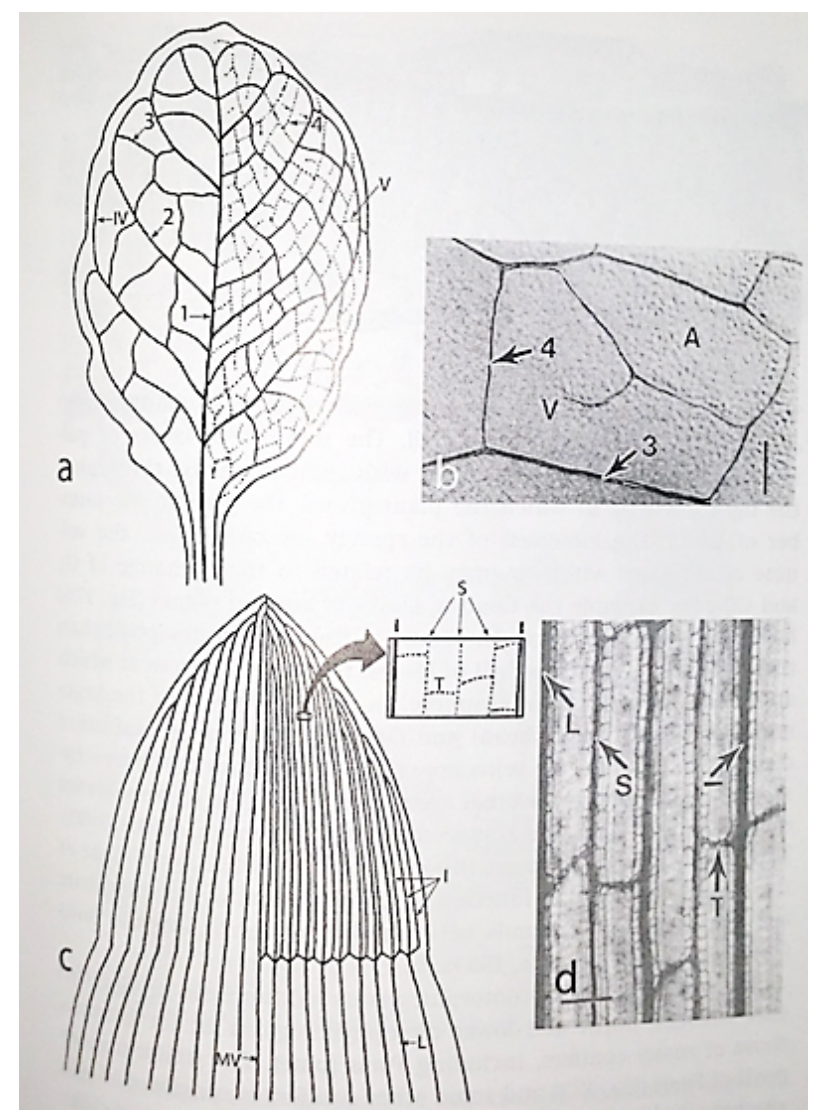

Figura 5 Padrão de vascularização em dicotiledôneas (a-b), com diferentes ordens de veias ramificadas, e monocotiledôdenas (c-b) com diferentes ordens de veias paralelas. (Beck 2005) 


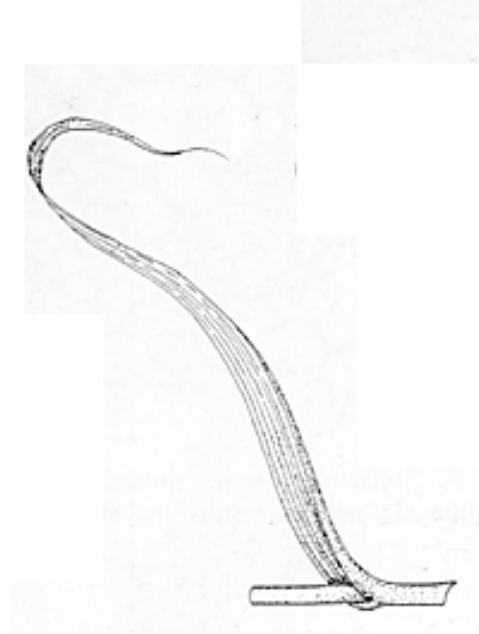

(a)

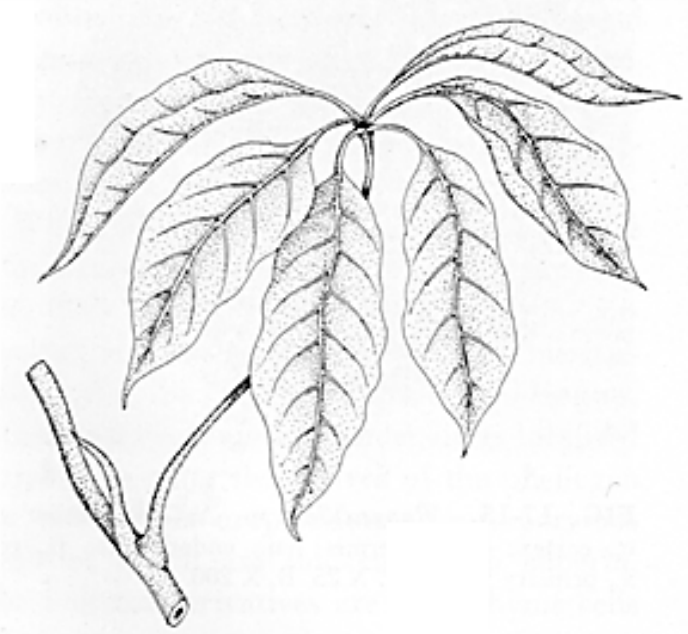

(b)

Figura 6 (a) Exemplo de folha simples de gramínea, (b) Exemplo de folha composta de Scheffeleria sp. (Bold 1967)

As folhas de plantas monocotiledôneas figura 6 (a) são, geralmente, ligeiramente diferentes das de dicotiledôneas figura 6 (b). As folhas de dicotiledôneas possuem em sua composição básica duas partes principais, o pecíolo e a lâmina foliar. Geralmente a lâmina é fina e expandida, coberta por uma rede de veias composta pelo tecido vascular, e que serve de suporte estrutural. Já as folhas de monocotiledôneas, como de algumas gramíneas, não possuem pecíolo diferenciado destacado. Ao contrário, a folha é dividida em duas partes, bainha e lâmina foliar. A lâmina normalmente é fina, com porção expandida geralmente de bainha larga, com a lâmina tendo sua base no caule, formando ou não um nó, e ligando-se ao caule por aurícula e lígula (Weier 1982).

Muitos outros aspectos morfológicos podem ser utilizados para diferenciação e classificação de folhas como forma, dependente do desenvolvimento da folha, simetria que varia muito o grau de simetria dentre as variados formatos de folhas, heteroblastia, dimorfismo, anisofilia, enrolamento ou ptyxis, dobramento, localização da estipula, modificação da estípula, espinhos, armadilhas para insetos, estruturas espinhosas emergentes superficialmente, suculência, e muitas outras formas morfológicas de diferenciação bem aprofundadas nos estudos de Bell (2008)

\subsubsection{Luz e controle do crescimento}

É surpreendente que as plantas verdes ao longo de sua evolução desenvolveram mecanismos para garantir posicionamento das folhas para maximizar a captura de luz, mas notavelmente esse processo é a variedade de elementos envolvendo controles biológicos e 
processos bioquímicos mediados pela luz nesse processo, sendo sensíveis à presença ou falta de luz, direção, duração do dia, intensidade, e composição espectral da luz no ambiente em que estão inseridas (Weier 1982). Analisando a estrutura interna observamos na figura (7) inclusive a orientação dos cloroplastos de acordo com a intensidade de luz recebida pela folha.

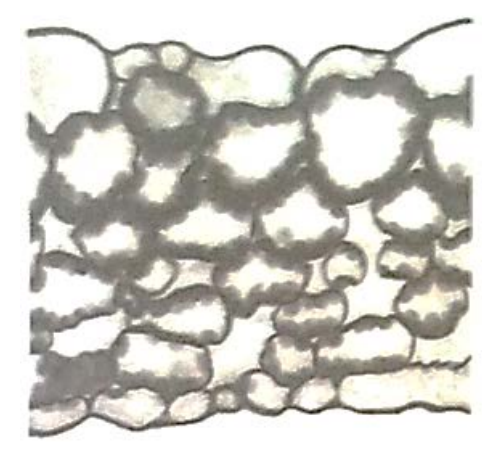

(a)

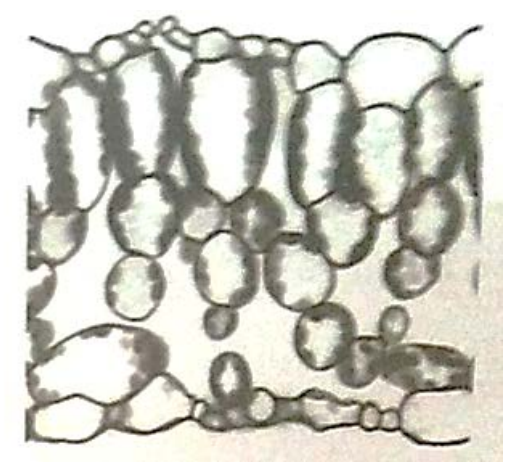

(b)

Figura 7 Orientação dos cloroplastos em (a) sob luz fraca, (b) sob luz forte (Evert e Eichhorn 2014)

Qualquer evento mediado por luz requer pigmento que absorva a luz de forma longa o suficiente para permitir a formação de um processo bioquímico na célula. Pigmentos são divididos em fotossintéticos, distribuídos em alta concentração e que conferem coloração aos tecidos da folha, e pigmentos de controle de crescimento, como o fitocromo, um pigmento encontrado universalmente em plantas vasculares, e a protoclorofila, um precursor imediato da clorofila. O fitocromo apresenta duas formas, uma mais instável ativa e outra mais estável inativa, absorvendo distintos comprimentos de onda de luz, funcionando como interruptor biológico, ativando e desativando reações, na forma inativa absorvendo vermelho distante (730nm) enquanto sua forma ativa absorve o vermelho (660nm). São usados para sentir se há ou não presença de luz e quando ativado pela luz participa do processo de desenvolvimento do modo de crescimento da planta superior. Pode inibir alongamento do caule, promover expansão foliar, e muitos outros eventos de desenvolvimento (Weier 1982).

\subsubsection{Fotossíntese}

Em plantas verdes e algas, em que a água serve como doador de elétrons, a equação completa da fotossíntese segue como na equação (1). Embora a glicose seja normalmente representada como carboidrato produzido na fotossíntese em equação simplificada, os primeiros carboidratos formados são trioses, monossacarídeos contendo três átomos de carbono (Evert e Eichhorn 2014). 


$$
3 \mathrm{CO}_{2}+6 \mathrm{H}_{2} \mathrm{O} \stackrel{\mathrm{LUZ}}{\longrightarrow} \mathrm{C}_{3} \mathrm{H}_{6} \mathrm{O}_{3}+3 \mathrm{O}_{2}+3 \mathrm{H}_{2} \mathrm{O}
$$

Eq. 1

Atualmente sabe-se que a fotossíntese ocorre em duas etapas e que de fato apenas uma delas requer luz, possuindo uma etapa dependente de luz e uma independente, em numerosas reações que ocorrem durante a fotossíntese, divididas em reações luminosas onde a energia luminosa é usada para formar ATP a partir do ADP e fosfato inorgânico e reduzir moléculas transportadoras de elétrons, e reações de fixação de carbono em que o dióxido de carbono é convertido em compostos orgânicos (Evert e Eichhorn 2014).

Dois fotossistemas estão envolvidos nas reações luminosas, sendo eles associados a um complexo de coleta de luz composto de moléculas de clorofila a e b, com carotenoides e proteínas de ligação de pigmentos, os dois tipos de fotossistemas, fotossistema I e fotossistema II, como visto na Figura (8), são ligados por uma cadeia transportadora de elétrons, em geral trabalham juntos, simultânea e conjuntamente (Evert e Eichhorn 2014).

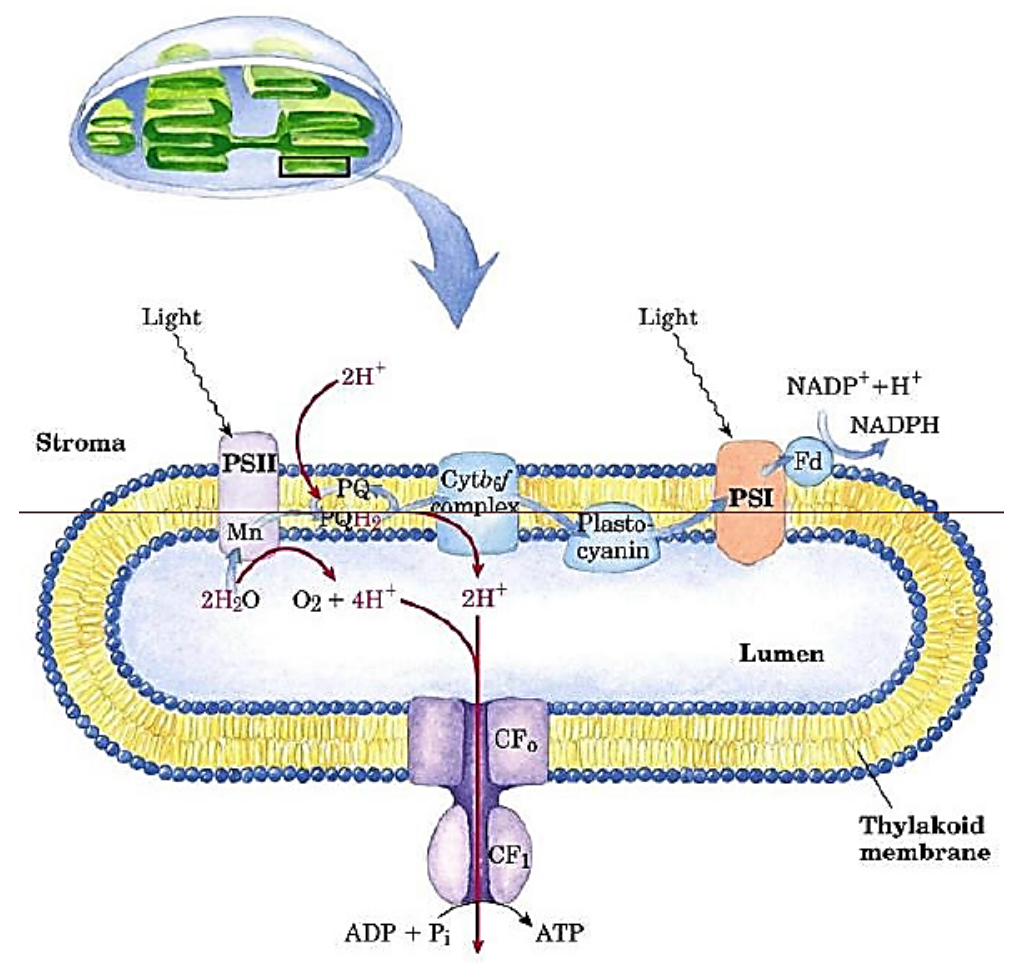

Figura 8 Fotossistemas I e II e atividade na membrana tilacóide do cloroplasto (LEHNINGER, NELSON e COX 1995)

As reações de fixação de carbono estão na segunda fase das reações de fotossíntese, Ciclo de Calvin, onde o ATP e o NADPH gerados pelas reações luminosas são usados para fixar e reduzir o carbono e assim sintetizar açúcares simples, embora a maior parte do carbono 
fixado seja transformado em sacarose ou amido, para transporte ou armazenamento das plantas (Evert e Eichhorn 2014).

Durante a fotossíntese, $\mathrm{CO}_{2}$ e fosfato inorgânico (Pi) são convertidos em triose-P que por sua vez é metabolizado primariamente em sacarose para transporte e utilizado para formação de tecidos dissipadores/dreno “sink tissues” (Gibson, et al. 2011). Uma porção da triose-P fica retida nos cloroplastos e é utilizada na síntese de amido, como observado na Figura (9).

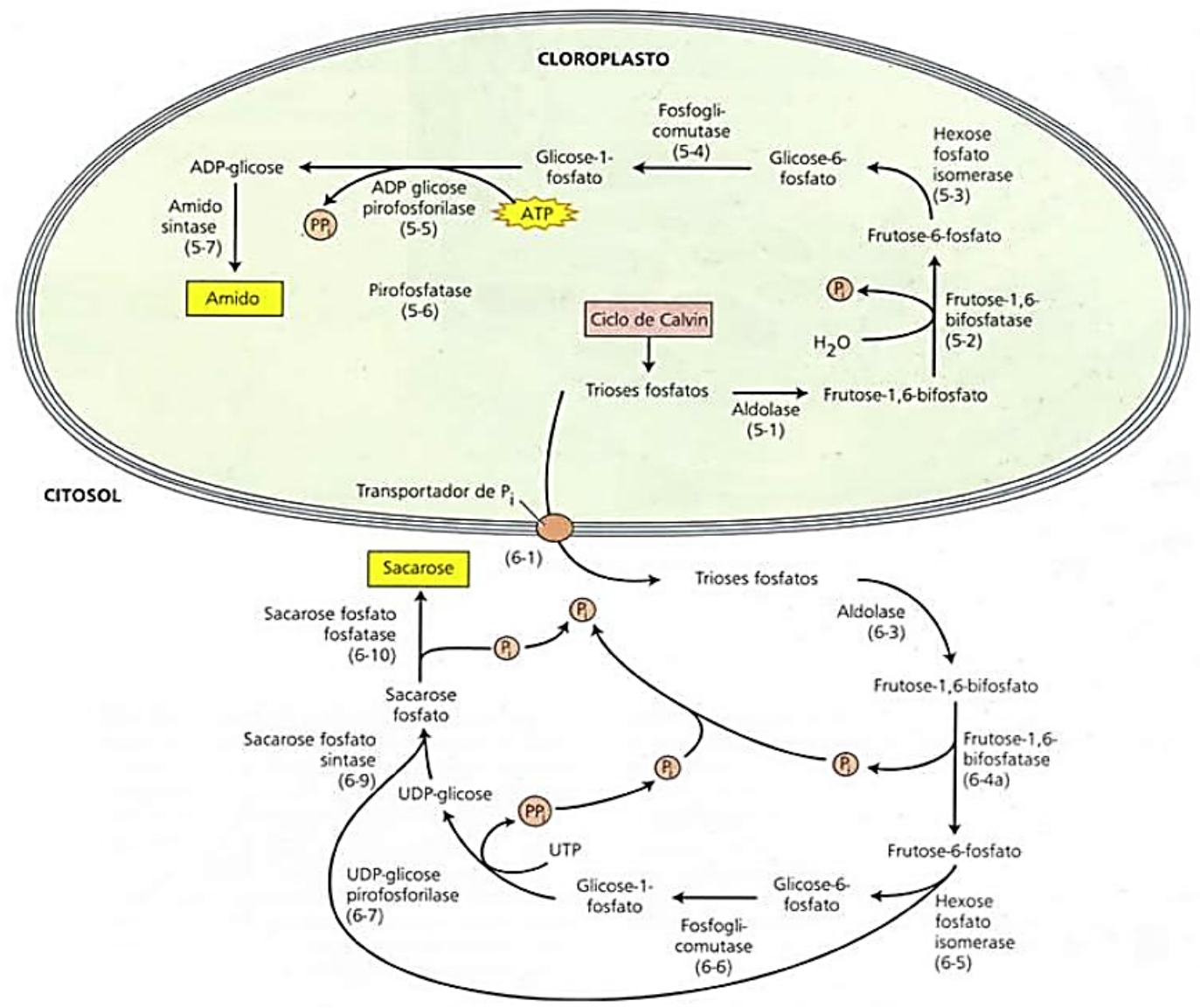

Figura 9 Síntese de Sacarose e Amido (TAIZ e ZEIGER 2002)

\subsubsection{Respiração}

As moléculas fornecedoras de energia são geralmente armazenadas na forma de sacarose ou amido. A respiração é a completa oxidação de açúcares e outras moléculas orgânicas a dióxido de carbono e água, necessitando de etapa preliminar de hidrólise de polissacarídios em glicose ou frutose, resultado dessa reação é a liberação de energia, a glicose pode ser quebrada de forma aeróbica ou anaeróbica, sendo que atinge seu rendimento máximo em condições aeróbicas cuja reação é mostrada na equação (2) (Evert e Eichhorn 2014). 


$$
\mathrm{C}_{6} \mathrm{H}_{12} \mathrm{O}_{6}+6 \mathrm{O}_{2} \rightarrow 6 \mathrm{CO}_{2}+6 \mathrm{H}_{2} \mathrm{O}+\text { Energia }
$$

Quando a glicose é oxidada em uma série de reações sequenciais catalisadas por enzimas, uma parte da energia é armazenada na forma de ligações fosfoanídricas terminais no ATP e o restante é perdido como calor, na glicólise a glicose é quebrada em piruvato, resulta na formação de duas moléculas de ATP e duas de NADH. Completa-se a quebra metabólica da glicose a dioxído de carbono pelo ciclo do ácido cítrico. O processo da respiração envolve a cadeia de transporte de elétrons e de enzimas inseridas na membrana interna da mitocôndria (Evert e Eichhorn 2014).

\subsubsection{Fotoperiodismo}

Fotoperíodo frequentemente fornece sinais temporizados para florescimento e outras atividades que preparam a planta para sobreviver à uma estação desfavorável ao crescimento, como formação de gemas dormentes resistentes a temperaturas de congelamento, turbérculos e bulbos, além de controlar florescimento por controle fotoperiódico envolvido na percepção do comprimento do dia pelas folhas, podendo ocorrer em plantas de dia curto ou plantas de dia longo, um exemplo pode ser observado na figura (10) que ilustra a resposta de plantas fotoperiodicamente sensíveis pela progressão de estações, com respectivas variações de durações de dia de acordo com a latitude. (Weier 1982). 


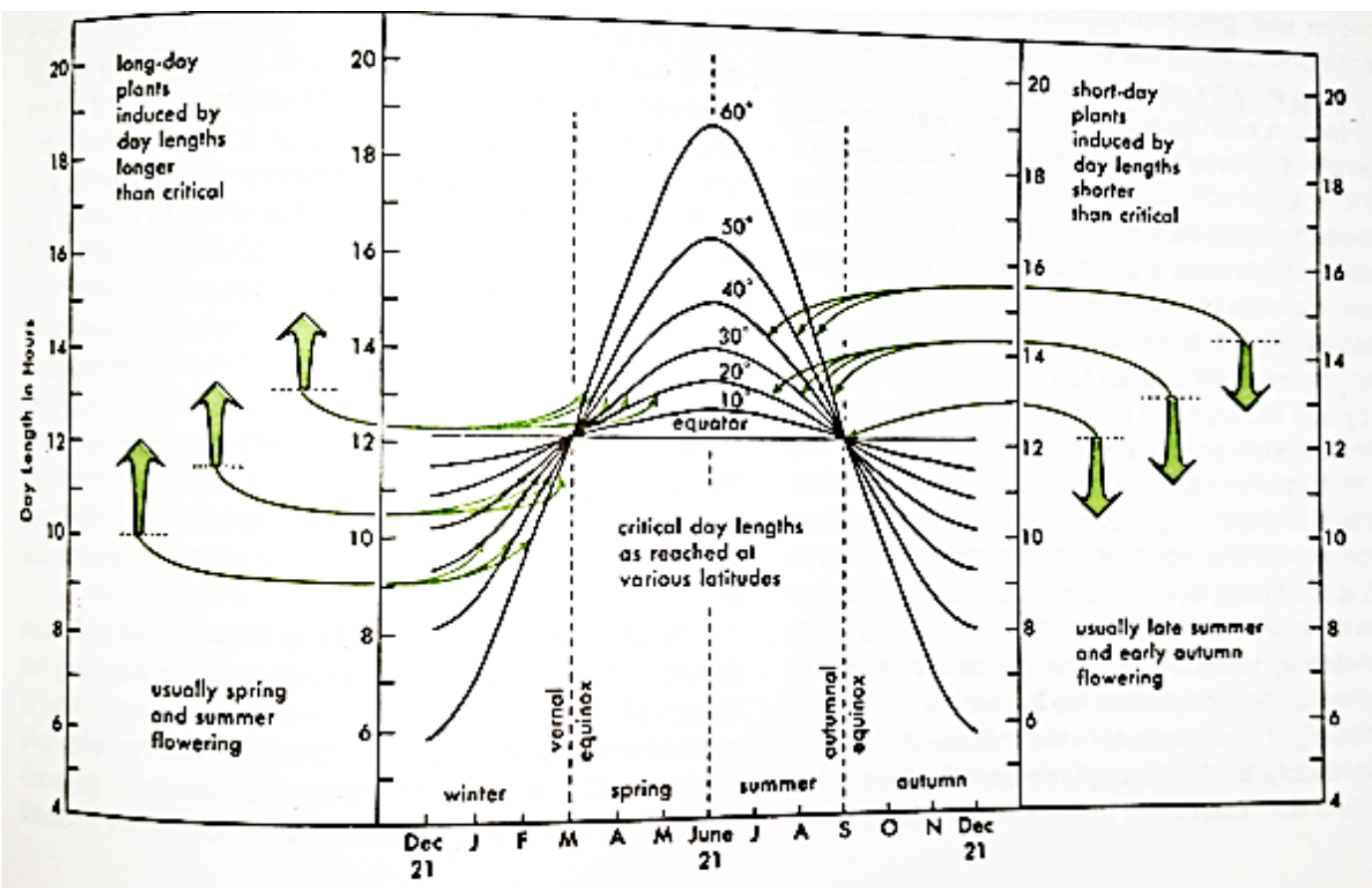

Figura 10 Diagrama ilustrando a resposta de plantas sensíveis fotoperiodicamente à progressão do dia ao longo das estações do ano, para diferentes latitudes (Weier 1982)

\subsubsection{Amido na estrutura foliar}

O potencial da análise de amido e sua compreensão necessitam de identificação dos postos-chave de seu papel e seu ciclo na estrutura foliar bem como também sua característica de composição e formação.

\subsubsection{Carboidratos}

Os carboidratos são as moléculas orgânicas mais abundantes na natureza e são principalmente moléculas armazenadoras de energia na maioria dos organismos vivos. Carboidratos simples são moléculas pequenas chamadas comumente de açúcares, são cristalinos e solúveis em água, representados por monossacarídeos, dissacarídeos e trissacarídeos (Evert e Eichhorn 2014).

Os monossacarídios funcionam como elementos constitutivos e fontes de energia; são blocos constitutivos, monômeros, a partir dos quais as células vivas constroem os dissacarídios, polissacarídios e outros carboidratos essenciais, sendo a glicose o monossacarídio mais importante, pois é a forma na qual o açúcar é transportado no sistema circulatório de animais vertebrados, além de principal fonte de energia química para plantas e animais. Já o dissacarídio sacarose é a forma de transporte do açúcar nas plantas, formado por 
dois monossacarídios, glicose e frutose, transportado desde as células fotossintetizantes onde é produzido para todas as demais partes das plantas (Evert e Eichhorn 2014).

Os polissacarídios funcionam como formas de armazenamento de energia ou componentes estruturais. São polímeros formados de monossacarídios interligados, formando longas cadeias, sendo o amido o principal polissacarídio de armazenamento e a celulose o principal polissacarídio de função estrutural (Evert e Eichhorn 2014).

\subsubsection{Amido}

Na maioria das plantas, os açúcares acumulados são armazenados como amido, o qual existe em duas formas: não ramificada (amilose) e ramificada (amilopectina) como observamos na figura (11) (Evert e Eichhorn 2014). A amilose e a amilopectina são armazenadas em forma de grão de amido insolúvel no interior dos cloroplastos e amiloplastos nas células vegetais, podendo ser quebrado em monossacarídios através de uma reação de hidrólise.

O primeiro passo na formação do grão de amido vem sendo debatido durante muitos anos, principalmente por não estar totalmente claro se o amido sintetiza poliglucanos, a priori espontaneamente a partir da ADP-glucose, ou se uma proteína separada é necessária para iniciar o processo de formação. Estudos recentes mostram que a proteína SS4 é essencial para a coordenação do processo de formação do grão de amido, mas quando o volume dos cloroplastos aumenta também o número de grãos formados aumentavam (Lloyd e Kossmann 2015, Crumpton-Taylor, et al. 2013).

A amilose praticamente não apresenta ramificações em sua estrutura, sendo que as unidades de glucose são conectadas por ligações glicosídicas do tipo $\alpha(1,4)$ e a porcentagem de remificações $\alpha(1,6)$ é menor do que $1 \%$. Já a amilopectina, uma das maiores biomoléculas conhecidas, é altamente ramificada, possuindo ligações tipo $\alpha(1,4)$ com proporção $5 \%$ de $\alpha(1,6)$, sendo que a composição e proporções de amilose e amilopectina variam dependendo da origem do amido (Amaral, et al. 2007). 

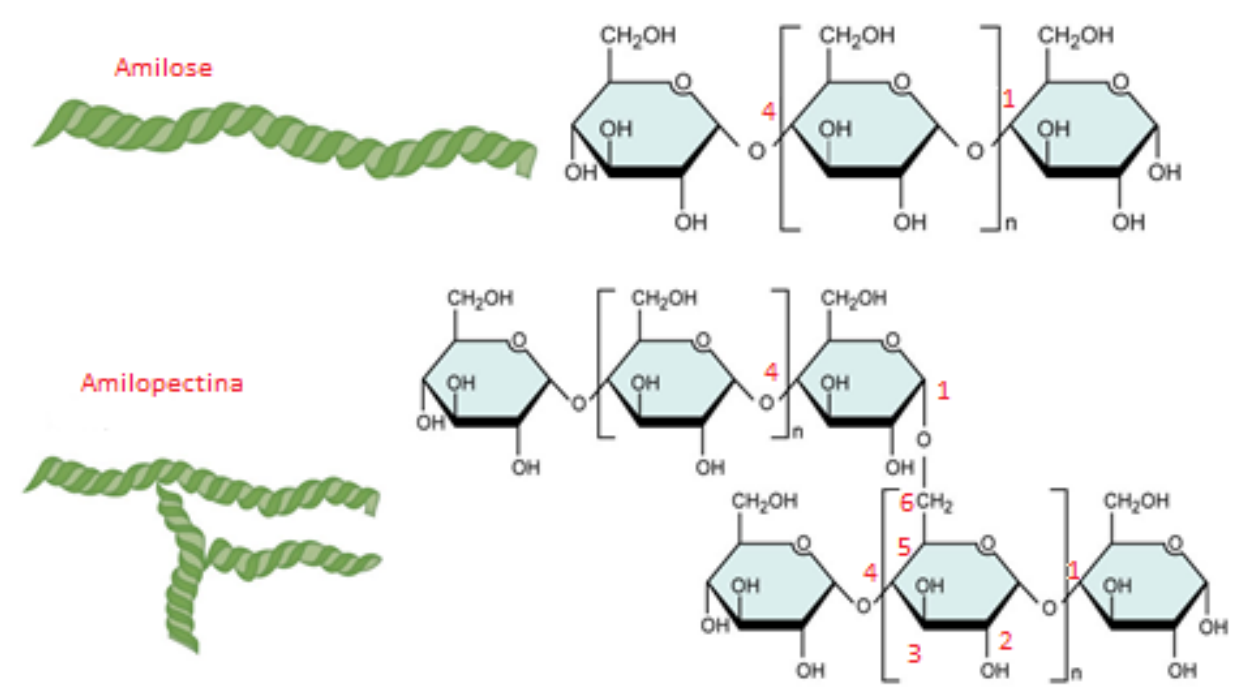

Figura 11 Estrutura da Amilose e Amilopectina, identificando as ligações tipo $\alpha(1,4)$ e $\alpha(1,6)$ (The Pennsylvania State University s.d.) - Modificado

\subsubsection{Ciclo do amido}

Em células vegetais, o amido é armazenado na forma de grânulos insolúveis em água que são localizados em organelas especiais. No caso das folhas, o amido é sintetizado e armazenado nos cloroplastos ou nos amiloplastos (Amaral, et al. 2007).

Estudos com linhagens transgênicas de Arabidopsis mostram uma significante correlação entre taxa de processamento de amido e área de folha, também que o aumento na biomassa e produtividade de sementes é tradução de capacidade aumentada devido aumento de reservas de carbono e energia transitórias como amido nas folhas servindo de fonte para crescimento noturno, da capacidade fotossintética aumentada pode-se aumentar o desenvolvimento dissipador desde que a fonte consiga controlar o metabolismo dissipador transitório (Gibson, et al. 2011).

\subsubsection{Papel do amido}

O crescimento das plantas é dependente do resultado líquido entre fixação e transporte do cloroplasto para regiões intracelulares e intercelulares de demanda fotossintética. Entretanto o resultado líquido do fluxo fotossintético advindo dos cloroplastos pode representar de $30 \%$ a $50 \%$ da taxa de fixação de $\mathrm{CO}_{2}$ devido aos grãos de amido formados a partir de fosfatos de açúcar recém formados, o que resulta em aumento na concentração de 
amido nas folhas durante o período de iluminação que representa de $10 \%$ a $30 \%$ do peso seco da lâmina da folha ao final de cada período luminoso fotossintético de cada dia (Chatterton e Silvius 1979).

Dados de estudos com Arabidopsis e arroz indicam que um aumento de grãos de amido nas folhas não só serve como um grande armazenamento transiente de energia para dar suporte heterotrófico de crescimento durante o período escuro como também aumenta a capacidade fotossintética da planta aliviando potencial realimentação devido a deficiência de Fosfato inorgânico (Pi) (Gibson, et al. 2011). Gibson sugere que o papel do amido nas folhas no aumento da capacidade fotossintética é bem observado no exemplo comparando forma selvagem de Arabidopsis com seus mutantes deficientes em amido ou mutantes sem amido, onde correlações significantes são obtidas entre taxa cumulativa de síntese de amido e crescimento da planta. Tais observações não só indicam que o amido nas folhas age como uma forma de reserva transitória de energia para consumo noturno dando suporte ao crescimento heterotrófico fora do período fotossintético, mas também como um produto final essencial na utilização de triose-P.

\subsection{Característica do ciclo circadiano para controle do amido}

O ciclo circadiano é um sistema de temporização de 24h endógeno, presente na maioria das plantas e animais. Mantém em cada indivíduo uma forma estimada de posição em relação a um ciclo de dia normal claro-escuro, dia-noite, sendo responsável por ditar a agenda de processos bioquímicos e fisiológicos para determinados períodos do dia (Graf e Smith 2011).

Estudos mostram que o mecanismo de temporização do relógio de controle de disponibilidade de carboidratos sugere fortemente ser função do ciclo circadiano, indicando vantagens evolutivas e um mecanismo sofisticado de predição e regulação de carbono disponível, dirigido pelo ciclo circadiano, tendo o amido acumulado e degradado praticamente de forma linear, com formato piramidal de ciclo dia-noite, (Graf e Smith 2011, Feugier e Satake 2014). Mas, os modelos propostos por Feugier e Satake indicam uma combinação do modelo linear com função de característica hiperbólica cumprindo importante papel no modelo de saturação $\beta(\mathrm{t})$, com sua peculiar taxa de degração de forma hiperbólica complementa o modelo com oscilação regulada proposto, como forma de solucionar o problema de administração de buffer de amido. 


\subsection{Métodos de Medição de Amido}

Potencialmente uma medição mais aprimorada torna-se útil para monitorar os produtos finais de fotossíntese, sacarose e amido, participantes da atividade fotossintética e da utilização do carbono fixado pela planta. Verificar os níveis desses produtos reflete observar a economia de carbono da planta, mas entre esses dois produtos, o amido é o candidato ideal por ser mais largo e mais estável que a sacarose (Edwards, Jolliffe e Ehret 2010).

Existem vários métodos para quantificação de amido descritos na literatura, cujas principais etapas de diferentes métodos residem em gelatinização (visando hidratação dos grânulos de amido), solubilização (ocorre pela quebra do polímero em fragmentos menores) e hidrólise de amido (quebra de amilose e amilopectina em glucose para detecção por métodos colorimétricos) (Amaral, et al. 2007).

\subsubsection{Métodos de extração e dosagem química}

Dentre os métodos químicos de dosagem de amido disponíveis na literatura, o de McCready (1950) é um dos mais conhecidos, amplamente utilizado no Brasil até a década de 70 devido sua precisão. Entretanto é extremamente trabalhoso e demorado e não adequado para medir tecidos vegetais que possuam outros polissacarídios além do amido, causando erro de leitura por superestimação da concentração de amido devido a aspectos metodológicos da utilização do ácido perclórico em hidrolisar outros polissacarídios da parede celular (Amaral, et al. 2007).

O método proposto por McCready (1950) consiste em etapas, iniciando com a solubilização do amido por ácido perclórico ou ácido sulfúrico para posterior quantificação por antrona ou por fenol seguido de ácido sulfúrico, seu protocolo completo pode ser verificado no trabalho publicado (McCready, et al. 1950).

\subsubsection{Método de extração química e dosagem enzimática}

Outros métodos químicos têm sido utilizados, em substituição ao método McCready, entretanto apenas para a parte de extração química, como o método desenvolvido por McRae (1971) e posteriormente otimizado por Haissig e Dickson (1979), que requer gelatinização do 
grânulo e utilização de glucoamilase, em processos demorados pois há muita espera entre etapas.

Normalmente, nos métodos enzimáticos, são utilizadas as enzimas amiloglucosidase ou $\alpha$-amilase, ou a combinação das duas, mas no método proposto por Amaral, et al (2007) há diferenciação e redução do tempo, primeiro a substituição da $\alpha$-amilase do fungo Aspergillus oryzae pela $\alpha$-amilase termoestável produzida pelo Bacillus licheniformis e sua adição concomitante ao processo de gelatinificação por ser termoestável suporta temperaturas mais elevadas, encurtando o tempo de processamento das amostras, utilizando enzimas altamente purificadas livres de contaminação de celulase e outras hidrolases que poderiam acatar outros polissacarídios senão o amido, alvo da medição, cujo protocolo está descrito no trabalho (Amaral, et al. 2007) que obteve ótimos resultados com economia de tempo e aumento de acurácia.

\subsubsection{Outras técnicas}

Mesmo o melhor e mais rápido método encontrado na literatura, (Amaral, et al. 2007), ainda possui problemas graves de utilização como sensoriamento e monitoramento de níveis de amido nas folhas das plantas em aplicação de automação e controle de malha fechada de crescimento de plantas, não só por serem todos métodos demasiadamente destrutivos, como também mesmo para pequenas amostras demoram no mínimo 72h entre a coleta da amostra e a obtenção da quantificação, com elevado custos procedurais e altos controles de descarte químico por trabalharem com ácidos controlados (perclórico), inviabilizando seu uso em automação.

Não foram encontradas na literatura outras técnicas de quantificação não destrutivas e que não sejam por processo de extração química ou enzimática e quantificação química ou enzimática de amido em folhas de plantas, entretanto cabe análise e verificação mais

aprofundada na literatura afim de garantir a não existência de técnicas de quantificação de amido em folhas de plantas que não envolvam processos destrutivos de quantificação química ou enzimática. 


\subsection{Processamento de Imagem}

O processamento de imagens abrange uma ampla escala de hardware, software e fundamentos teóricos, seguindo vários passos desde a aquisição da imagem até o resultado final obtido, podendo ser observados na figura (13) (Gonzalez e Woods 1992).

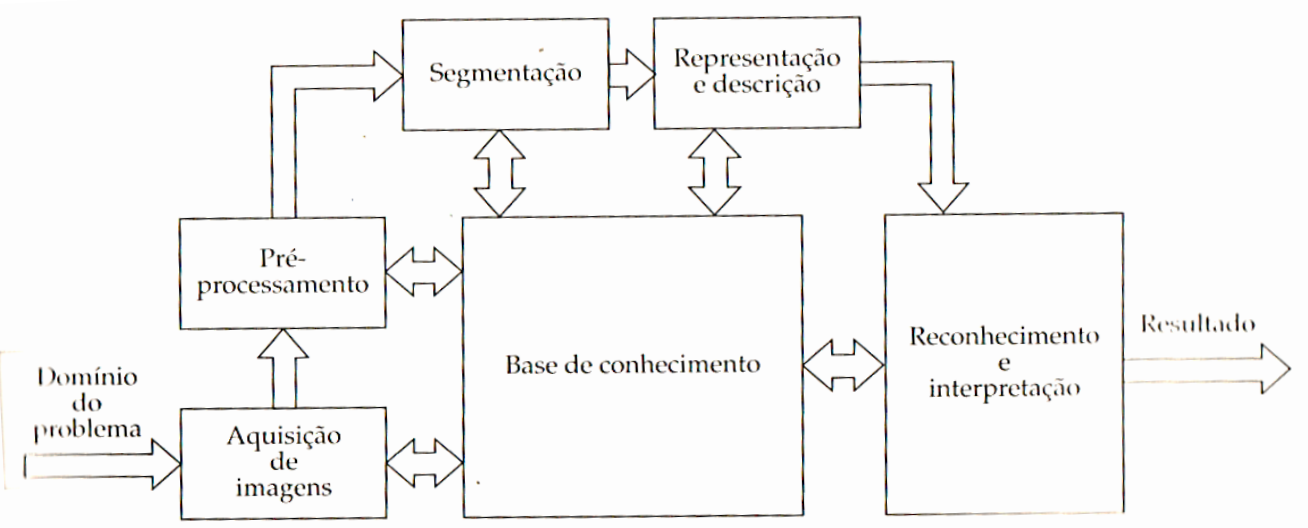

Figura 12 - Passos fundamental em processamento de imagens digitais (Gonzalez e Woods 1992).

\subsubsection{Pré-processamento de Imagem}

O modelo de mapa de cor RGB (Red-Green-Blue) é o mais comum, normalmente utilizado para armazenar imagens coloridas, amplamente utilizadas, mas sozinho pode não fornecer informações convenientes que colaborem de forma adequada para a segmentação de imagem, como visto em Barbedo (2014), que inicialmente visou identificar o melhor mapa de cor para destacar a estrutura das diferentes fases da vida da mosca-branca, observada na superfície de folhas de soja, facilitando pré-processamento e segmentação.

A utilização de diferentes mapas de cores para representação da mesma imagem, bem como representação de canais individualizados permitem inferir qual transformação deve ser utilizada antes do processo de segmentação, destacando objetos de interesse, como também visto em trabalhos recentes (Mahmood e Mansor 2012, Khan e Jaffar 2015, Xiang-yang, et al. 2015). 


\subsubsection{Problema de Segmentação}

A segmentação de imagem tem sido nos últimos 30 anos uma área extremamente ativa nas pesquisas relacionadas a processamento de imagem, com diversas abordagens propostas para solucionar o problema de segmentação, sendo o problema da segmentação de imagens e agrupamento permanecendo como um grande desafio para visão computacional (Xiang-yang, et al. 2015, Felzenszwalb e Huttenlocher 2004).

Algumas dessas soluções podem ser agrupadas em categorias, segundo Xiang-yang (2015):

“Elas podem ser divididas em seis categorias principais [2,3]: métodos baseados em limiar de histograma, métodos de detecção de borda, métodos baseados em regiões, métodos baseados em gráfos, métodos baseados em aprendizado de máquinas e métodos baseados em modelos estatísticos [4,5].”

\subsubsection{Métodos baseados em limiar de histograma}

Das soluções em segmentação mais relevantes, os métodos baseados em limiar de histograma são os mais amplamente utilizados quando se trata de imagens monocromáticas, pois torna-se simples identificar no histograma picos e vales correspondentes a regiões diferentes. Uma das maiores vantagens desses métodos é que não necessitam de conhecimento prévio a respeito do número de objetos na imagem, entretanto o desempenho desses métodos é ruim para imagens com histograma quase unimodal ou com região de interesse muito menor que o fundo da imagem (Xiang-yang, et al. 2015). Dos métodos mais consagrados, o proposto por Otsu (1979), onde sugere minimizar a soma ponderada das variações dentro da classe dos pixels de primeiro e segundo plano para estabelecer um limiar ótimo, tem sido largamente referenciado, produzindo resultados satisfatórios quando os números de pixels em cada classe estão próximos uns dos outros (Sezgin e Sankur 2004). 


\subsubsection{Métodos de detecção de borda}

Os métodos de detecção de borda partem do pressuposto de que cada pixel, quando na borda entre duas regiões, muda seu valor rapidamente. Os métodos de detecção de borda localizam basicamente os pixels correspondentes às bordas dos objetos de interesse (Xiangyang, et al. 2015). Wang e Oliensis (2010), consideraram de forma simplificada como problema da segmentação de primeiro e segundo plano de acordo com o brilho, resultando em imagem binária com pixels identificados. Os métodos de detecção de borda são normalmente aplicáveis a imagens com pouco ruído e simples, sendo pouco aplicáveis à imagens com várias bordas, em geral consumindo muito tempo de processamento na conversão de candidatos à borda em regiões de borda.

\subsubsection{Métodos baseados em regiões}

Os métodos baseados em regiões apoiam-se na ideia de que grupos de pixels podem ser formados, pois pixels adjacentes em uma mesma região devem possuir características semelhantes visuais, como cor, textura ou valor em escala de cinza (Xiang-yang, et al. 2015). Métodos baseados em regiões podem determinar a homogeneidade de objetos, enquanto incertezas na posição de fronteiras podem ser solucionadas com uma prévia detecção de borda, em combinação dos dois métodos (Mueller, Segl e Kaufmann 2004).

Os métodos são satisfatórios a depender da imagem de entrada, com especial sucesso para imagens com cenas simples resolvidas com técnicas locais simples, de grande uso também em combinação para detecção de variações em imagens em movimento, comparando quadros adjacentes, onde as regiões podem ser elementos de um modelo de malha ou formas arbitrárias com uma mesma cor ou textura uniforme, entretanto em cenas mais complexas pode não produzir segmentação satisfatória (Altunbasak, Eren e Tekalp 1998).

\subsubsection{Métodos baseados em grafos}

A abordagem dos métodos baseados em grafos consiste em considerar a imagem como grafos ponderados e conferir pesos, onde os nós representam pixels e o peso de cada borda conectando dois nós representam a similaridade entre eles (Xiang-yang, et al. 2015). Algumas abordagens usam uma grade na imagem para definir locais adjacentes entre pixels da imagem, 
medindo a diferença de intensidade ou cor, entre cada par de vizinhos, outras mapeiam os pixels da imagem para pontos em um espaço de características combinando a localização $(\mathrm{x}, \mathrm{y})$ e seu valor de cor (r,g,b) (Felzenszwalb e Huttenlocher 2004).

Ainda segundo Xiang-yang et al., os métodos são satisfatórios em converter a segmentação de imagem em uma estrutura otimizada, entretanto com complexidade de solução NP-Hard, e segundo Felzenzwalb e Huttenlocher essa complexidade ocorre em casos onde achar a segmentação da imagem cai em caso de limite não muito grosseiro e não muito fino, em um problema de endereçamento de borda entre duas regiões onde as medidas exigem mais do que uma única conexão antes da tomada de decisão quando não há nenhuma evidência a cerca da fronteira entre duas regiões.

\subsubsection{Métodos baseados em aprendizado de máquina}

Quando lidamos com imagens contendo fatores de perturbação, como ruídos, oclusões, partes faltantes, dados desordenados entre outros fatores que conferem complexidade à uma imagem, algum conhecimento prévio sobre a forma de alguns objetos é importante para solucionar ambiguidades durante o processo de segmentação (Etyngier, Segonne e Keriven, Shape Priors using Manifold Learning Techniques 2007).

O agrupamento é uma das formas mais antigas de aprendizado de máquinas, recentemente recebendo grande atenção no campo de segmentação de imagens, sendo a média K, a média-c Fuzzy (FCM) e a média hard-mean (HCM) eficientes técnicas de agrupamento utilizadas no particionamento da imagem em $\mathrm{K}$ agrupamentos com características comuns minimizando a variância entre pixels e centro do agrupamento, baseado em cores, intensidades, texturas e localização (Xiang-yang, et al. 2015).

Em imagens médicas, excluindo patologias não comuns, a forma geral da maioria das estruturas anatômicas macroscópicas é conhecida e prescrita pelo médico, no caso de segmentação de imagens em busca de terminados patógenos esse fato é facilitador, pois há conhecimento prévio de forma (Etyngier, Segonne e Keriven, Active-Contour-Based Image Segmentation using Machine Learning Techniques 2007).

Ainda segundo Xiang-yang (2015), é de grande valia utilizar esse tipo de método quando se requer informação prévia a cerca de um objeto em uma imagem a ser identificado e segmentado, e hoje avança na área de classificação como aprendizado de máquinas reduzindo o problema a uma classificação baseada em cores e texturas de determinadas características, entretanto problemas como segmentação exagerada devem ser levados em conta, pois os 
métodos de aprendizado de máquinas possuem qualidade superior em habilidade de segmentação, mas com custo computacional alto e resultados indesejados ocorrendo com frequência para determinados tipos de imagem sem correto conhecimento prévio de formas desejadas.

\subsubsection{Métodos baseados em modelos estatísticos}

Recentemente os modelos estatísticos tem recebido grande atenção na área de segmentação de imagem, com aumento do número de algoritmos propostos. A base dos algoritmos está na caracterização de valores de pixels como modelo estatístico, sendo a soma ponderada de componentes finitos, cada componente modelando a distribuição dos pixels de uma região e cada peso representando a probabilidade inicial da região correspondente (Xiang-yang, et al. 2015).

Quando considerada a abordagem de métodos baseados em modelos estatísticos, com segmentação Bayesiana, geralmente é adotado o modelamento de campos aleatórios de Markov. O problema estatístico vem da "perda de dados”, com parâmetros estimados a partir de variáveis aleatórias cuja distribuição é uma mistura de distribuições (Pieczynski 1992).

A principal vantagem dos modelos estatísticos é utilizar o conhecimento a priori para modelar a incerteza de maneira probabilística, além de fornecer uma maneira natural de agrupamento de dados baseado nos componentes da mistura que os geraram. Apesar de popular e dominante, os métodos que utilizam campos aleatórios de Markov para elaborar seus algoritmos comumente produzem resultados indesejados (Xiang-yang, et al. 2015). 


\section{Materiais e Métodos}

Para parte inicial do trabalho, plantas de sorgo Sorghum bicolor variedade SORGO VAR BRS 330 EMBRAPA Sete Lagoas MG ano 2012 foram cultivadas em casa de vegetação, em vasos individuais de 141 em meio inerte vermiculita, germinadas em 17 de junho de 2014 na região de Santana de Parnaíba-SP, com regas diárias noturnas. As condições no dia da coleta em 17 de agosto, nascer do sol as $06 \mathrm{~h} 31$ e por do sol as $17 \mathrm{~h} 52$, temperatura variando de $18^{\circ} \mathrm{C}$ a $28^{\circ} \mathrm{C}$ e humidade relativa variando entre $43 \%$ e $53 \%$, medidos com sensor DHT11e registrados com placa de aquisição Arduino UNO R3.

Amostras uniformes foram retiradas em intervalos de 3h, com início as 0h00 do dia 17 até as 0 h00 do dia 18, duas retiradas da folha 5 e duas retiradas da folha 7, em formato de discos de diâmetro $1,7 \mathrm{~cm}$, imediatamente congeladas e armazenadas a $-20^{\circ} \mathrm{C}$, posteriormente tendo seu amido extraído e quantificado conforme protocolo descrito em (Amaral, et al. 2007), para obter um resultado inicial qualitativo sobre o comportamento do acúmulo de amido nas folhas ao longo do dia, cujo resultado segue na figura (13), em que podem ser observadas as séries representando cada conjunto amostrado, series 1 e 2 para amostras da folha 5 e séries 3 e 4 para amostras da folha 7.

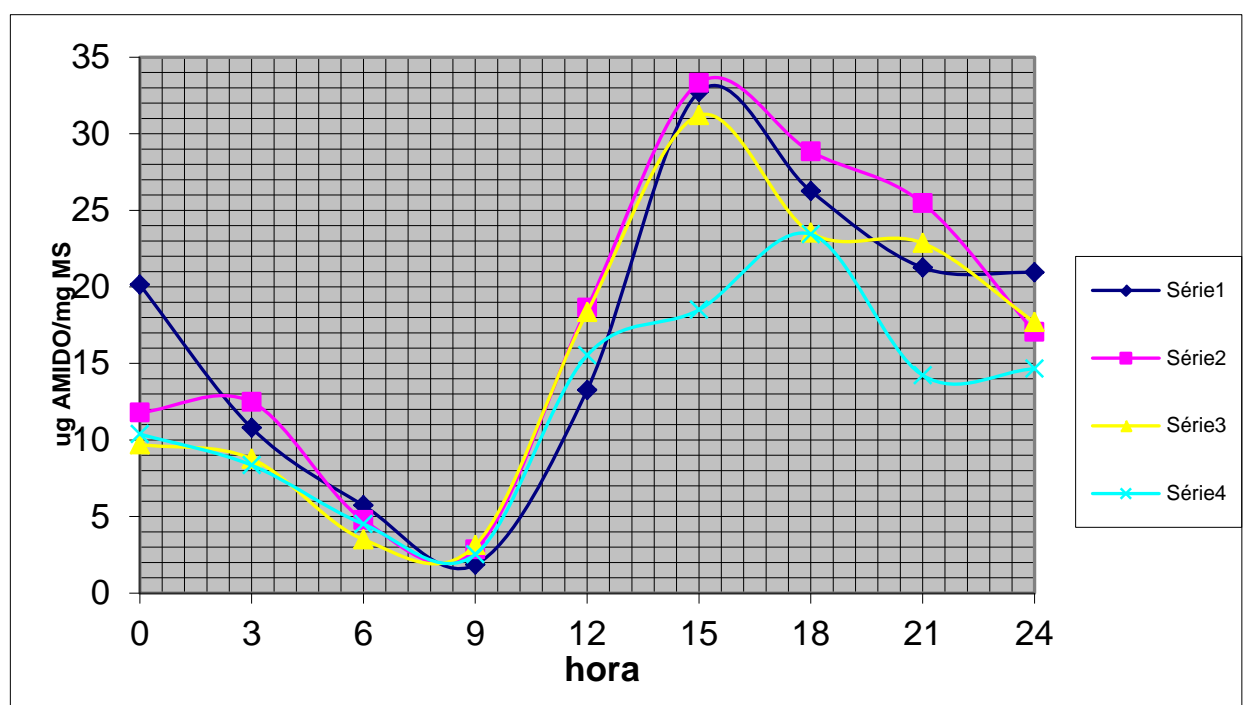

Figura 13 - Curvas de sintese e degradação da quantidade de amido nas folha de sorgo ( $\mu$ g AMIDO/mg Massa Seca)

O resultado obtido pode confirmar qualitativamente a característica de síntese, acúmulo e degradação de amido encontrado em literatura sobre o papel do amido nas folhas.

Novas coletas foram realizadas em 17 de maio de 2015, nascer do sol 6 h35 e por do sol 17h32, já com o intuito de obter imagem de secção transversal de folha de sorgo, seguiu- 
se o mesmo processo de cultivo e retirada de amostras de folhas de plantas de sorgo da mesma variedade, germinadas em 17 de março de 2015, com a retirada de mais duas amostras por período imediatamente fixadas em fixador FAA50, posteriormente lavadas em etanol 50\%, duas lavagens 10min, depois passadas para etanol 70\% e assim mantidas até o corte.

Foram feitos cortes utilizando micrótomo de congelamento do laboratório de anatomia vegetal do IB-USP (MICROM KS 34 Thermo Scientific, LEICA SM2000R), com espessura de $20 \mu \mathrm{m}$ (aproximadamente duas camadas de células), montadas em lâminas com solução de iodo lugol 2\%, e observadas com aumento de 40x em microscópio de luz (LEICA DMLB), imagens obtidas com câmera acoplada ao microscópio (LEICA DFC310 FX), cujo melhor resultado obtido para visualização de grãos de amido pode ser observado na figura (14).

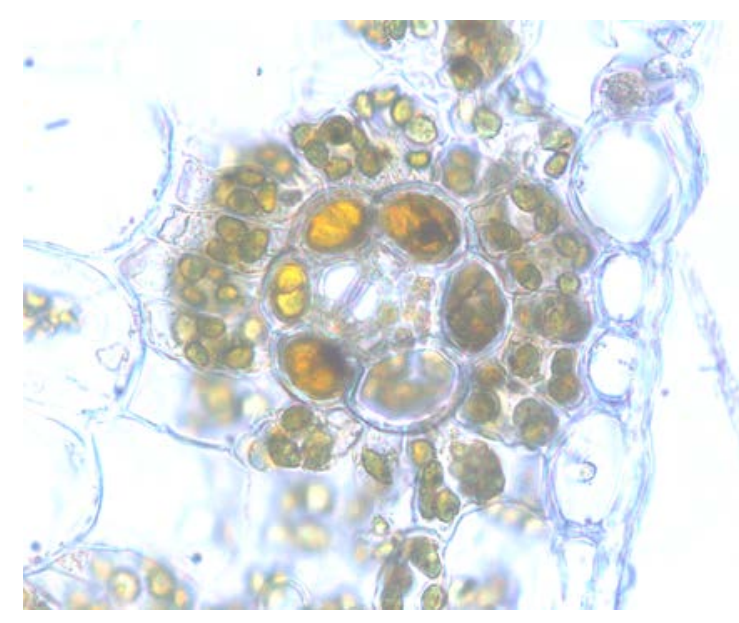

Figura 14 Sorgo, marcado Lugol 2\%,

Como observado, resultado não demonstrou evidencias satisfatórias para contraste com relação à quantidade e tamanhos de grãos de amido, levando a uma suspeita com relação à observação em folhas de monocotiledôneas da família das gramíneas. Amostras de folhas de cana-de-açúcar jovem cedidas pelo laboratório LAFIECO-IB-USP foram analisadas, corte fresco de amostras coletadas às $12 \mathrm{~h}$ e às $16 \mathrm{~h}$ do dia 21 de maio de 2015, utilizando mesmo micrótomo de congelamento para corte com espessura de $20 \mu \mathrm{m}$, limpeza de pigmentos com solução de hipoclorito de sódio $2 \%$, diluído $50 \%$, com posterior marcação com lugol $2 \%$, como visto na figura (15), também sem muito contraste para grãos de amido marcados. 


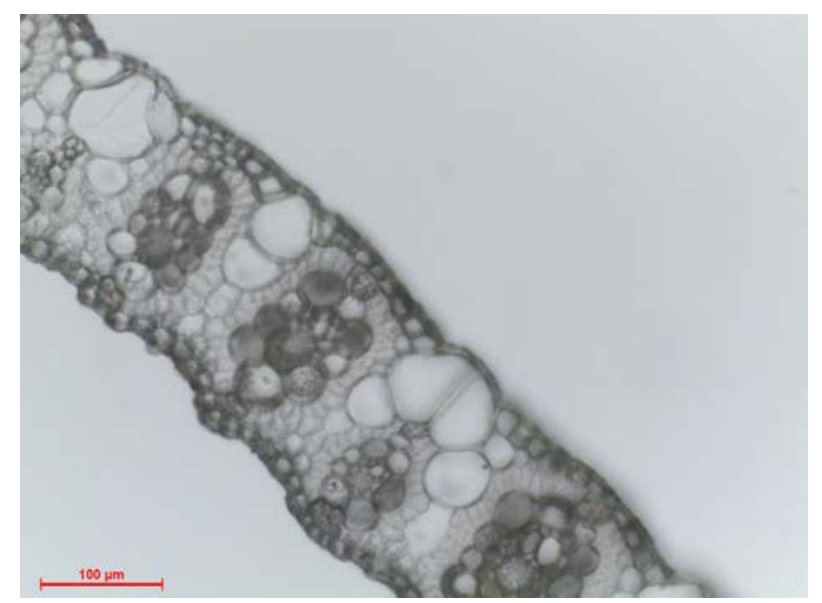

Figura 15 cana-de-açúcar, marcador lugol, remoção de pigmentos solução hipoclorito de sódio 1\%

Seguiu-se então com abordagem de obtenção de imagens de dicotiledôneas, para tal amostras de folha de goiabeira Psidium guajava $L$ de aproximadamente 20 anos de idade, localizada em Santana de Parnaíba (coordenadas geográficas -23.449788, -46.875508), coletadas em 5 diferentes horários no dia 6 de junho de 2015, nascer do sol 6h44 por do sol 17h28, com amostras em discos padronizados igualmente às de sorgo, separadas em amostras para extração e quantificação (ainda não realizada) e amostras imediatamente fixadas em fixador FAA50 seguindo mesmo procedimento de lavagem e armazenagem de material. Posteriormente foram montadas 5 lâminas com diferentes cortes de secção transversal, uma para cada horário, com limpeza por solução de hipoclorito e marcação com marcador solução de lugol 2\%, identificas como C1 (0h00), C2(7h00), C3(12h00), C4(15h00) e C5(18h00), como observado na figura (15 goiaba).

Ao contrário da observação em folhas de monocotiledôneas, nas folhas da goiabeira Psidium guajava $L$ observamos ampla variação de contraste e grande diferença em horários diferentes, cujos resultados preliminares serão discutidos adiante na sessão 4.2.

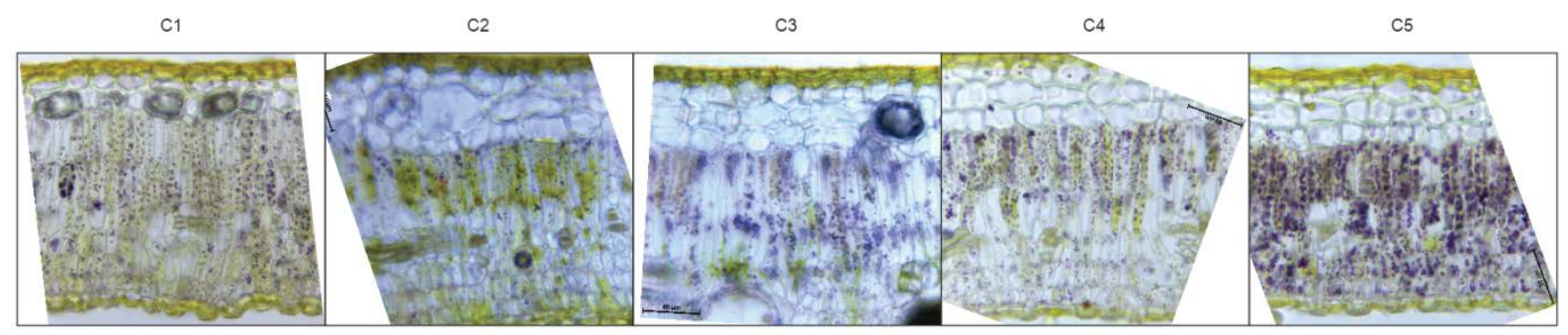

Figura 16 - Secção transversal de folha de goiabeira Psidium guajava L, coletadas em diferentes horários. C1 (0h00), C2(7h00), C3(12h00), C4(15h00) e C5(18h00). 


\subsection{Aquisição de Imagem}

Para escolha de abordagem na aquisição de imagem, inicialmente comparamos dois métodos, Microscopia de Luz (ML) e Microscopia Eletrônica de Transmissão (MET) para obtenção de imagem de corte em secção transversal de uma folha observando grãos de amido.

Como observamos na figura (17) em aumento de 33000x (MET) uma imagem de folha de Avena Ventricosa destacando um cloroplasto com grão de amido e demais detalhes finos como membranas e ribossomos no estroma (Gunning e Steer 1975).

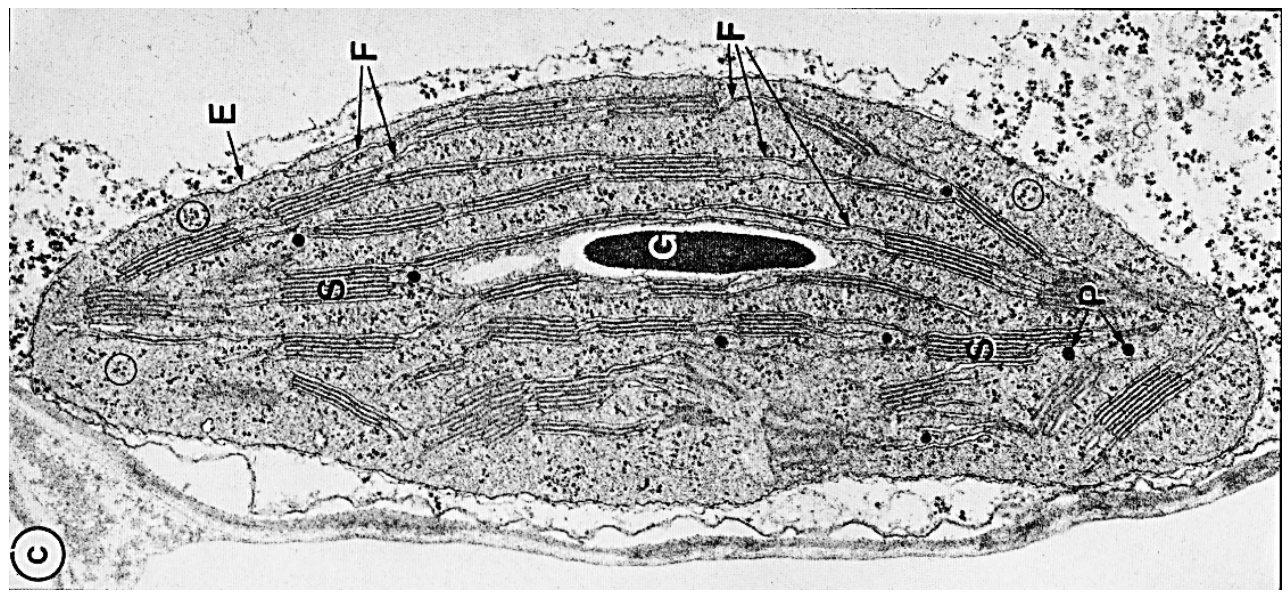

Figura 17 - Corte Avena ventricosa em destaque para Cloroplasto em MET aumento 33.000x, (E) membranas de envelopamento do cloroplasto, (S) vista lateral das granas, ribossomos densamente observados e circulados dentro do estroma, (G) grão de amido, (F) sistema de membranas interconectando as granas (Gunning e Steer 1975).

Observamos na figura (18), em aumentos de lente objetiva 10x, 20x, 40x e 100x (ML), uma imagem de folha de Psidium guajava $L$, amostra coletada às 18h fixada em FAA50, marcador solução de lugol $2 \%$, espessura do corte $10 \mu$ m, onde se destacam os grãos de amido das demais estruturas e componentes da folha, evidentemente contrastados. 


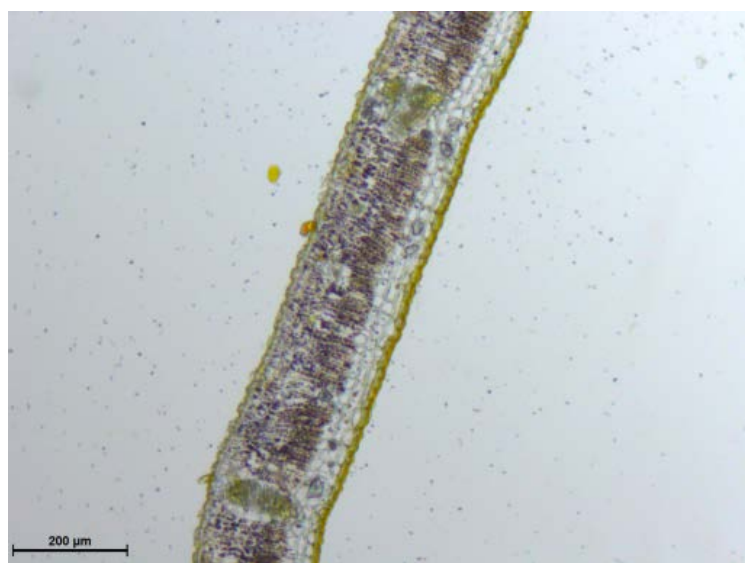

(a)

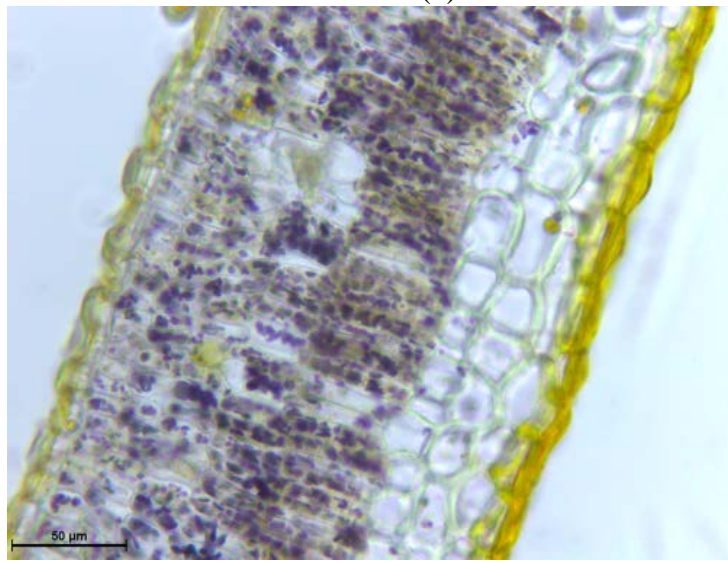

(c)

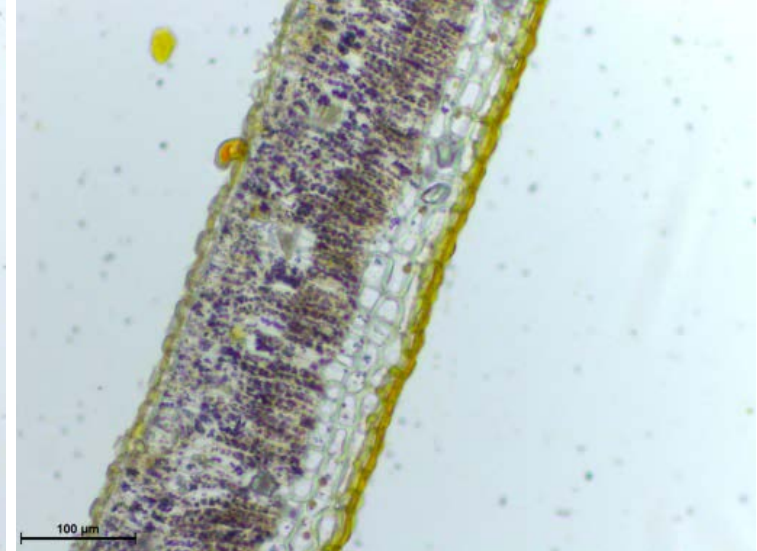

(b)

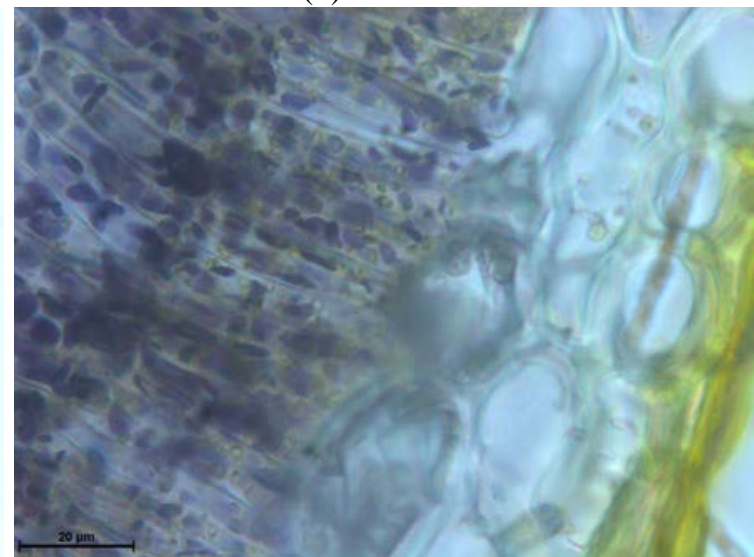

(d)

Figura 18 imagem de folha de Psidium guajava L em aumentos de lente objetiva (a)10x,(b) 20x,(c) 40x e (d) 100x (ML), espessura de corte 10 $\mu \mathrm{m}$, marcador lugol, fixador FAA50, coletada 18h.

O nível de detalhamento obtido por MET é demasiadamente especifico para uma organela de uma única célula de um corte extremamente fino da folha, ao passo que uma maior cobertura da secção transversal com maior área de observação e com cortes mais espessos $10 \mu \mathrm{m}$, aproximadamente uma camada de células intactas, permite observar com mínimo de clareza utilizando marcador solução de iodo lugol, os grãos de amido evidentemente destacados em uma técnica de microscopia mais simples e mais barata de obtenção de imagem.

Para escolha de abordagem na aquisição de imagem, seguiremos então imagens obtidas com Microscopia de Luz (ML) em detrimento das obtidas com Microscopia Eletrônica de Transmissão (MET) para cortes em secção transversal de uma folha observando grãos de amido destacados com marcador solução de lugol 2\%, uma vez que a formação de coloração diferenciada pela interação entre amido e soluções de iodo torna-se importante ferramenta para caracterização de amido e sua presença na estrutura da folha (Santacruz, Andersson e Aman 2005). 


\section{Abordagem inicial}

No projeto apresentado obtemos uma imagem em microscopia de luz de amostra da secção transversal de folha de planta, coletada em diferentes intervalos de tempo ao longo do dia. Por tratamento convencional, utilizamos o método de extração e quantificação de amido descrito em (Amaral, et al. 2007) como valor real de quantidade de amido de uma determinada amostra, comparamos com o modelo obtido por processamento de imagem, avaliam-se as diferentes possibilidades para abordagem desse problema com possível comparação e validação, para futuro uso como efetivo sensor em sistema de controle em malha fechada para crescimento de plantas.

\subsection{Abordagem por contagem de estruturas}

Após identificar que os grãos de amido observados ao longo do dia, variam tanto em tamanho quanto em quantidade, figuras (19) a (23), mas ficando bem destacados na imagem, mantendo formato aproximado de objeto ovalado, com algumas sobreposições, podemos utilizar uma abordagem para segmentação que busque isolar os objetos para posterior identificação de estruturas e contagem de população de grãos, com classificação de tamanhos, semelhante à abordagens de quantificação de células vermelhas de sangue, em analogia ao aplicado em tecidos animais, utilizando para tal a Transformada de Hough (Mahmood e Mansor 2012), dada tal abordagem, pode-se estimar o número de grãos de amido por área de secção transversal de uma folha, bem como o diâmetro médio dos grãos.

\subsection{Abordagem por área e cor}

Como observado nas figuras (19) a (23), as imagens obtidas possuem certa complexidade para uma correta segmentação, com baixo erro e poucos artefatos indesejados. A contagem de estruturas pode fornecer informações pertinentes na elaboração de modelo para quantidade de amido nas folhas, correlacionando-o com quantificação adotada como real pelo método descrito em (Amaral, et al. 2007), entretanto podemos simplificar o problema de contagem de estruturas, passando para um problema de quantificação de área e cor de pixels agrupados de forma coerente, bastando selecionar uma região de interesse. A soma de uma "mancha” de interesse, composta pela totalidade dos grãos de amido na imagem, pode ser 
obtida sem a necessidade da contagem do número de grãos, ignorando erros causados por formatos irregulares nos grãos.

\subsection{Ensaios preliminares com imagens}

Os ensaios preliminares com imagens foram feitos utilizando uma imagem padrão de ensaios, das primeiras imagens geradas a partir do ensaio com folhas de goiabeira Psidium guajava L, mostradas nas figuras de (19) a (23), C1 (0h00), C2(7h00), C3(12h00), C4(15h00) e C5(18h00), selecionando a amostra C4 (figura 22), que contém a maior parte dos elementos de estudo e melhor definição de objetos e estruturas indesejadas que necessitam de supressão por filtragem.

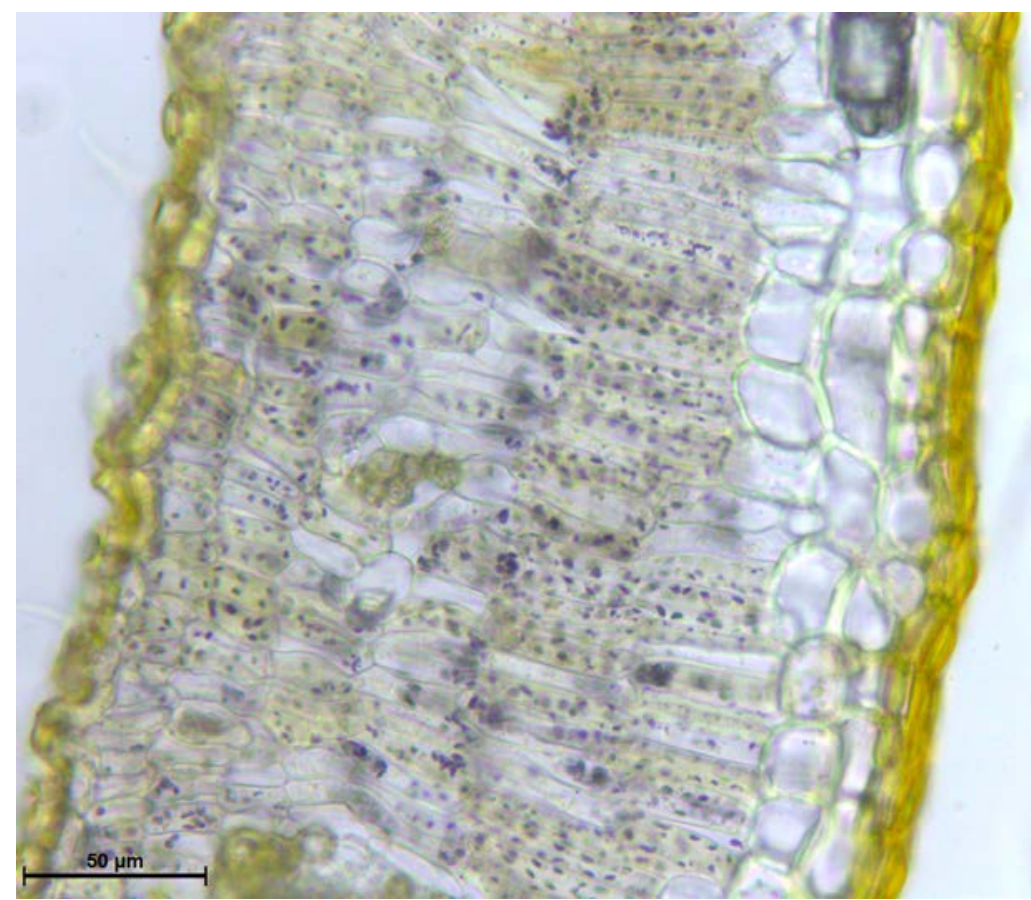

Figura 19 - C1 - corte secção transversal folha de goiabeira Psidium guajava L, amostrada 0h. 


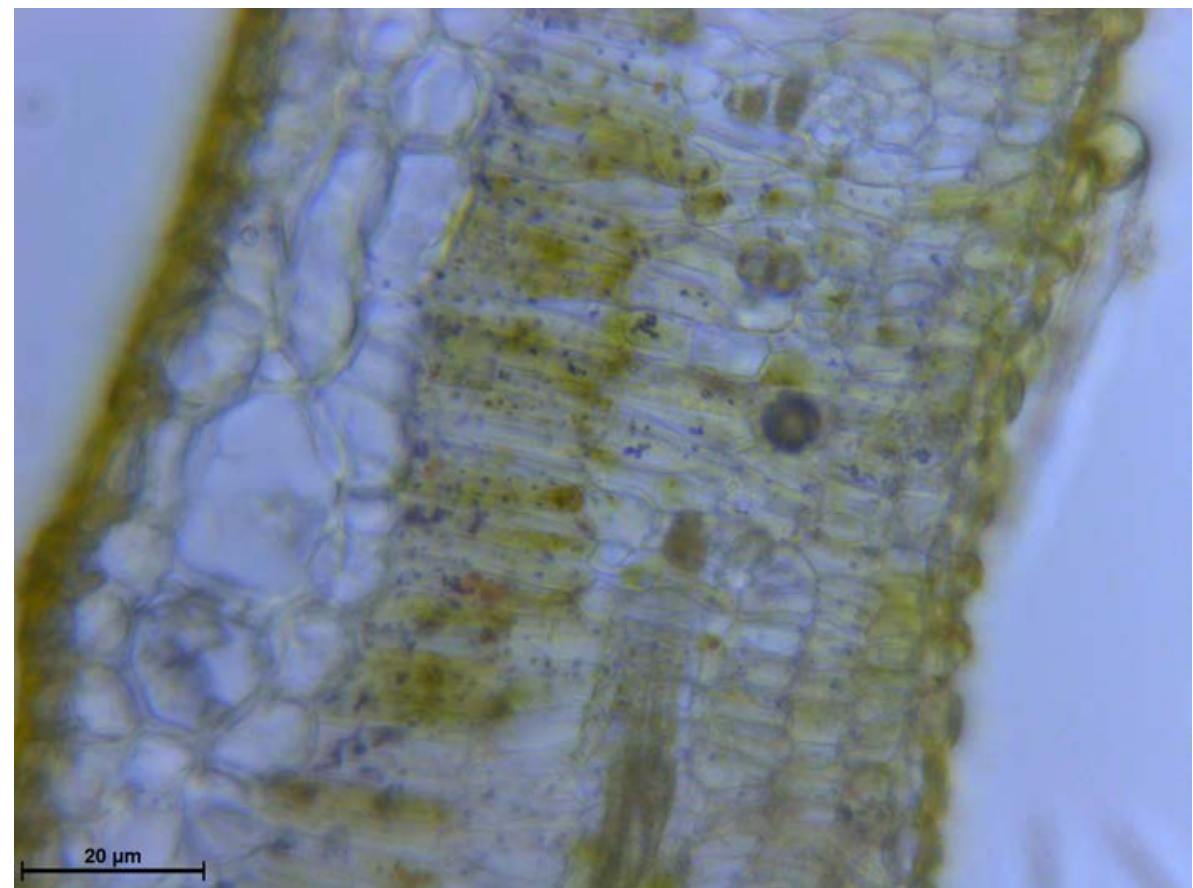

Figura 20 - C2- corte secção transversal folha de goiabeira Psidium guajava L, amostrada 7h.

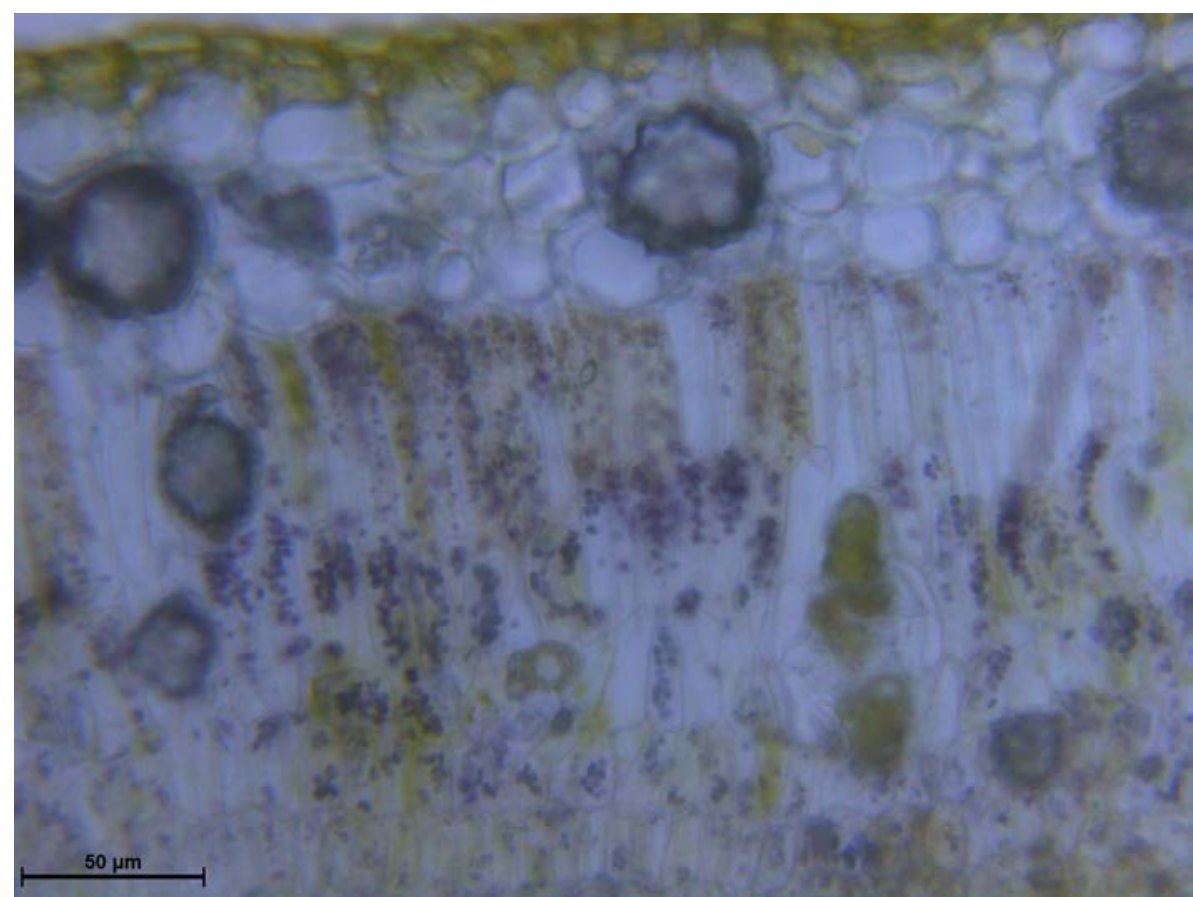

Figura 21 - C3- corte secção transversal folha de goiabeira Psidium guajava L, amostrada 12h. 


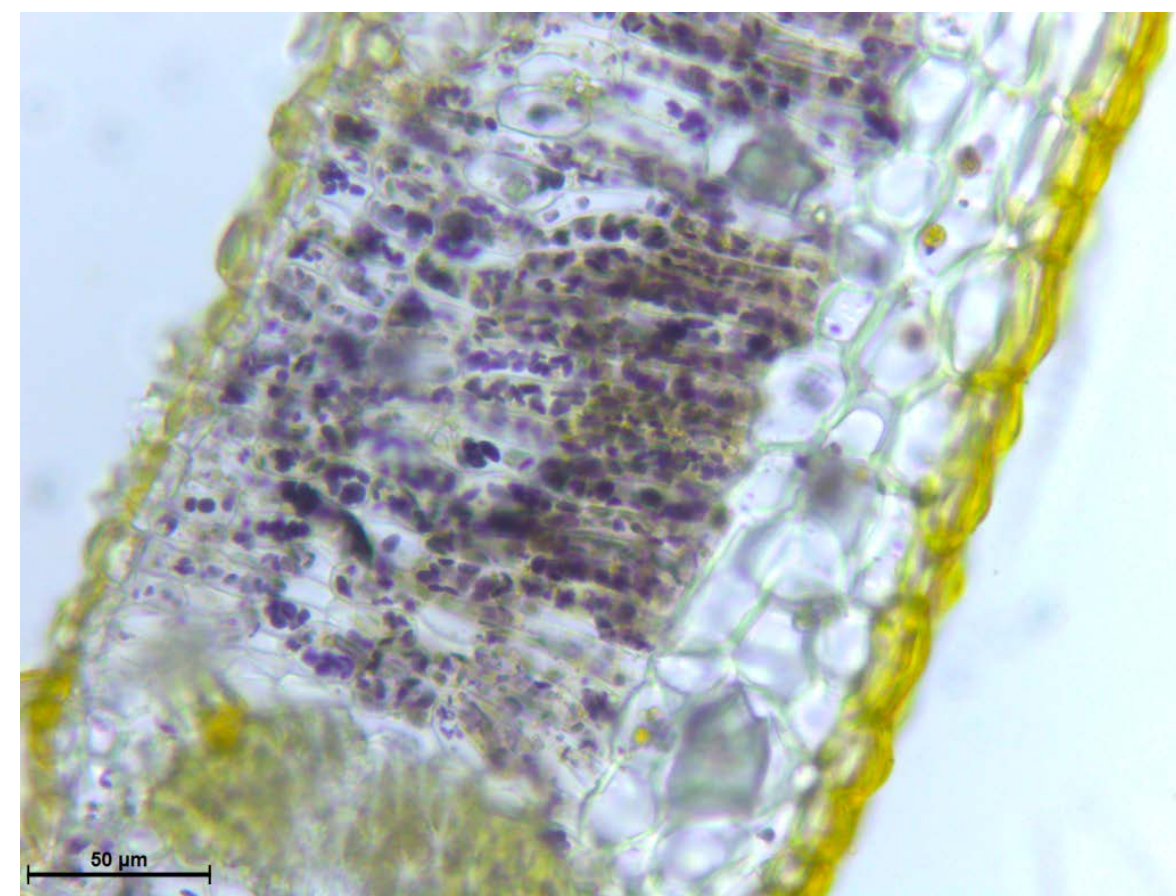

Figura 22 - C4- corte secção transversal folha de goiabeira Psidium guajava L, amostrada 15h.

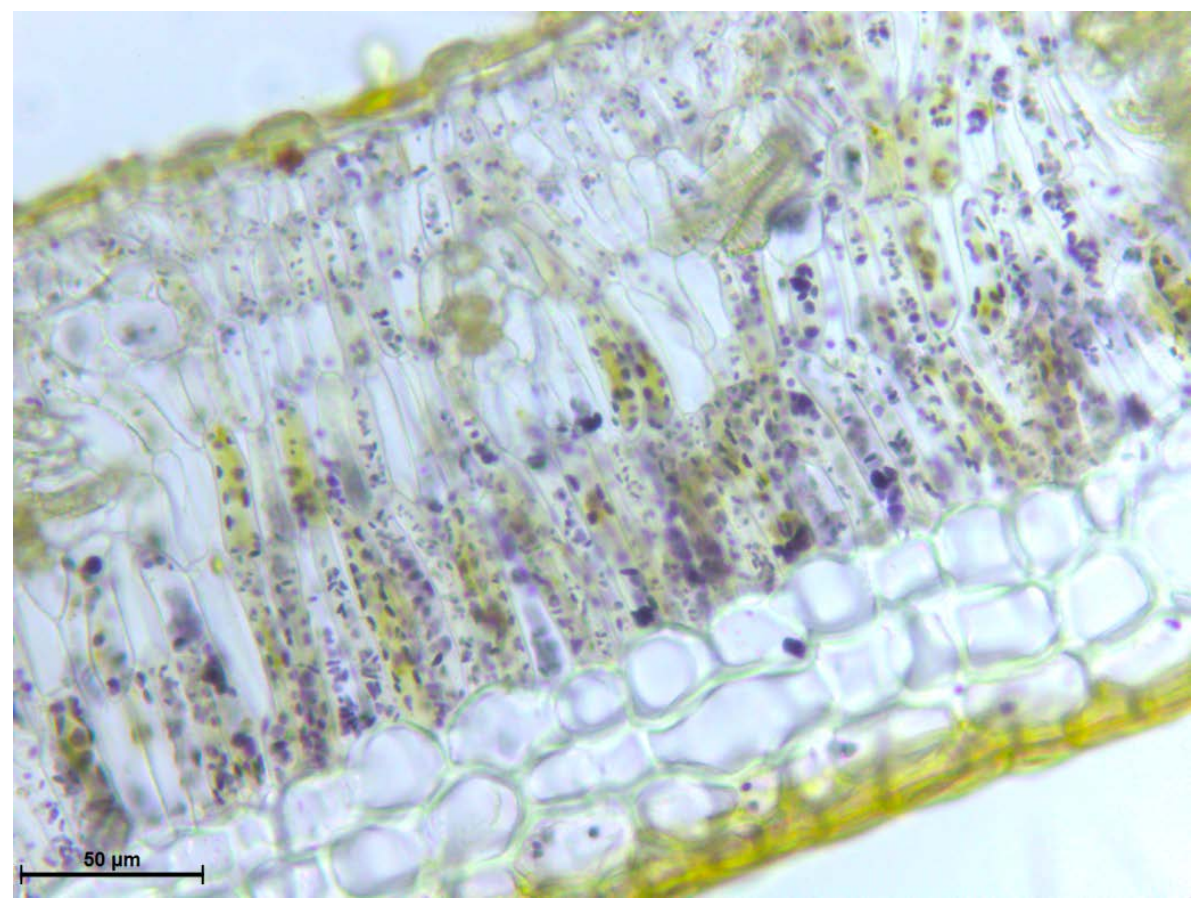

Figura 23 - C5- corte secção transversal folha de goiabeira Psidium guajava L, amostrada 18h.

Seguindo abordagem de Barbedo (2014), foram testados diferentes modelos de mapas de cores para a mesma imagem, com separação por canal de cor, para uma mesma imagem (amostra C4), permitindo inferir qual transformação deve ser utilizada antes do processo de segmentação, possivelmente destacando objetos de interesse mais facilmente, com resultados mostrados nas figuras (24) à (26). Foram testados os mapas de cor RGB, CYM, HSV. 

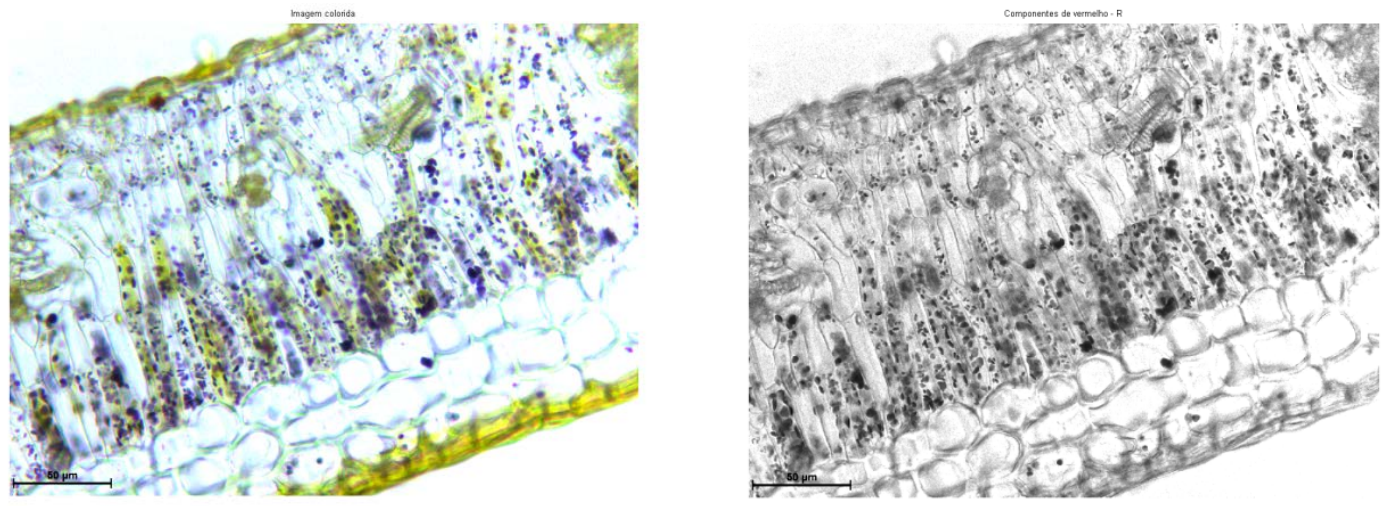

(a)

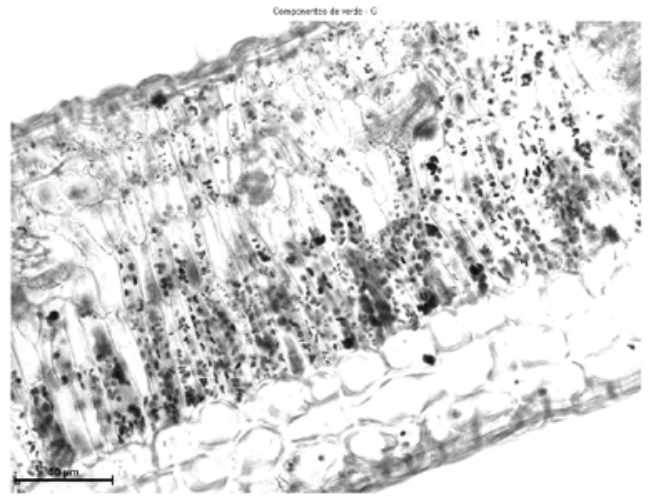

(b)

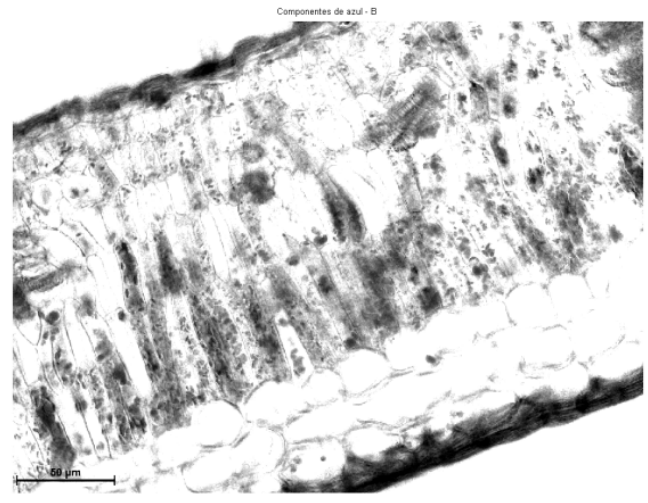

(c)

(d)

Figura 24 (a) Original RGB com ganho em contraste, (b) componente R, (c) componente G, (d) componente B.

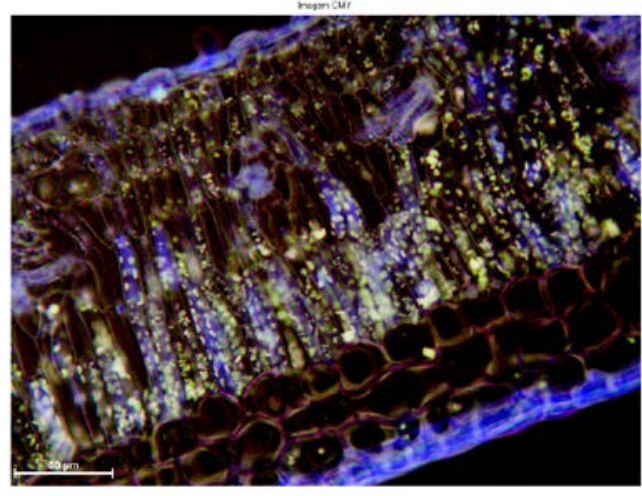

(a)

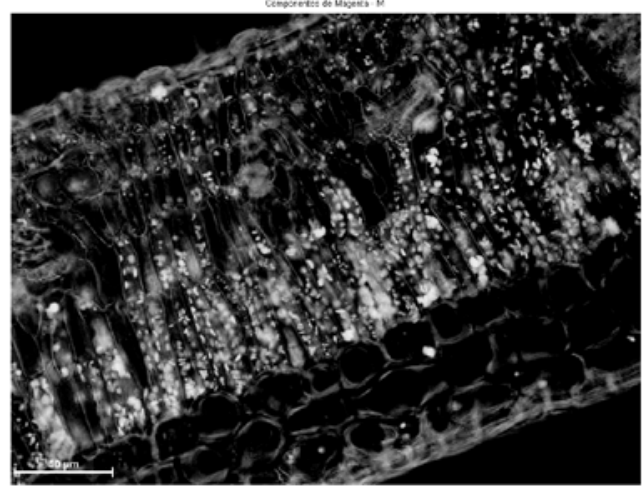

(c)

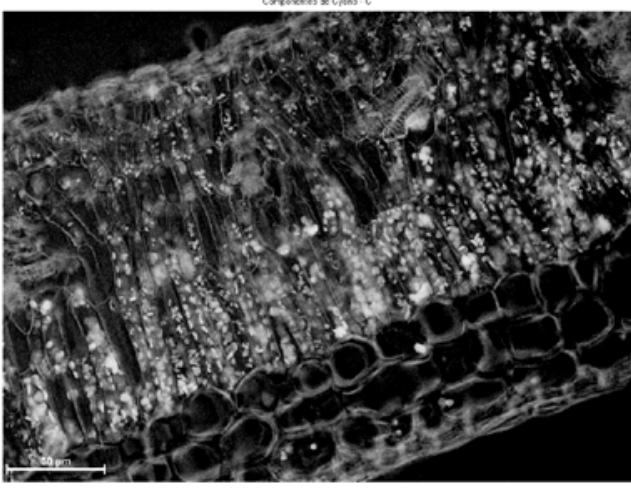

(b)

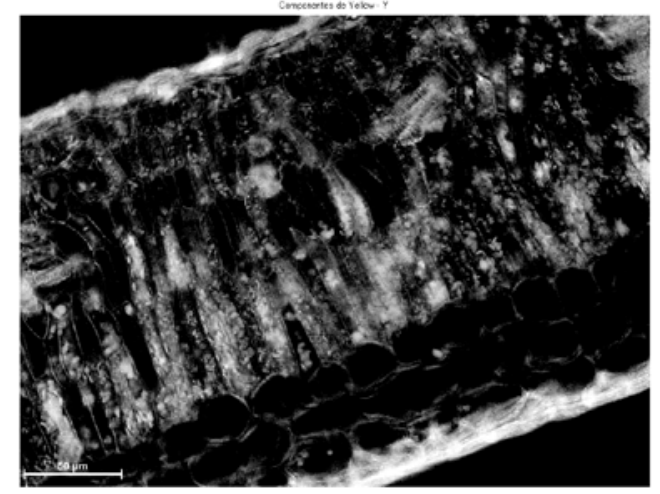

(d)

Figura 25(a) CMY com ganho em contraste, (b) componente C, (c) componente M, (d) componente Y. 


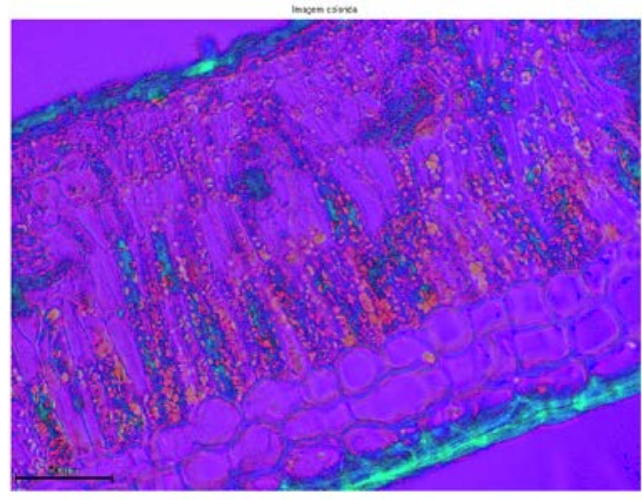

(a)

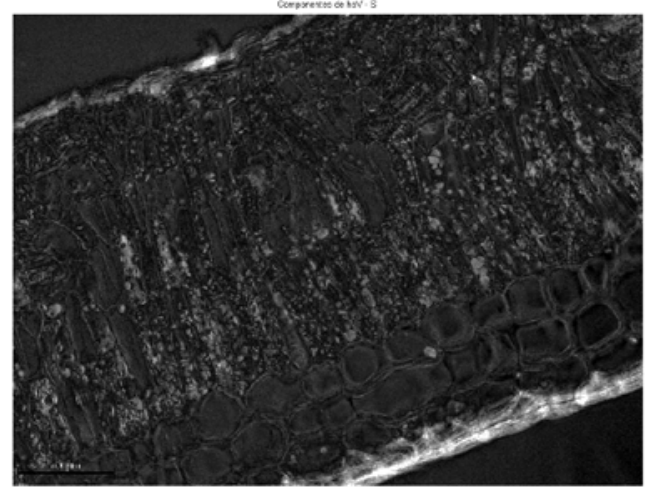

(c)

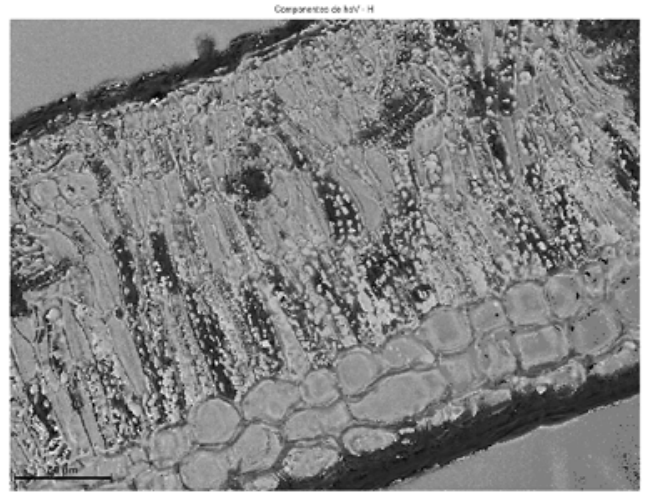

(b)

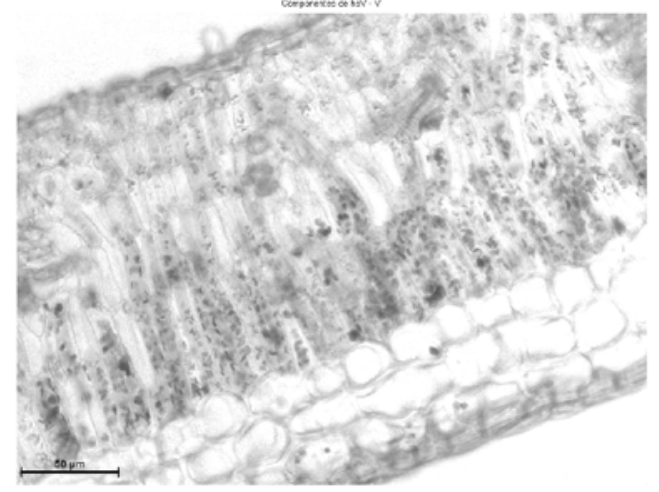

(d)

Figura 26 (a) HSV com ganho em contraste, (b) componente H, (c) componente S, (d) componente V. 


\section{Proposta}

O projeto apresentado segue a base da abordagem inicial, com modificações específicas operacionais, elaborando assim o protocolo aqui proposto, utilizando como estudo de caso as amostras de folha de goiabeira Psidium guajava $L$.

Podemos dividir o processo em duas fases, a primeira de elaboração de curva de calibração, considerando para o tratamento convencional o método de extração e quantificação de amido descrito em (Amaral, et al. 2007) como valor real de quantidade de amido de uma determinada amostra. A segunda fase do processo consiste em introduzir o modelo de processamento de imagem para inferir de forma indireta a quantificação de amido em uma folha.

\subsection{Fase preliminar}

Durante a fase preliminar, é feita a coleta das folhas para os ensaios. As condições no dia da coleta em 14 de setembro de 2016, nascer do sol as 06h03 e pôr do sol as 18h02.

Dados os resultados iniciais satisfatórios, com curva padrão de comportamento das curvas de síntese e degradação da quantidade de amido podendo ser aproximadas por um polinômio de grau 3, foi elaborado o design do experimento coletando amostras uniformes retiradas em intervalos de 3h, com início as 6h00 do dia 14 até as 18 h00 dia 14, duas amostras retiradas por folha de três folhas distintas, em formato de discos de diâmetro $1,7 \mathrm{~cm}$, conforme figura 27 , imediatamente congeladas e armazenadas a $-20^{\circ} \mathrm{C}$, posteriormente tendo seu amido extraído e quantificado conforme protocolo descrito em (Amaral, et al. 2007), para obter um resultado quantitativo sobre o comportamento do acúmulo de amido nas folhas ao longo do dia, elaborando assim a curva inicial de calibração.

Da mesma folha são extraídas duas amostras retangulares com largura padrão de $1 \mathrm{~cm}$ e comprimento padrão maior que 2 diâmetros, limitada ao tamanho da folha amostrada, com a retirada imediatamente fixada em fixador FAA50, posteriormente lavadas em etanol 50\%, duas lavagens 10min, depois passadas para etanol 70\% e assim mantidas até o corte. Os recortes guardam em si distância das bordas e centro da folha, buscando eliminar efeitos de distorção de borda para acúmulo de amido, assim tanto para o recorte retangular quanto para os discos, as amostras padrão devem ser retiradas na parte mais centralizada possível de cada lado da folha, como observado na figura 27. 


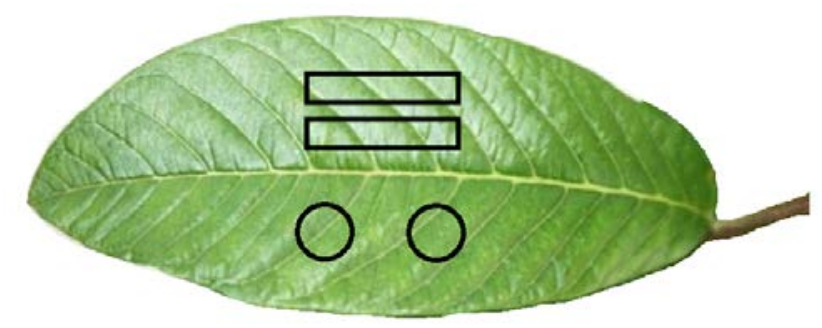

Figura 27 - Amostra de folha padrão, destaque para amostras de discos de 1,7cm de diâmetro e zonas de amostragem retangulares para corte de secção transversal.

Foram feitos cortes utilizando micrótomo de congelamento do laboratório de anatomia vegetal do IB-USP (MICROM KS 34 Thermo Scientific, LEICA SM2000R), com espessura de $10 \mu \mathrm{m}$ (aproximadamente duas camadas de células), limpeza de pigmentos com solução de hipoclorito de sódio 2\%, diluído 50\%, montadas em lâminas com solução de lugol $2 \%$, e observadas com aumento de lente objetiva 20x em microscópio de luz (LEICA DMLB), imagens obtidas com câmera acoplada ao microscópio (LEICA DFC310 FX), mantidas as condições de iluminação e posicionamento das folhas na lâmina como padrão, paralelas ao sentido longitudinal da lâmina.

\subsection{Fase 1}

As amostras foram nomeadas para cada folha, A e A*, B e $\mathrm{B}^{*}$ e $\mathrm{C}$ e $\mathrm{C}^{*}$, e de cada horário de 1 à 5, num total de 6 amostras de discos para extração e quantificação descrito em (Amaral, et al. 2007), em cinco horários distintos, cujos resultados podem ser observados na figura 28, e que seguem o mesmo padrão observado anteriormente na figura 13. 


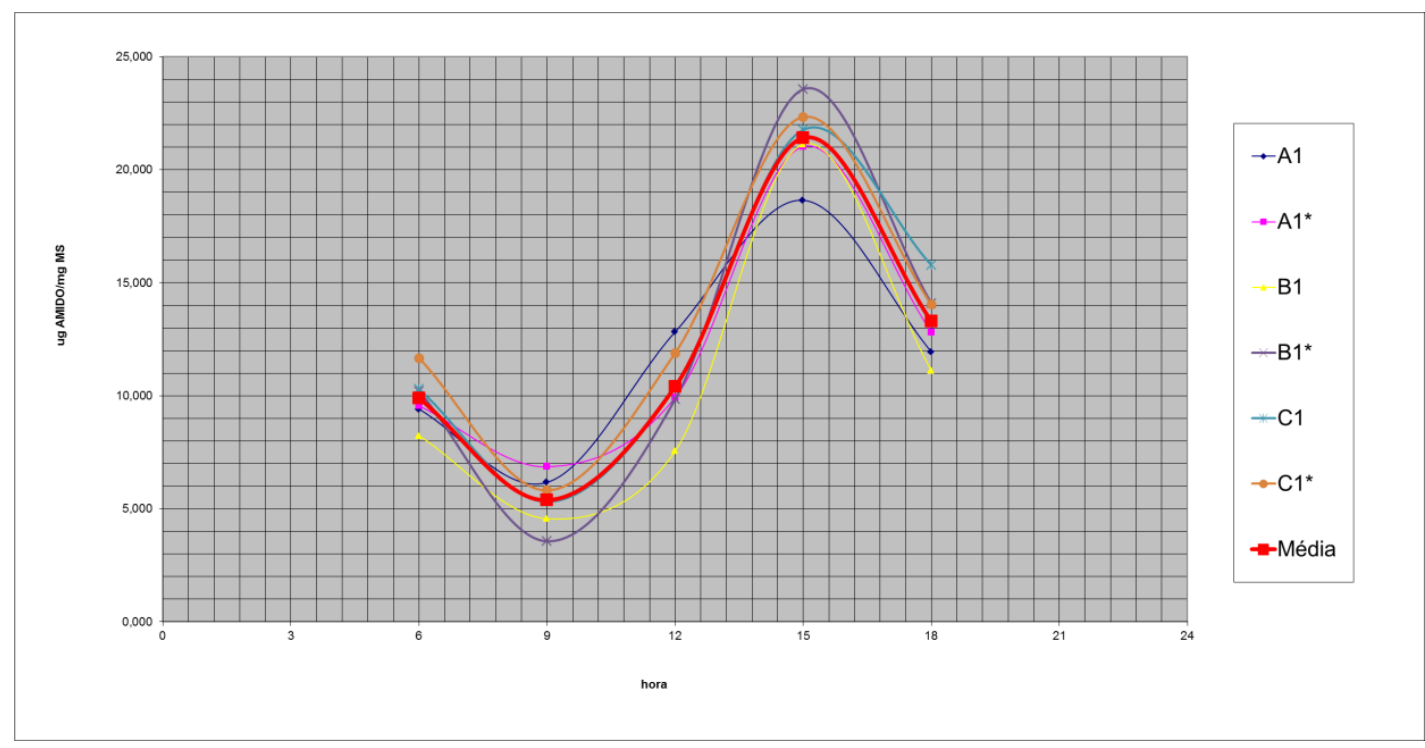

Figura 28 - Quantificação pelo método descrito em (Amaral, et al. 2007) para as amostras A e A*, B e B* e C e C* para os horários de 1 a 5.

\subsection{Fase 2}

Para cada amostra A e A*, B e B* e C e C* para os horários de 1 a 5 , foram retiradas amostras para montagem de lâmina e observação em microscópio de luz, onde para cada horário foram obtidas 6 imagens para cada folha, num total de 18 imagens por horário.

As imagens obtidas passam por processamento de imagem, guarda características básicas dos modelos propostos por (Gonzalez e Woods 1992), após resultados da abordagem inicial, escolhemos o tratamento das imagens e abordagem por cor e área.

O problema foi simplificado, a contagem de estruturas passa a ser um problema de quantificação de área de pixels agrupados de forma coerente em uma imagem binarizada, bastando selecionar uma região de interesse, com soma de "mancha" de interesse, composta pela totalidade dos grãos de amido na imagem, sem a necessidade da contagem do número de grãos, ignorando erros causados por formatos irregulares de outras regiões que possam causar distorção senão àquelas de interesse, restrita à grãos de amido destacados.

O algoritmo foi implementado em Matlab, a sequência de processamento inicia-se com a leitura da imagem de interesse, seguida de separação por canal de cor RGB. Cada canal RGB representa uma imagem em escala de cinza, em que os grãos de amido ficam mais destacados facilitando posterior binarização da imagem ao selecionar o canal correspondente ao verde (G). Ao canal selecionado, aplica-se a binarização dado um limiar correspondente, buscando obter uma obtendo uma imagem 2-D lógica binária com sequência numérica real 
não dispersa, em que pixels não-zero pertencem à um objeto e pixels 0 constituem um pano de fundo “background”, através da função pré-definida “im2bw”.

$$
\mathrm{BW}=\mathrm{im} 2 \mathrm{bw}(\mathrm{I}, \text { level })
$$

Converte a imagem em escala de cinza I em uma imagem binária. A imagem de saída BW substitui todos os pixels da imagem original com luminância maior do que um determinado valor limiar por 1 (branco) e substitui todos os outros pixels pelo valor 0 (preto). O valor especificado de limiar "level” varia entre [0,1], representando qualquer valor de uma escala de cinza, onde o valor central entre preto e branco na escala é igual à 0,5.

Utiliza-se a função pré-definida “bwboundaries” que implementa o algoritmo de traçado de bordas de Moore-Neighbor modificado pelo critério de parada de Jacobs’s, baseado na função de identificação de bordas apresentado por (R. C. Gonzalez 2004), identificando assim todos os objetos contidos na imagem binária. Identificam-se as bordas dos objetos e traça-se um contorno em verde, através do algoritmo a seguir:

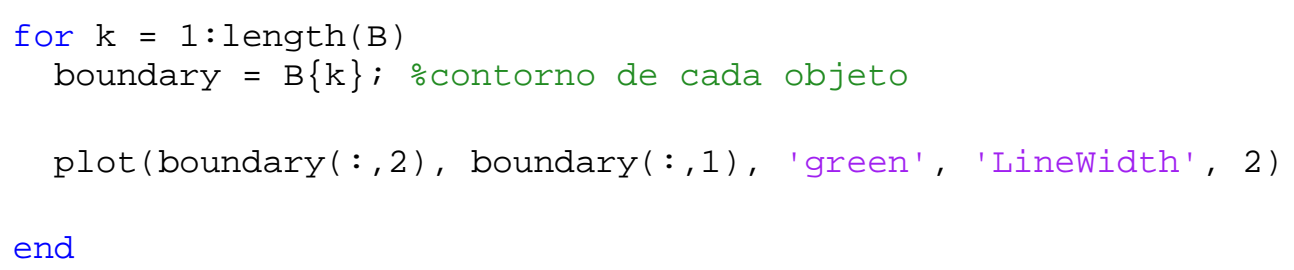

O último passo é aplicar a função pré-definida em matlab “regionprops” que explora as propriedades de objetos em imagens binarizadas, exploramos a propriedade de área dos objetos, como no trecho do algoritmo a seguir:

stats = regionprops $(\mathrm{L}$, 'Area');

Cria uma matriz de vetores contendo a área de cada uma das regiões objeto encontradas na imagem binária e às rotula e numera de acordo com o número de objetos encontrado na imagem. 
Uma região contínua de pixels pode ser chamada de Objeto, componentes conectados ou bolhas. A matriz rotulada contendo regiões contíguas pode se parecer com a seguinte matriz:

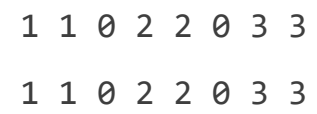

Elementos de L iguais a 1 pertencem à primeira região contígua ou de componentes conectados, elementos de L iguais a 2 pertencem à segunda, e assim por diante.

Regiões discontíguas são regiões em que podem conter múltiplos componentes conectados, a matriz rotulada contendo regiões discontíguas pode se parecer com a seguinte matriz:

Elementos de L iguais à 1 pertencem à primeira região, que é descontígua e contém dois componentes desconectados. Elementos de L iguas à 2 pertencem à segunda região, que é um único componente conectado.

O algoritmo que realiza a identificação das áreas e armazenagem da informação na matriz AA é o seguinte:

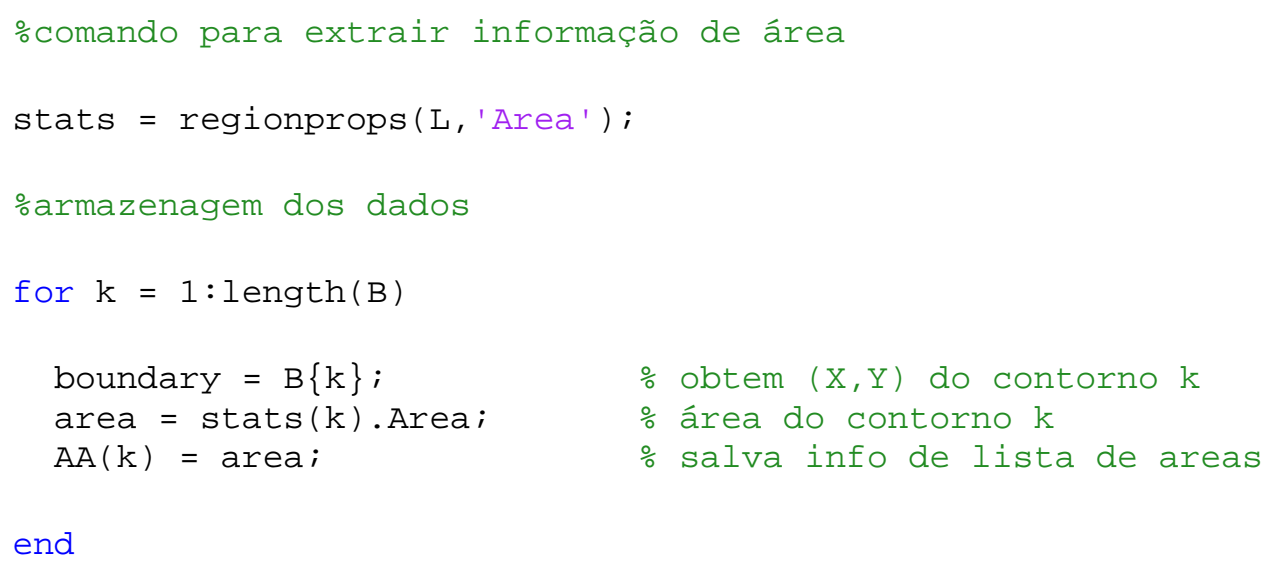


O algoritmo é aplicado a todas as imagens, gerando uma matriz de objetos área em pixels para cada imagem. São observadas e descartadas as regiões com valores de área não correspondentes a objetos destacados correspondentes à grãos de amido, obtendo no final um valor de área de pixels de objetos grãos de amido para cada imagem.

Para cada horário, a sequência de procedimentos pode ser observada na figura 29.

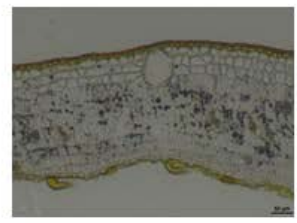

A

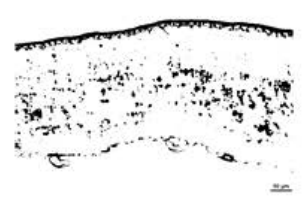

C

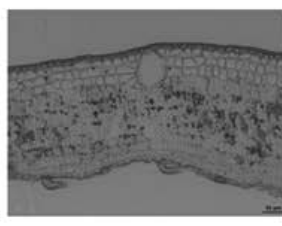

B

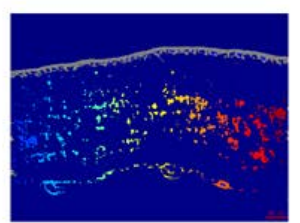

D

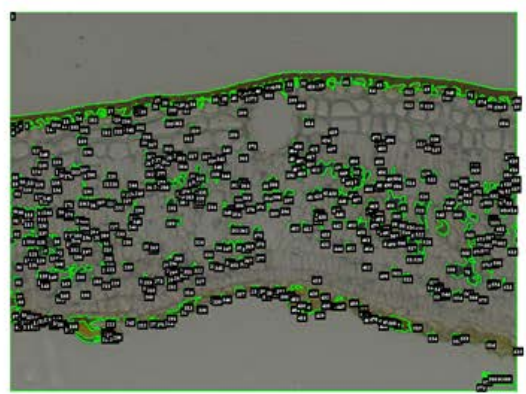

E

Figura 29 - Etapas do processamento de imagem. A - imagem original; B- Imagem em escala de cinza destacada do canal verde (G); C- Imagem binarizada; D - Imagem com regiões destacadas por espalhamento de cor para facilitar interpretação de regiões de interesse; E- Imagem com objetos de interesse destacados e etiquetados na imagem original.

Para cada horário, de 1 a 5, pode-se observar o processo completo, na sequência de figuras de Figura 30 à Figura 54, em que todo o processamento de imagem é destacado em sequência como na figura 29, iniciando por imagem original, seguida da imagem em escala de cinza destacada do canal verde (G), seguida da imagem binarizada, seguida da imagem com regiões destacadas por espalhamento de cor para facilitar interpretação de regiões de interesse finalizada pela imagem com objetos de interesse destacados e etiquetados na imagem original. 


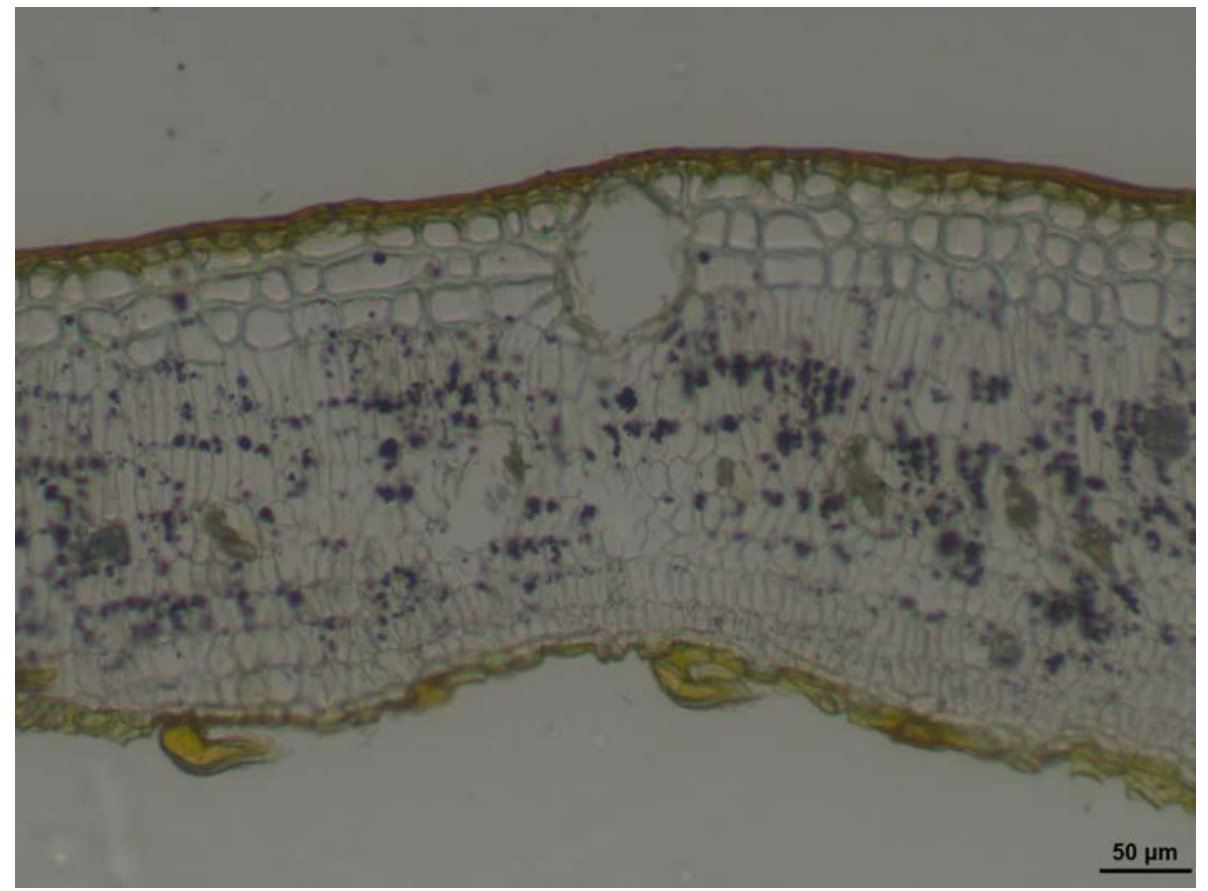

Figura 30 - E1 - imagem original $-6 \mathrm{~h}$.

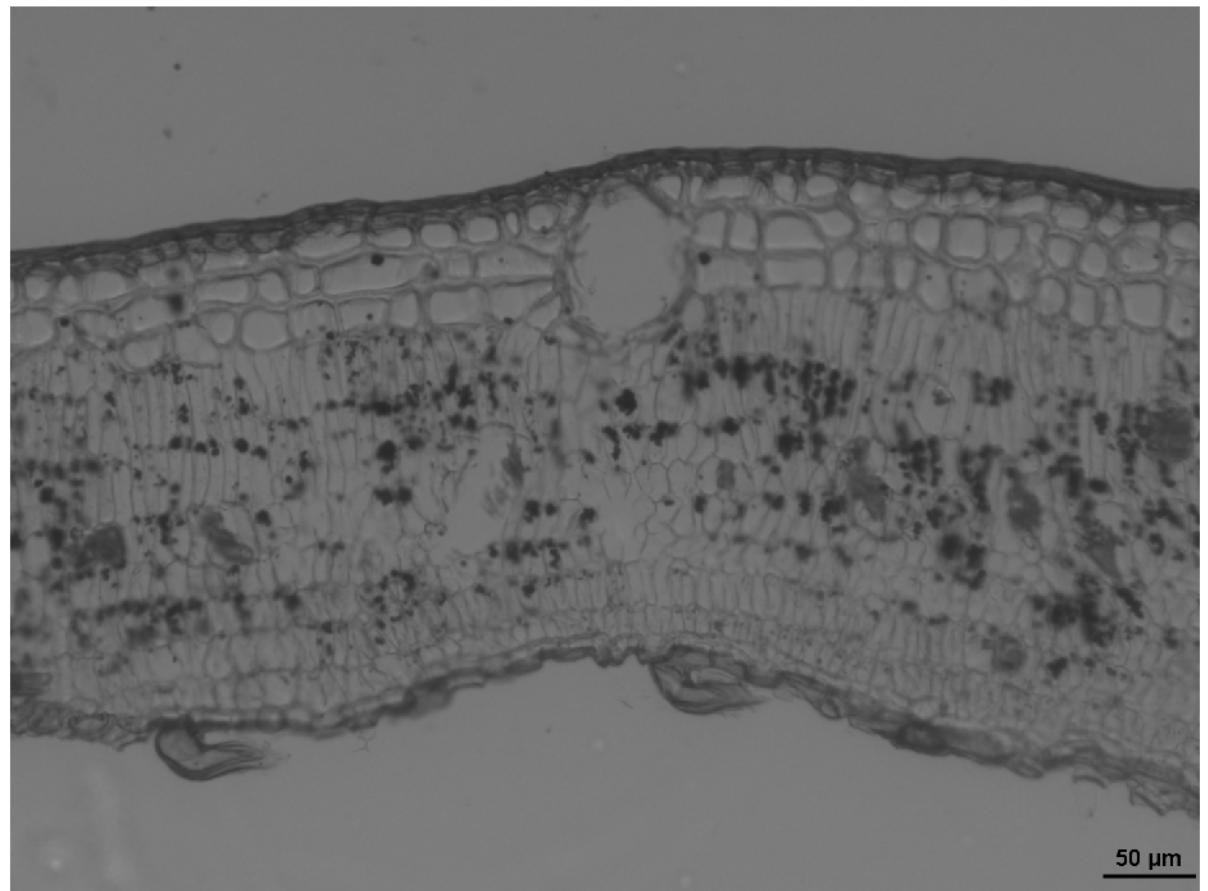

Figura 31 - E1 - Imagem em escala de cinza destacada do canal verde (G). 


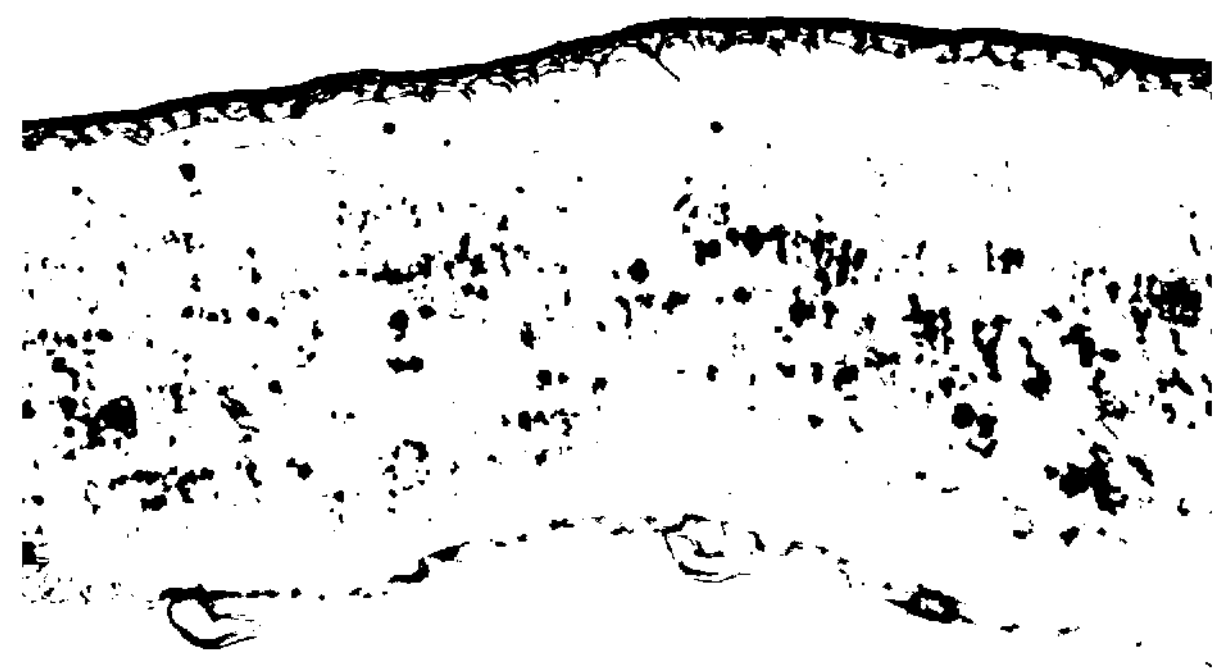

$50 \mu \mathrm{m}$

Figura 32 - E1 - Imagem binarizada.

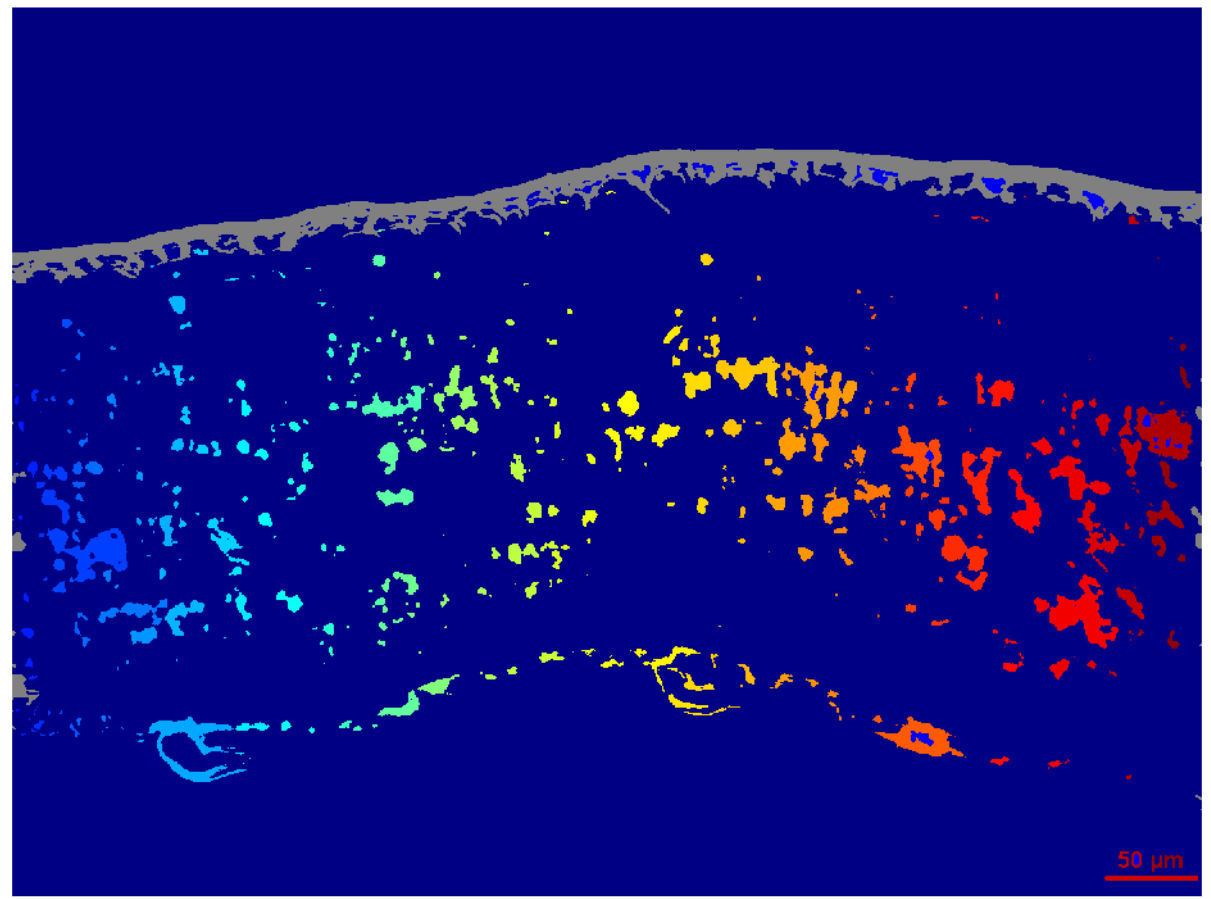

Figura 33 - E1 - Imagem com regiões destacadas por espalhamento de cor para facilitar interpretação de regiões de interesse. 


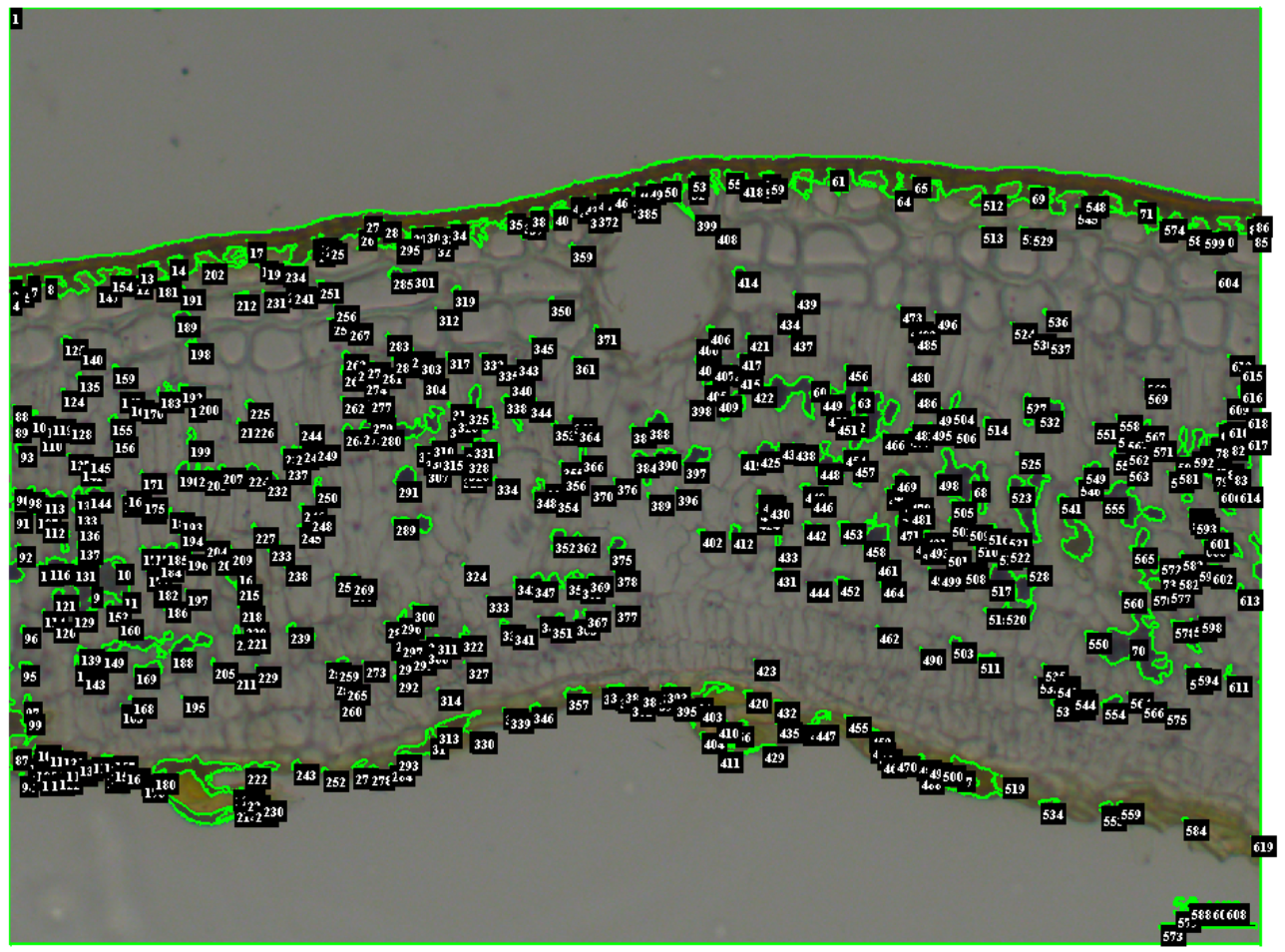

Figura 34 - E1 - Imagem com objetos de interesse destacados e etiquetados na imagem original.

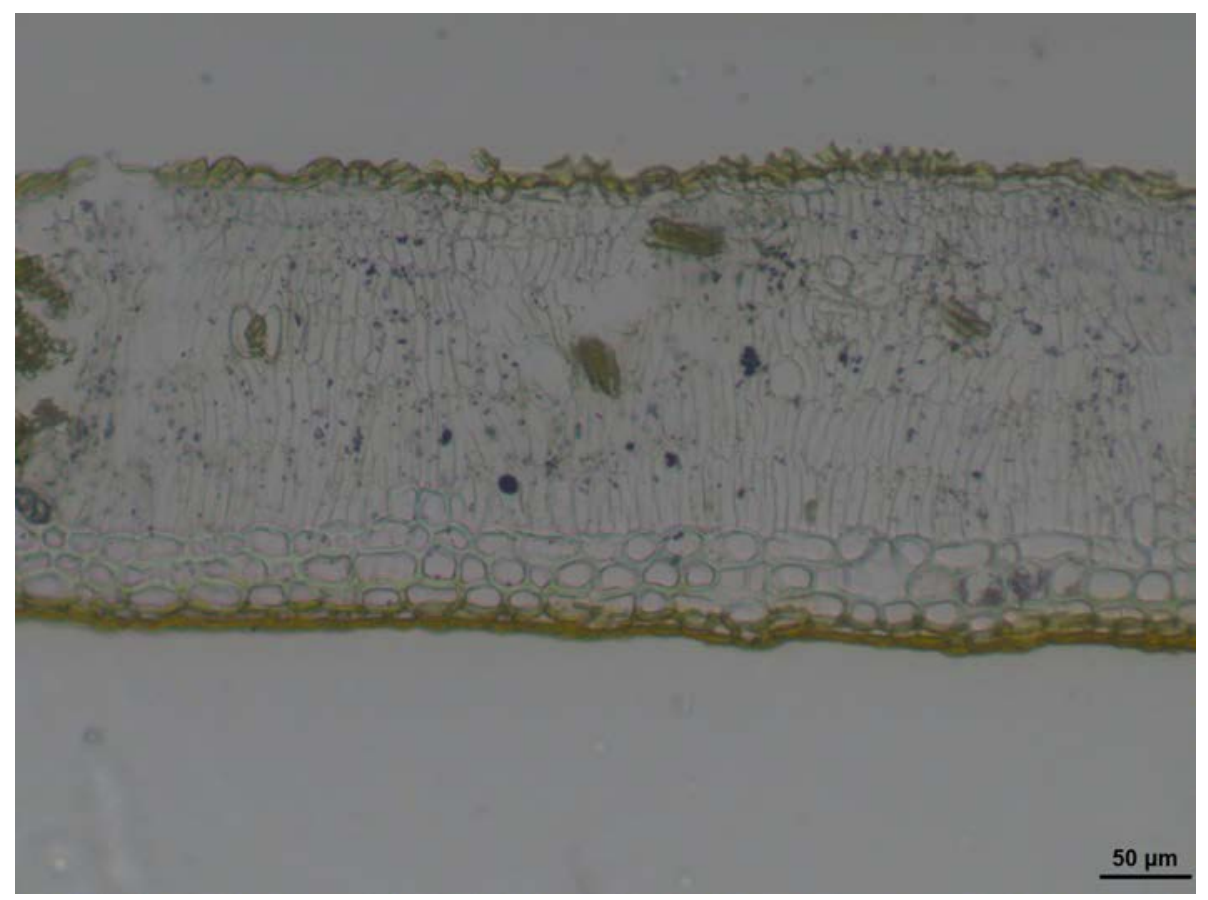

Figura 35 - E2 - imagem original - 9h. 


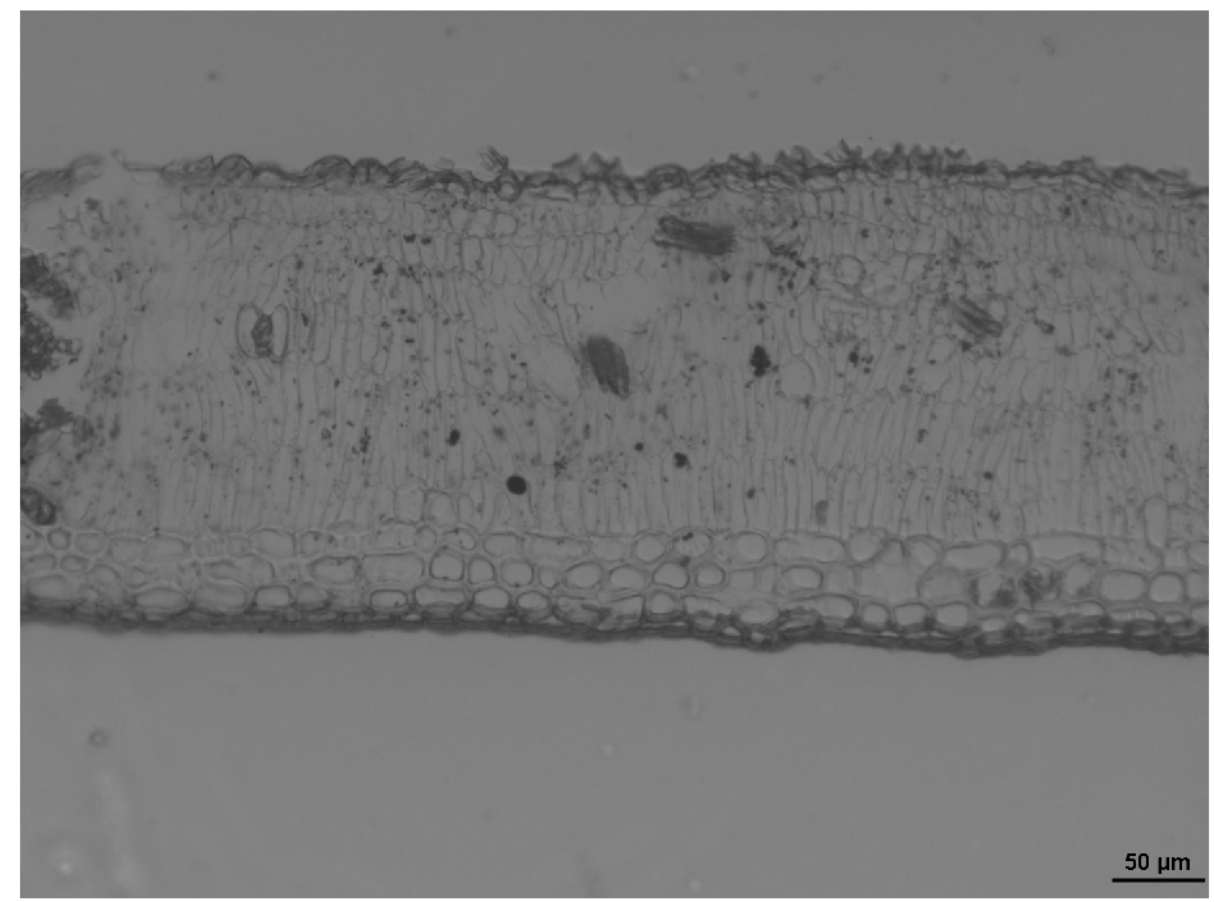

Figura 36 - E2 - Imagem em escala de cinza destacada do canal verde (G).

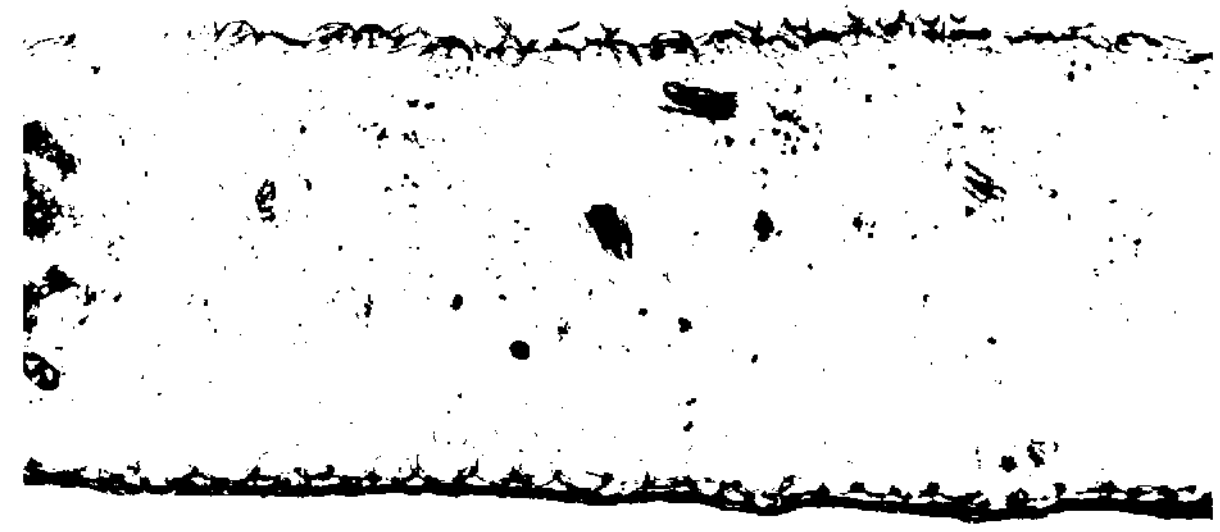

Figura 37 - E2 - Imagem binarizada. 


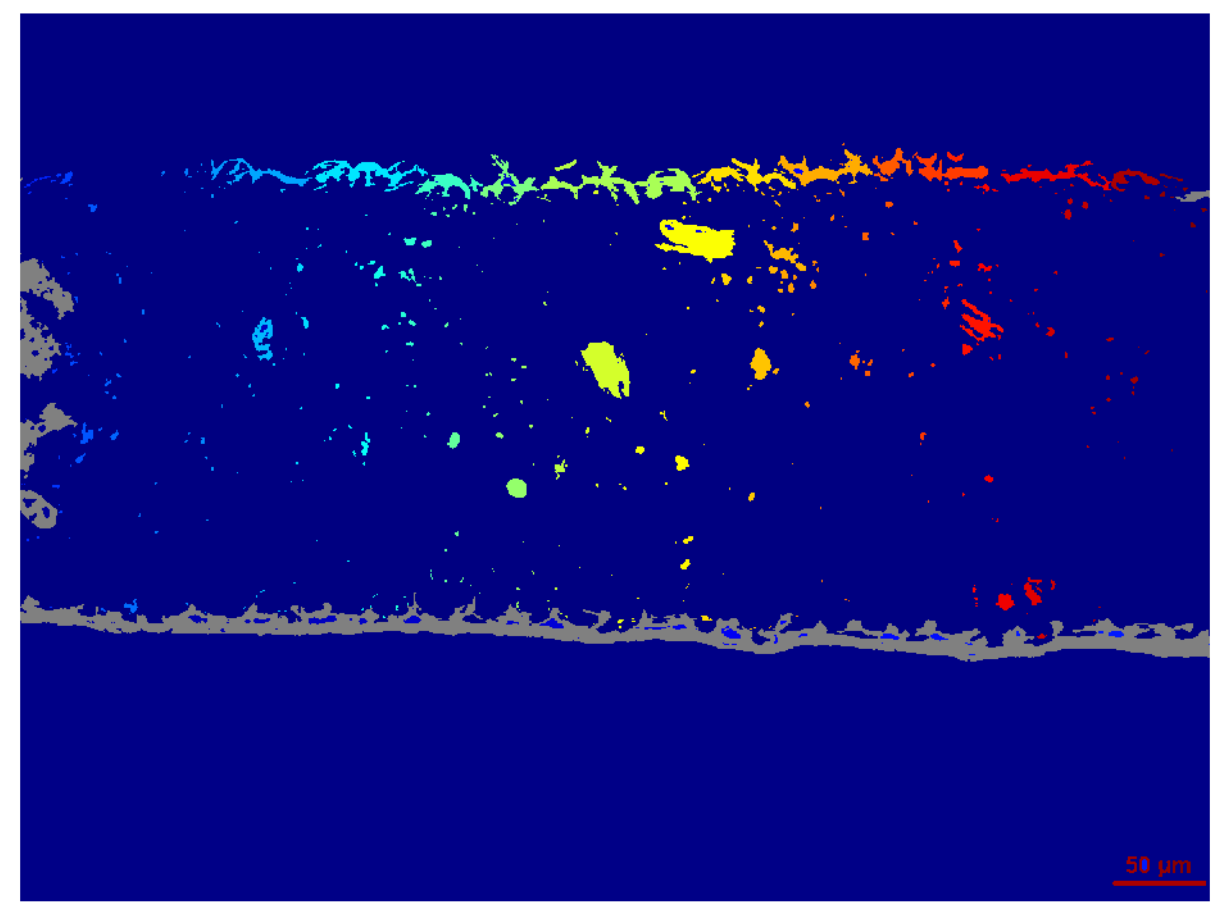

Figura 38 - E2 - Imagem com regiões destacadas por espalhamento de cor para facilitar interpretação de regiões de interesse.

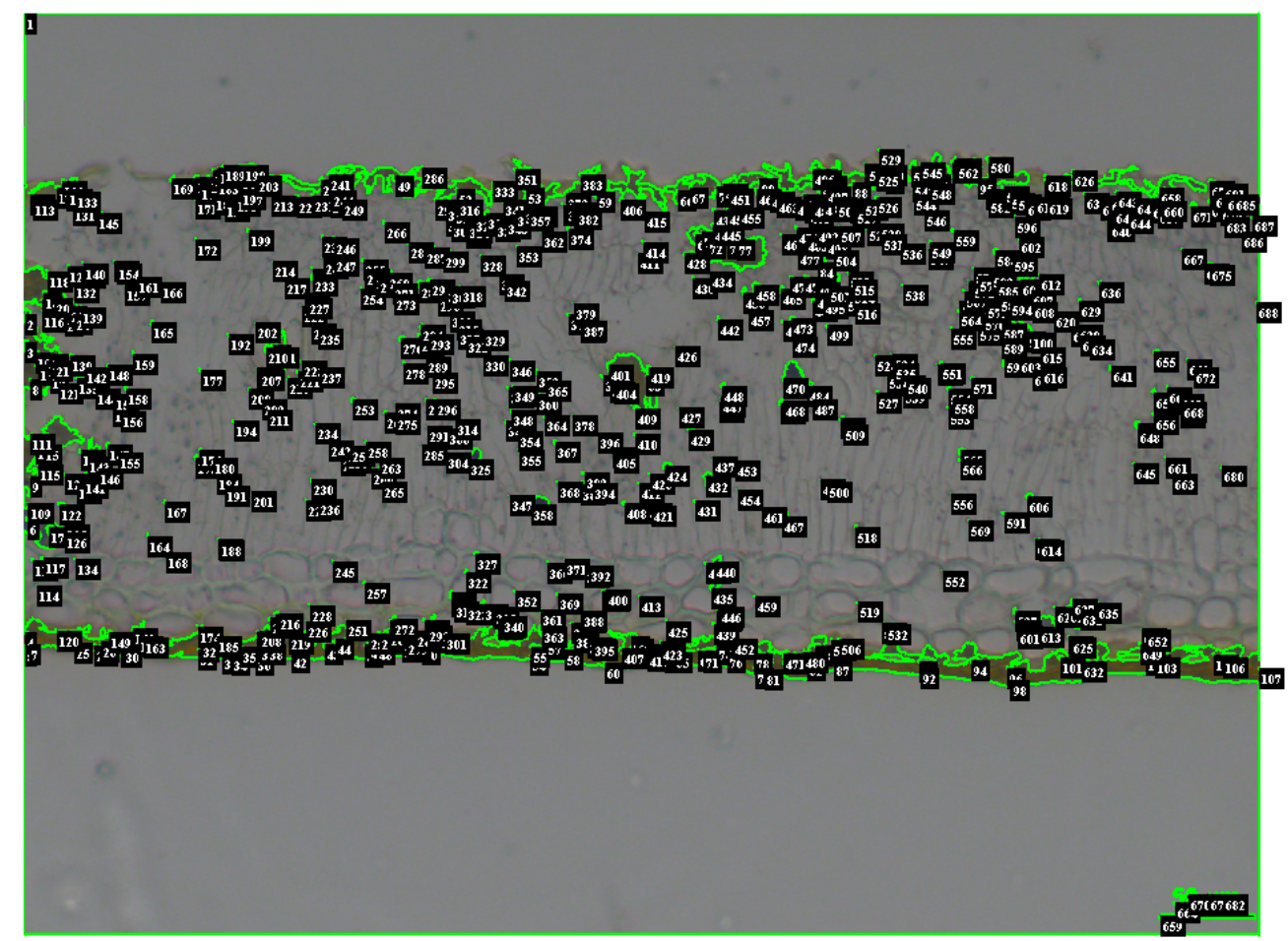

Figura 39 - E2 - Imagem com objetos de interesse destacados e etiquetados na imagem original. 


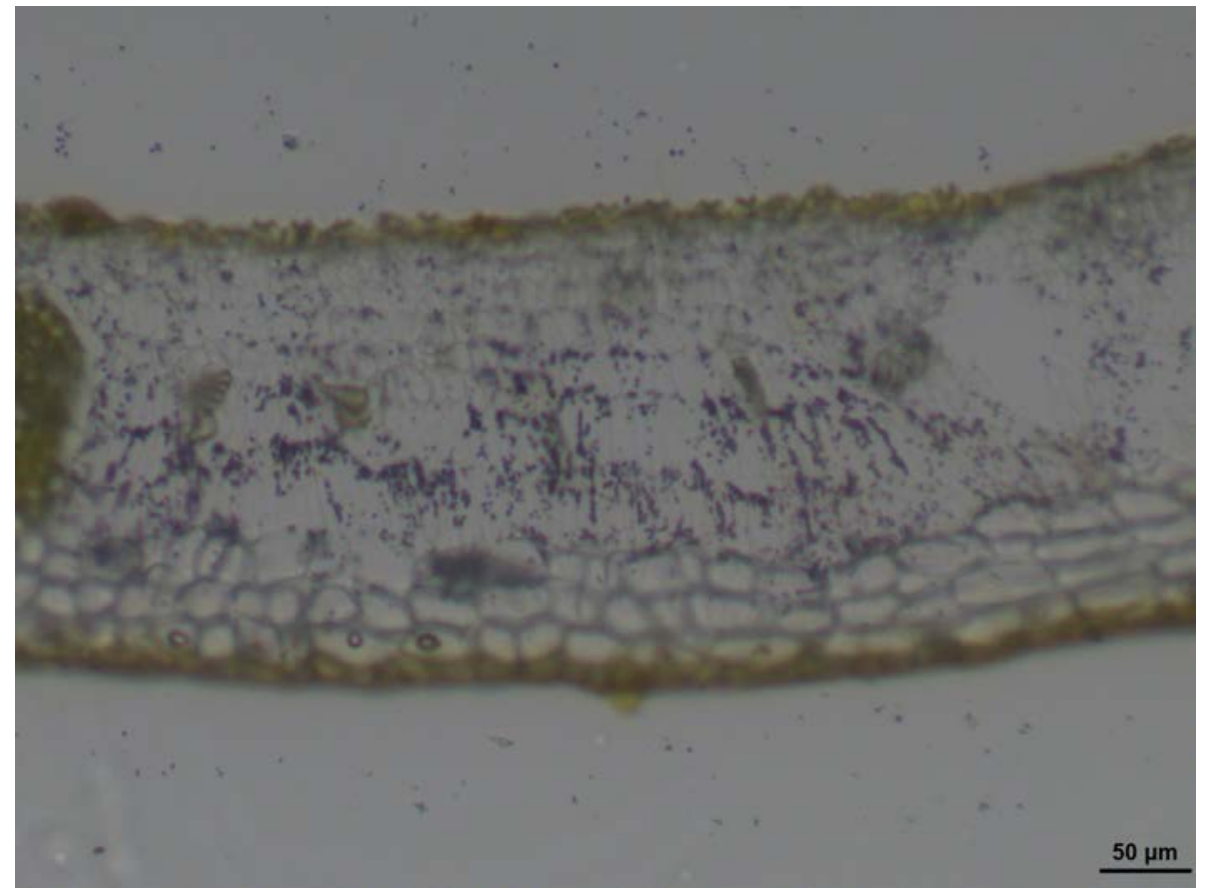

Figura 40 - E3 - imagem original - 12h.

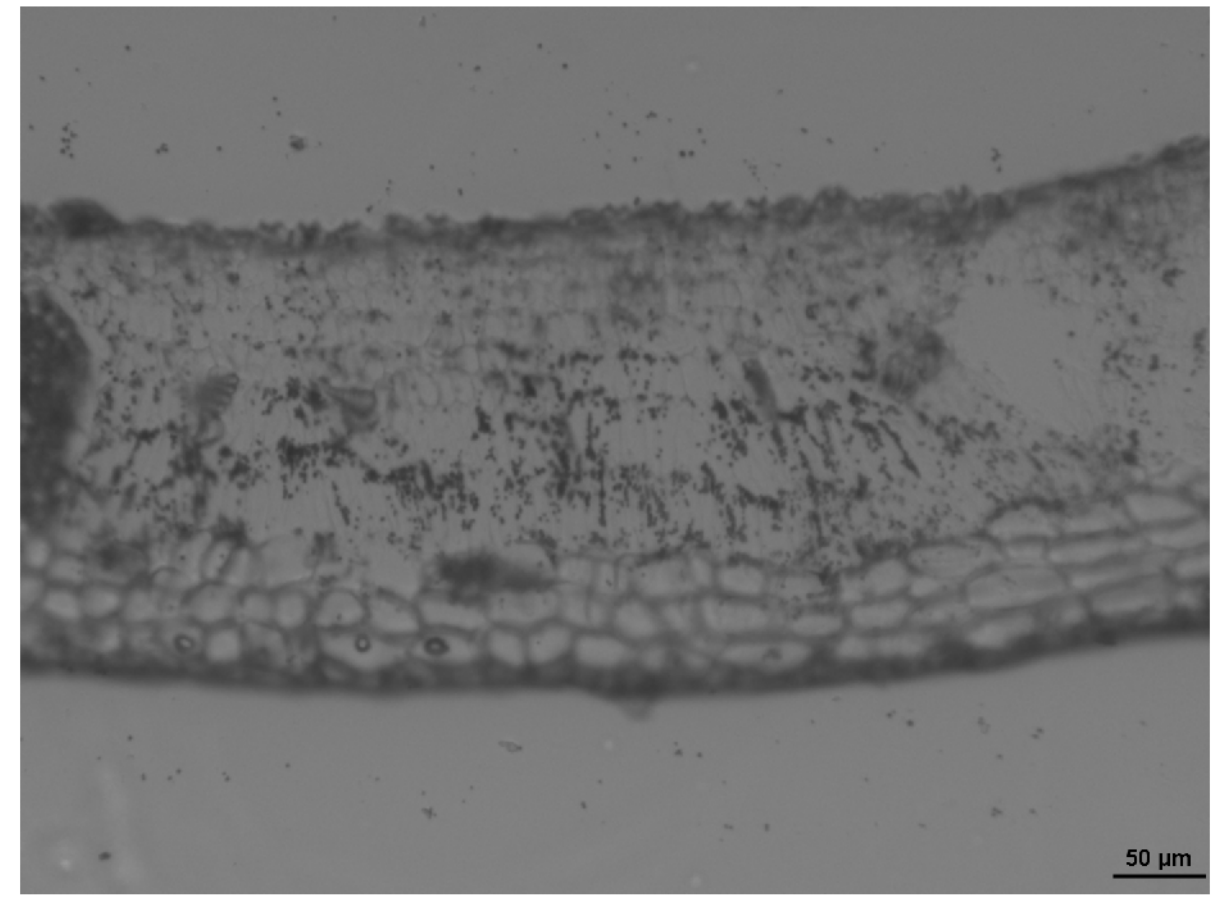

Figura 41 - E3 - Imagem em escala de cinza destacada do canal verde (G). 


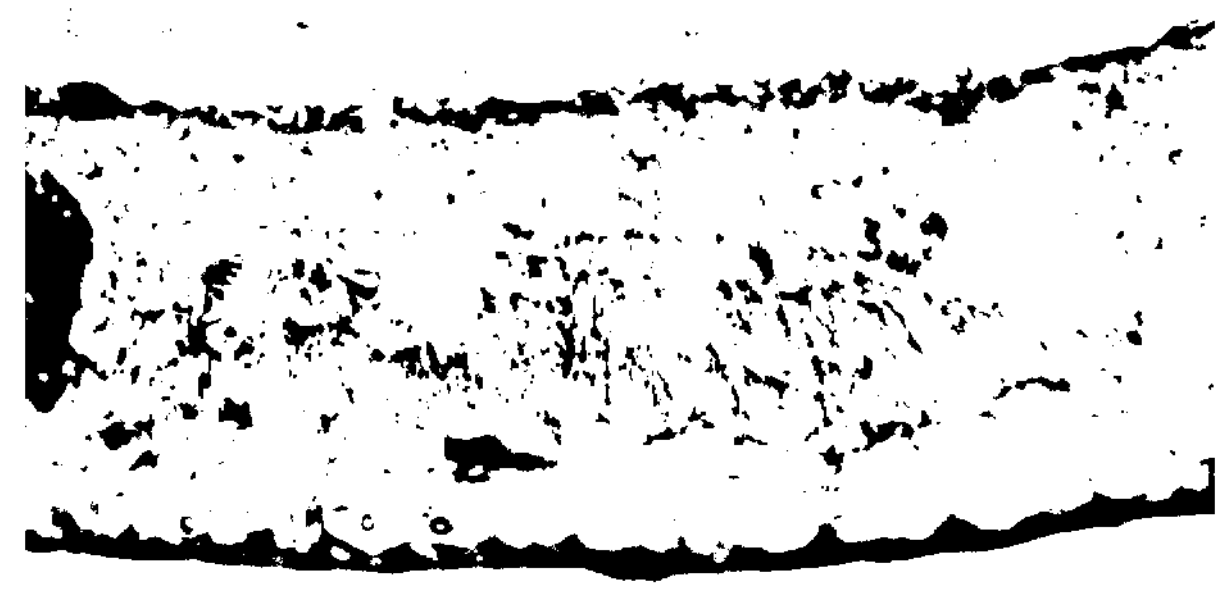

$50 \mu \mathrm{m}$

Figura 42 - E3 - Imagem binarizada.

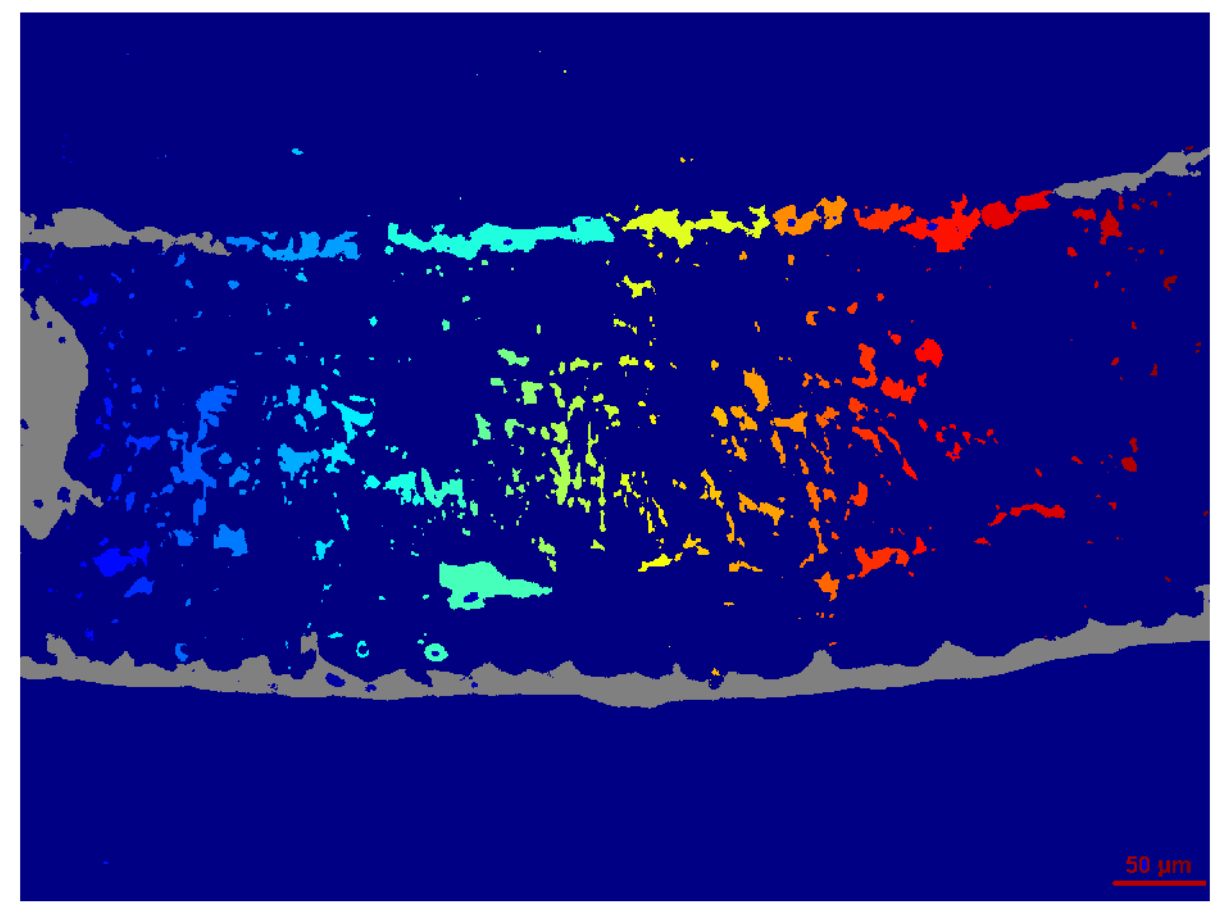

Figura 43 - E3 - Imagem com regiões destacadas por espalhamento de cor para facilitar interpretação de regiões de interesse. 


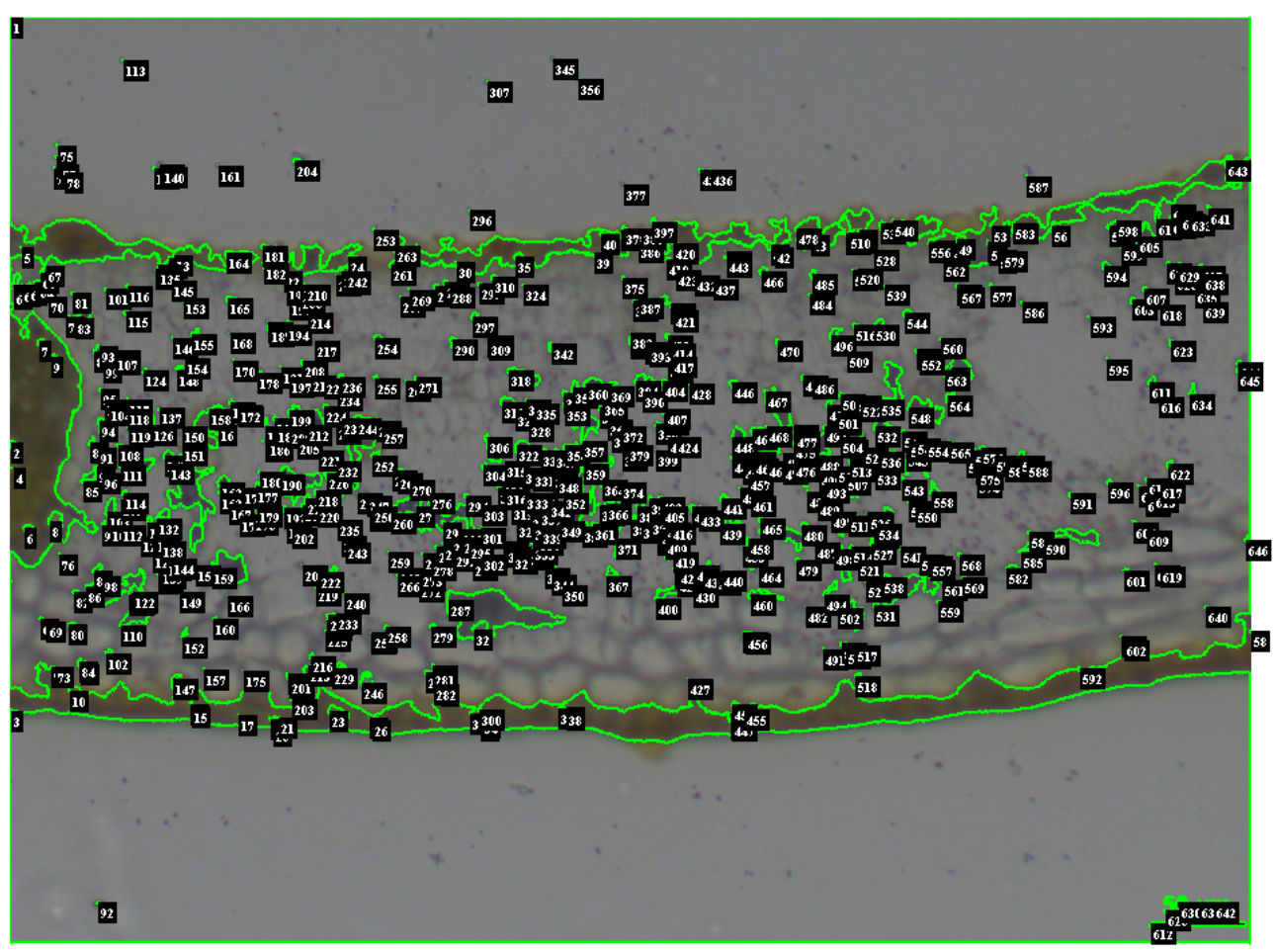

Figura 44 - E3 - Imagem com objetos de interesse destacados e etiquetados na imagem original.

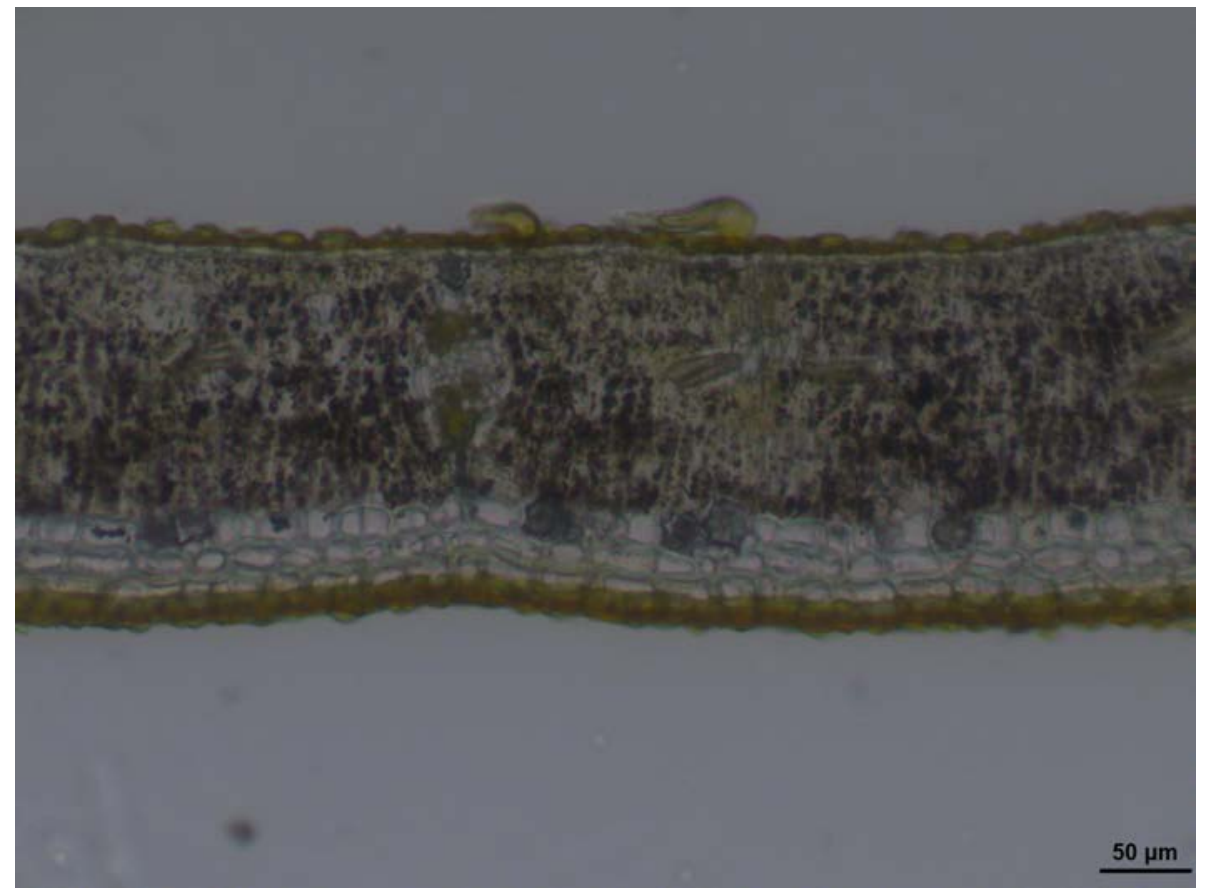

Figura 45 - E4 - imagem original - 15h. 


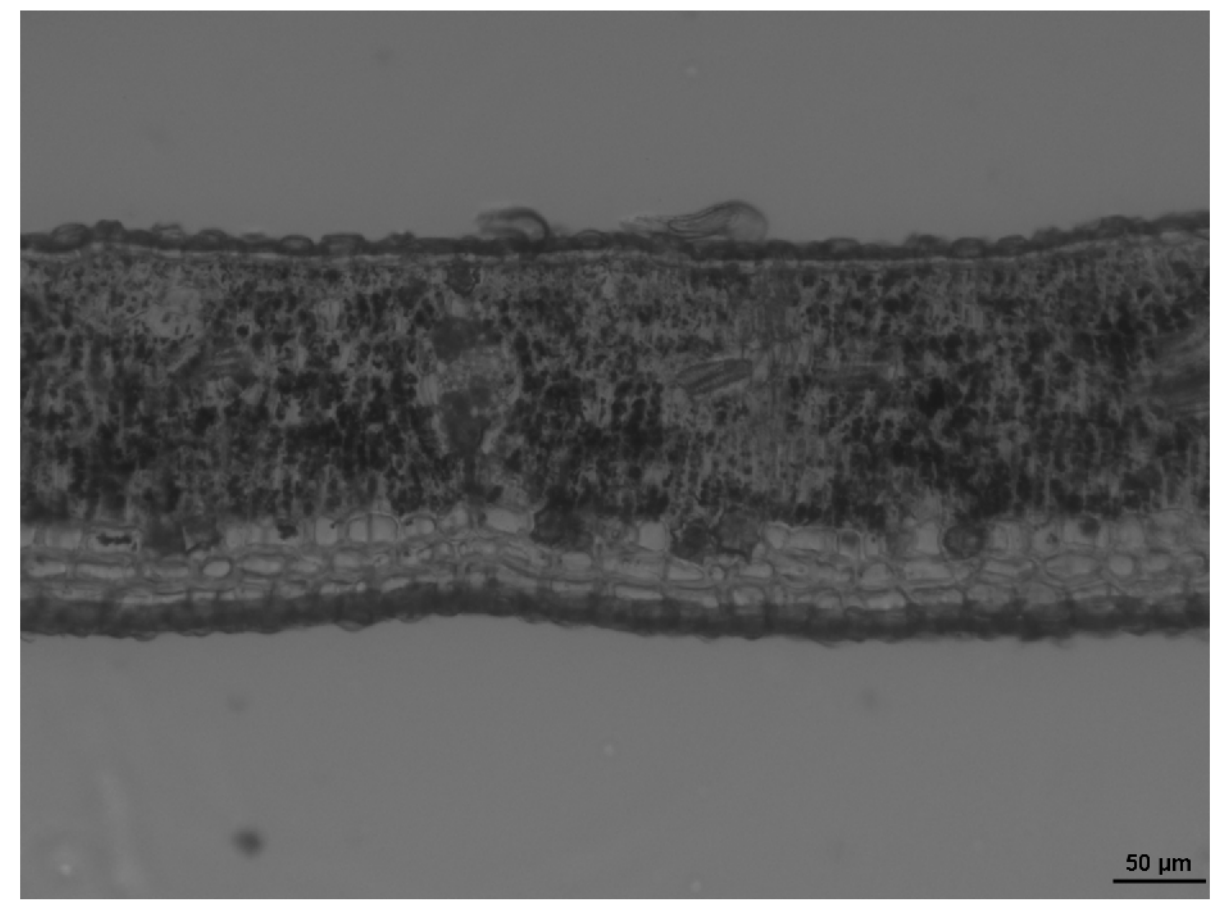

Figura 46 - E4 - Imagem em escala de cinza destacada do canal verde (G).

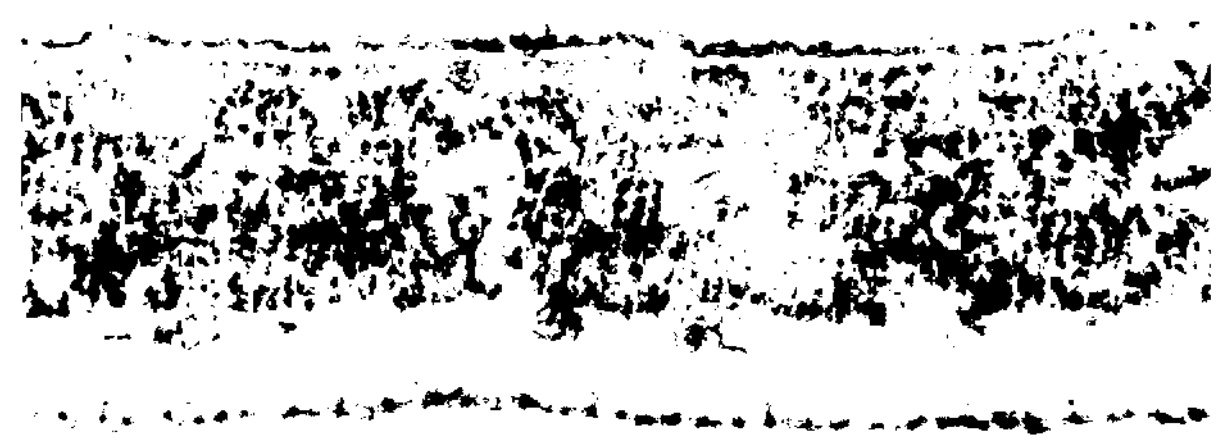




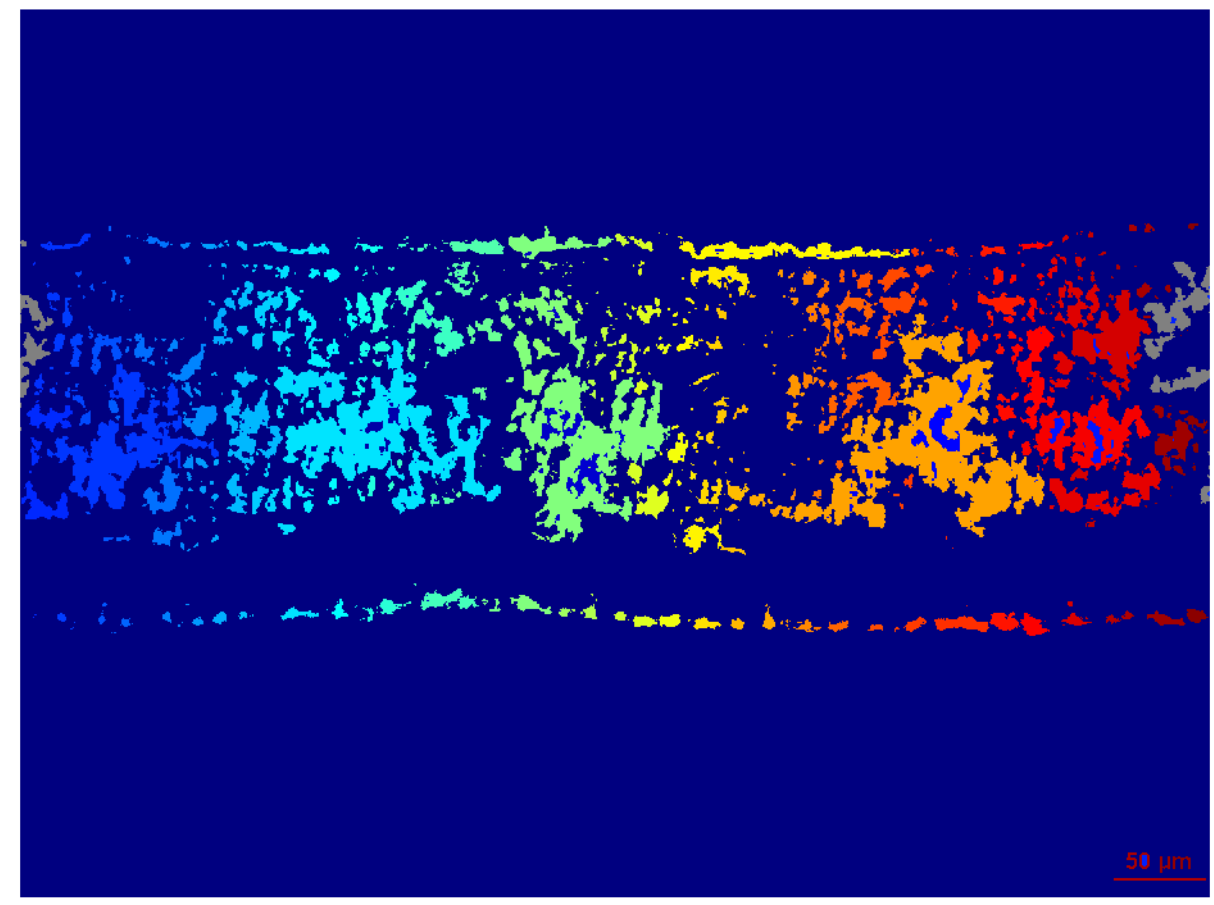

Figura 48 - E4 - Imagem com regiões destacadas por espalhamento de cor para facilitar interpretação de regiões de interesse.

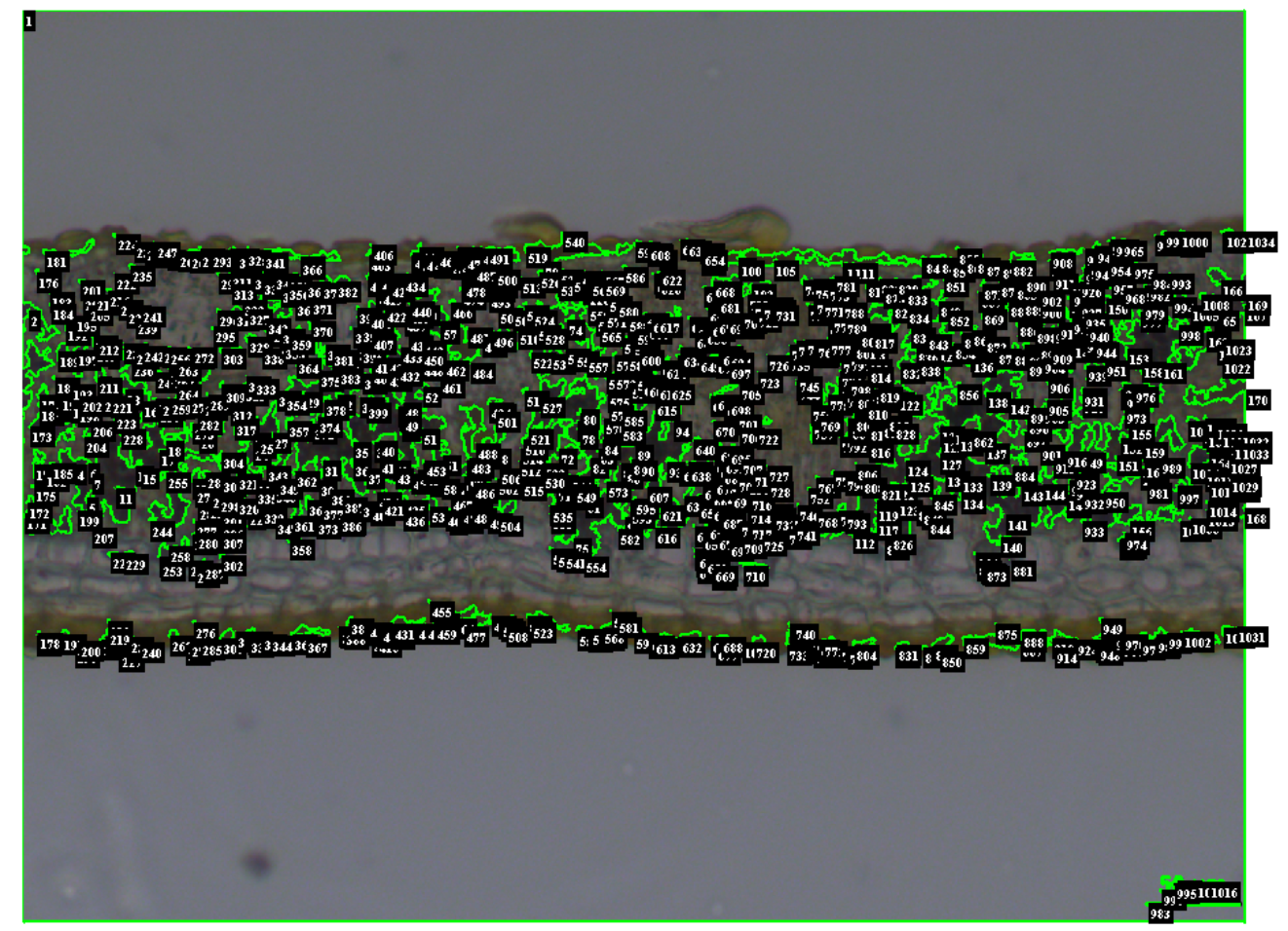

Figura 49 - E4 - Imagem com objetos de interesse destacados e etiquetados na imagem original. 


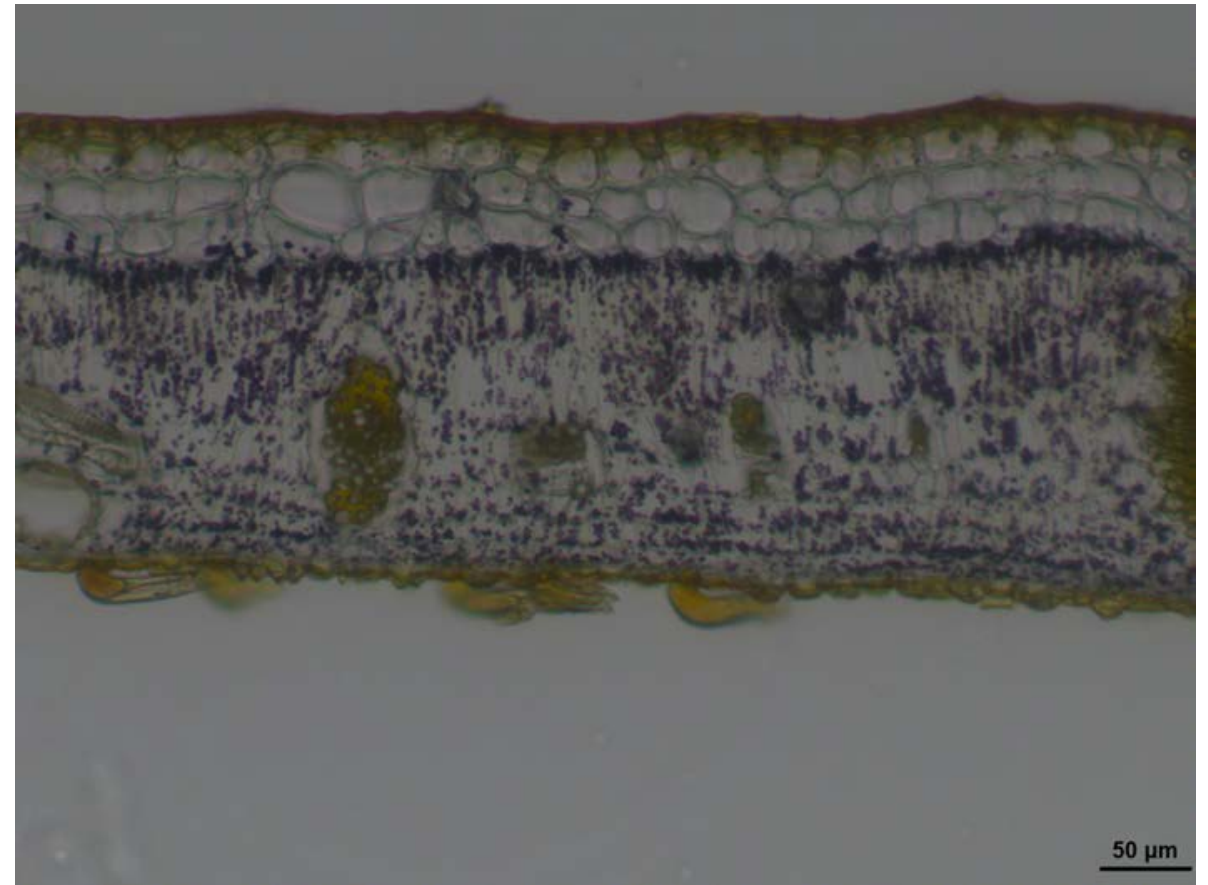

Figura 50 - E5 - imagem original - 18h.

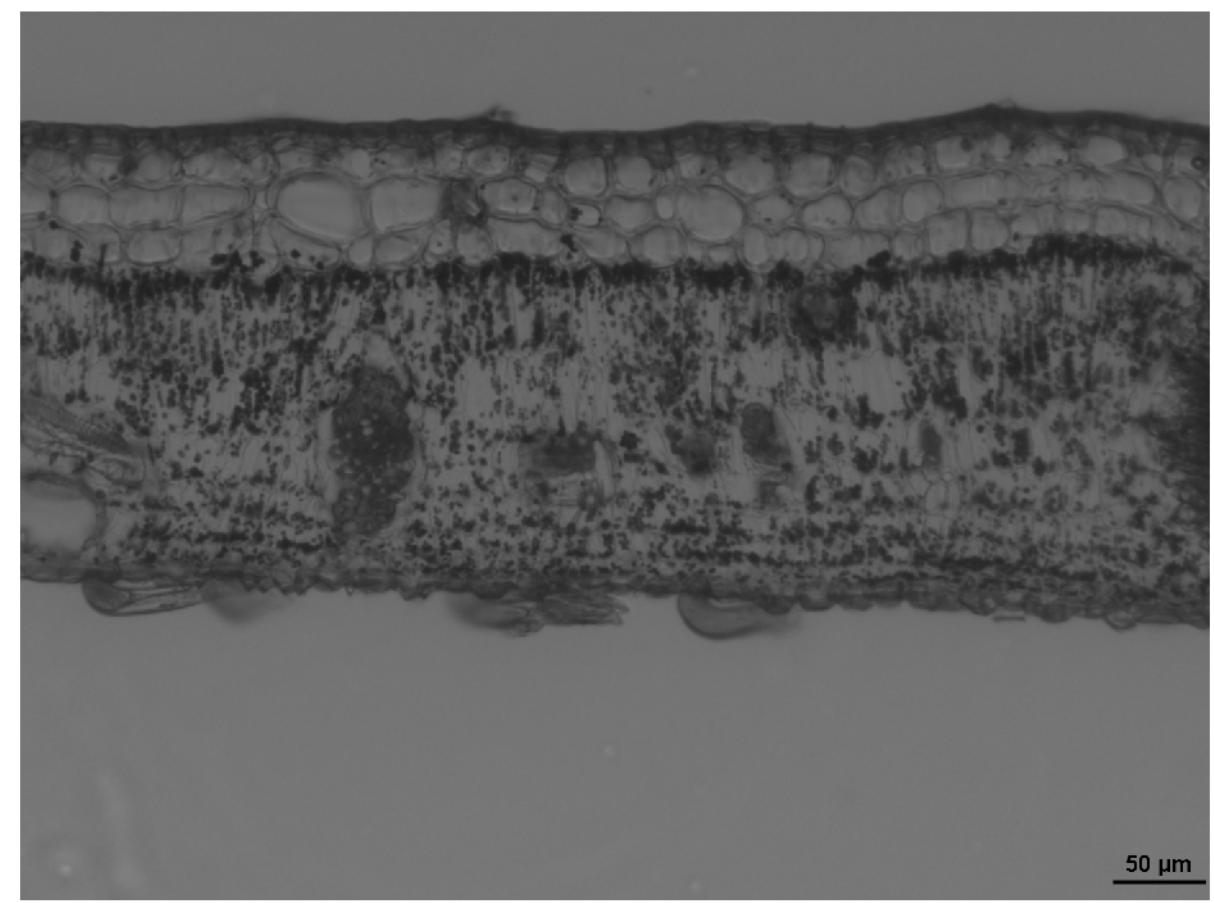

Figura 51 - E5 - Imagem em escala de cinza destacada do canal verde (G). 

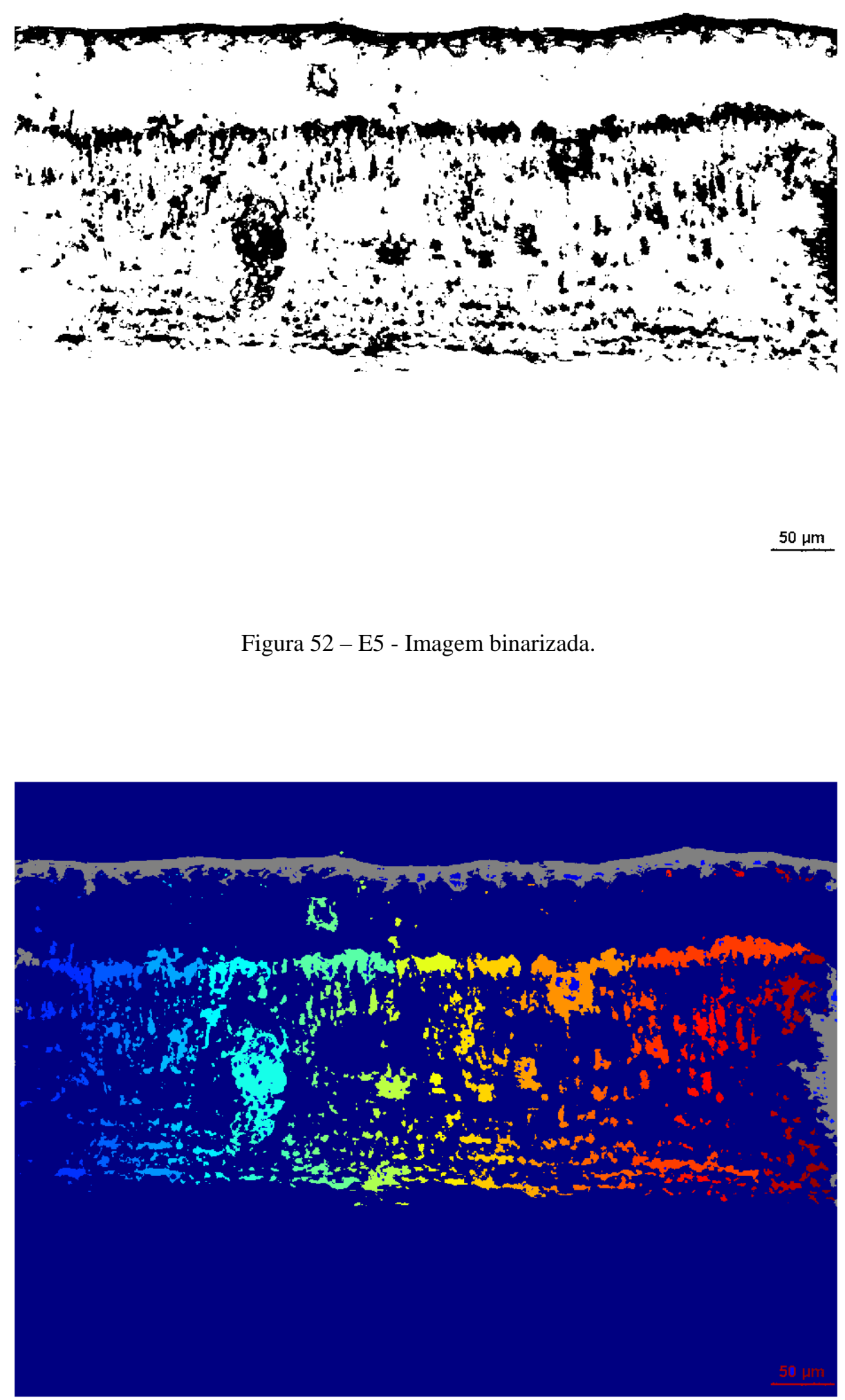

Figura 53 - E5 - Imagem com regiões destacadas por espalhamento de cor para facilitar interpretação de regiões de interesse. 


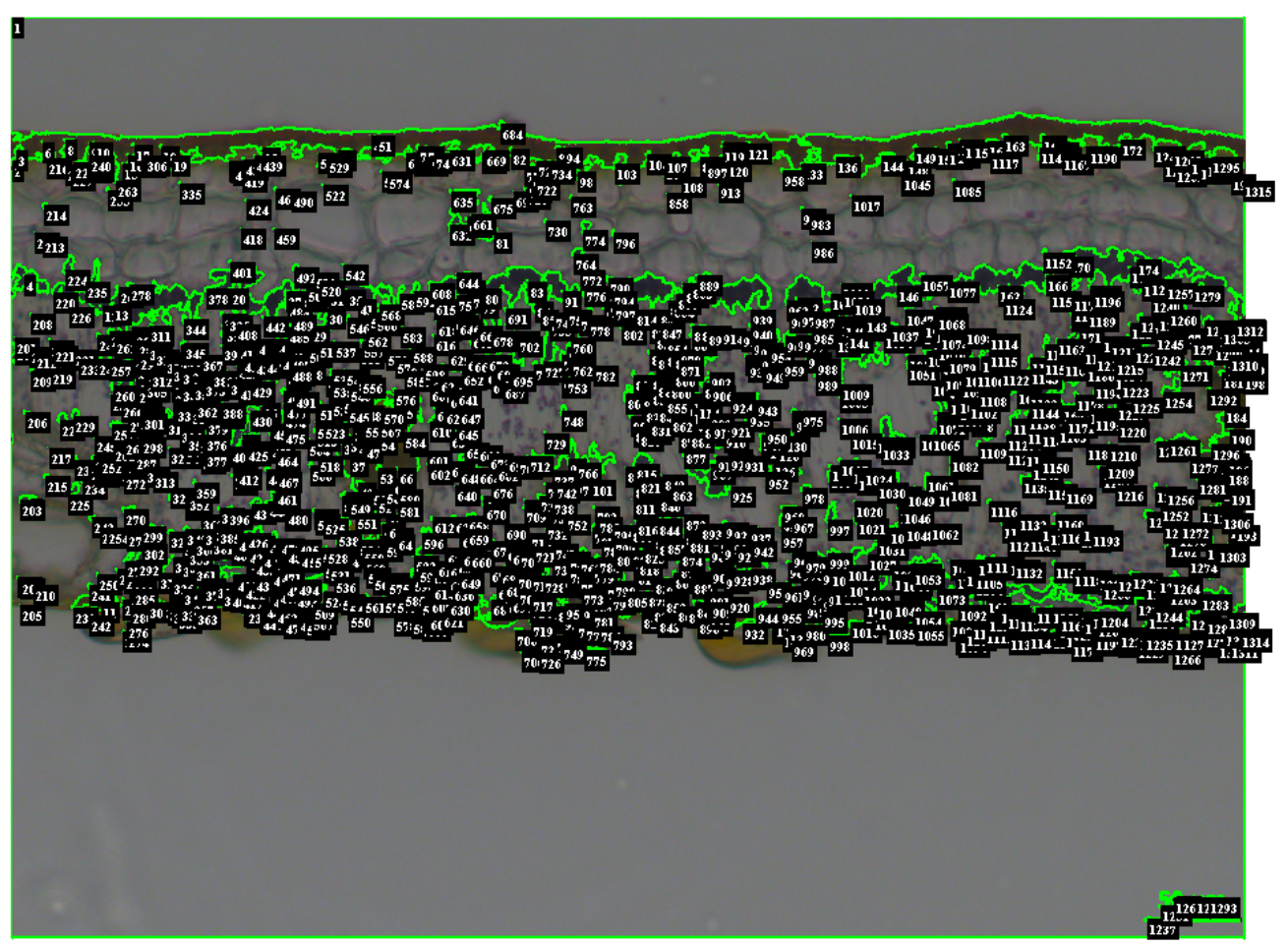

Figura 54 - E5 - Imagem com objetos de interesse destacados e etiquetados na imagem original. 


\subsection{Resultados e Discussões}

Da matriz AA extraída de cada imagem processada, compilamos a tabela com valores de área de pixels de interesse, mostrada na tabela 1 e exibidos na Figura 55.

Tabela 1 - Resultado com valores de área de pixels para as amostras de E1 à E5, amostras de 1 à 6 correspondentes à folha $\mathrm{A}$, de 7 à 12 correspondentes a folha $\mathrm{B}$ e amostras de 13 à 18 correspondentes à folha C.

\begin{tabular}{|c|c|c|c|c|c|}
\hline $\mathbf{N}$ & $\mathbf{O 1}$ & $\mathbf{O 2}$ & $\mathbf{0 3}$ & $\mathbf{0 4}$ & $\mathbf{0 5}$ \\
\hline $\mathbf{1}$ & $39.870,00$ & $10.186,00$ & $38.429,00$ & $75.916,00$ & $49.810,00$ \\
\hline $\mathbf{2}$ & $22.285,00$ & $11.308,00$ & $39.974,00$ & $79.757,00$ & $47.713,00$ \\
\hline $\mathbf{3}$ & $24.490,00$ & $9.251,00$ & $37.134,00$ & $79.432,00$ & $53.950,00$ \\
\hline $\mathbf{4}$ & $20.895,00$ & $10.629,00$ & $34.399,00$ & $63.138,00$ & $52.687,00$ \\
\hline $\mathbf{5}$ & $24.306,00$ & $11.003,00$ & $36.349,00$ & $90.578,00$ & $61.536,00$ \\
\hline $\mathbf{6}$ & $28.140,00$ & $11.094,00$ & $41.278,00$ & $78.512,00$ & $49.673,00$ \\
\hline $\mathbf{7}$ & $23.716,00$ & $12.295,00$ & $33.926,00$ & $66.621,00$ & $54.906,00$ \\
\hline $\mathbf{8}$ & $30.127,00$ & $14.277,00$ & $45.281,00$ & $77.275,00$ & $62.041,00$ \\
\hline $\mathbf{9}$ & $42.712,00$ & $12.112,00$ & $34.304,00$ & $62.913,00$ & $49.535,00$ \\
\hline $\mathbf{1 0}$ & $41.323,00$ & $13.147,00$ & $32.687,00$ & $73.136,00$ & $46.295,00$ \\
\hline $\mathbf{1 1}$ & $35.323,00$ & $9.694,00$ & $42.712,00$ & $71.580,00$ & $44.845,00$ \\
\hline $\mathbf{1 2}$ & $31.804,00$ & $10.051,00$ & $37.861,00$ & $73.489,00$ & $50.967,00$ \\
\hline $\mathbf{1 3}$ & $33.919,00$ & $10.484,00$ & $51.417,00$ & $71.560,00$ & $57.820,00$ \\
\hline $\mathbf{1 5}$ & $32.760,00$ & $11.246,00$ & $39.496,00$ & $79.467,00$ & $44.673,00$ \\
\hline $\mathbf{1 6}$ & $37.133,00$ & $11.647,00$ & $49.926,00$ & $89.288,00$ & $50.506,00$ \\
\hline $\mathbf{1 7}$ & $35.861,00$ & $13.241,00$ & $46.720,00$ & $92.181,00$ & $53.724,00$ \\
\hline $\mathbf{1 8}$ & $30.194,00$ & $14.762,00$ & $40.397,00$ & $86.460,00$ & $47.588,00$ \\
\hline
\end{tabular}

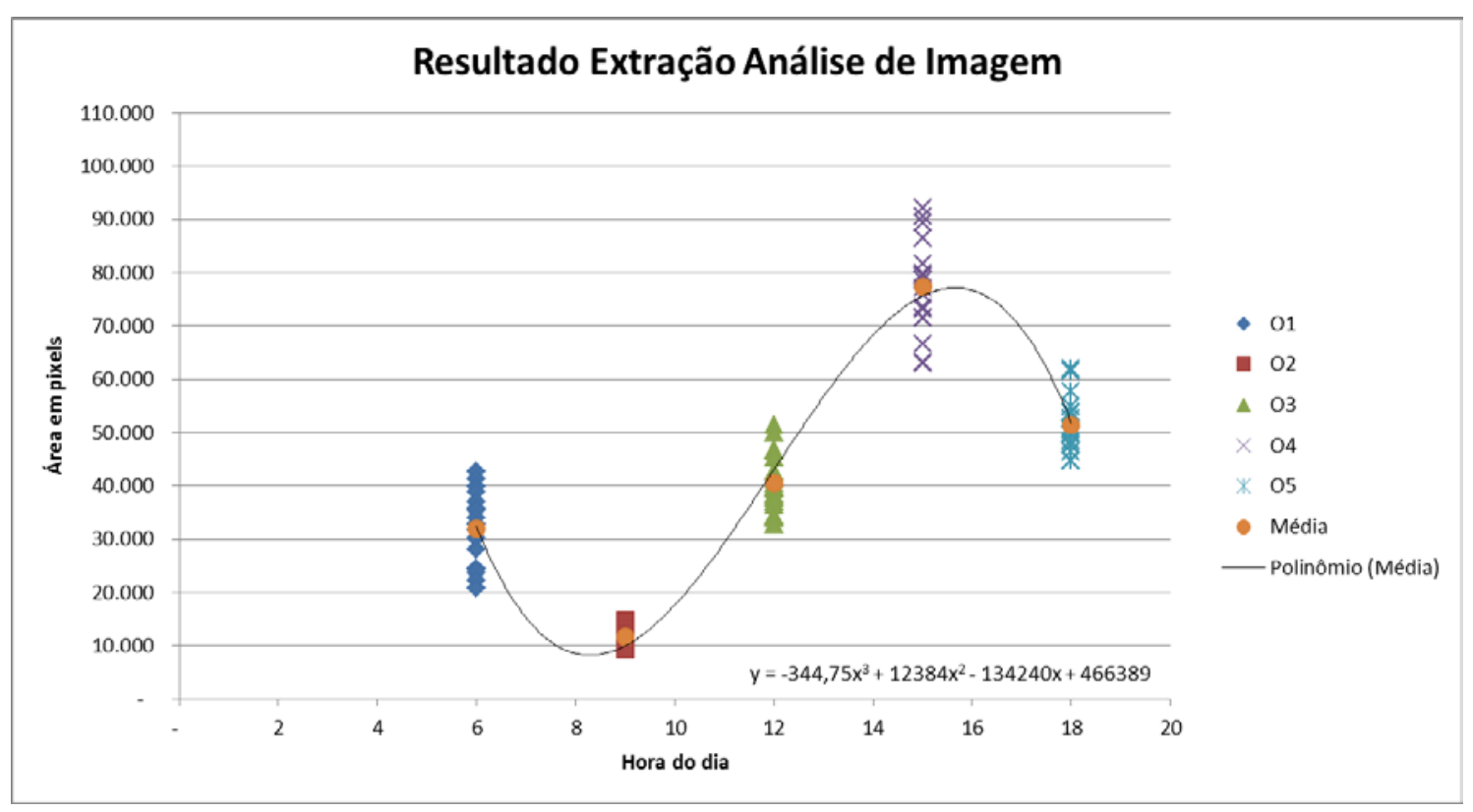

Figura 55 - Resultado da extração Análise de Imagem. 
Dos dados observados na extração e quantificação descrito em (Amaral, et al. 2007), em cinco horários distintos, considerados na fase 1 do procedimento, cujos resultados podem ser observados na figura 28, extraímos a tabela 2 e exibidos na Figura 56.

Tabela 2 - Resultado com valores de ug AMIDO /mg Massa Seca de amostras de E1 à E5, amostras de 1 e 2 correspondentes à folha $\mathrm{A}$, de 3 e 4 correspondentes Á folha $\mathrm{B}$ e amostras de 5 e 6 correspondentes à folha $\mathrm{C}$, renomeadas para amostras reais observadas de $\mathrm{O} 1$ à $\mathrm{O} 5$.

\begin{tabular}{|c|r|r|r|r|l|}
\hline $\mathbf{N}$ & \multicolumn{1}{|c|}{ E1 } & E2 & E3 & E4 & \multicolumn{1}{c|}{ E5 } \\
\hline $\mathbf{1}$ & 9,407 & 6,169 & 12,828 & 18,652 & 11,949 \\
\hline $\mathbf{2}$ & 9,557 & 6,861 & 9,922 & 21,032 & 12,819 \\
\hline $\mathbf{3}$ & 8,235 & 4,561 & 7,554 & 21,133 & 11,118 \\
\hline $\mathbf{4}$ & 10,208 & 3,563 & 9,844 & 23,566 & 14,095 \\
\hline $\mathbf{5}$ & 10,294 & 5,309 & 10,389 & 21,772 & 15,790 \\
\hline $\mathbf{6}$ & 11,664 & 5,815 & 11,895 & 22,338 & 14,036 \\
\hline
\end{tabular}

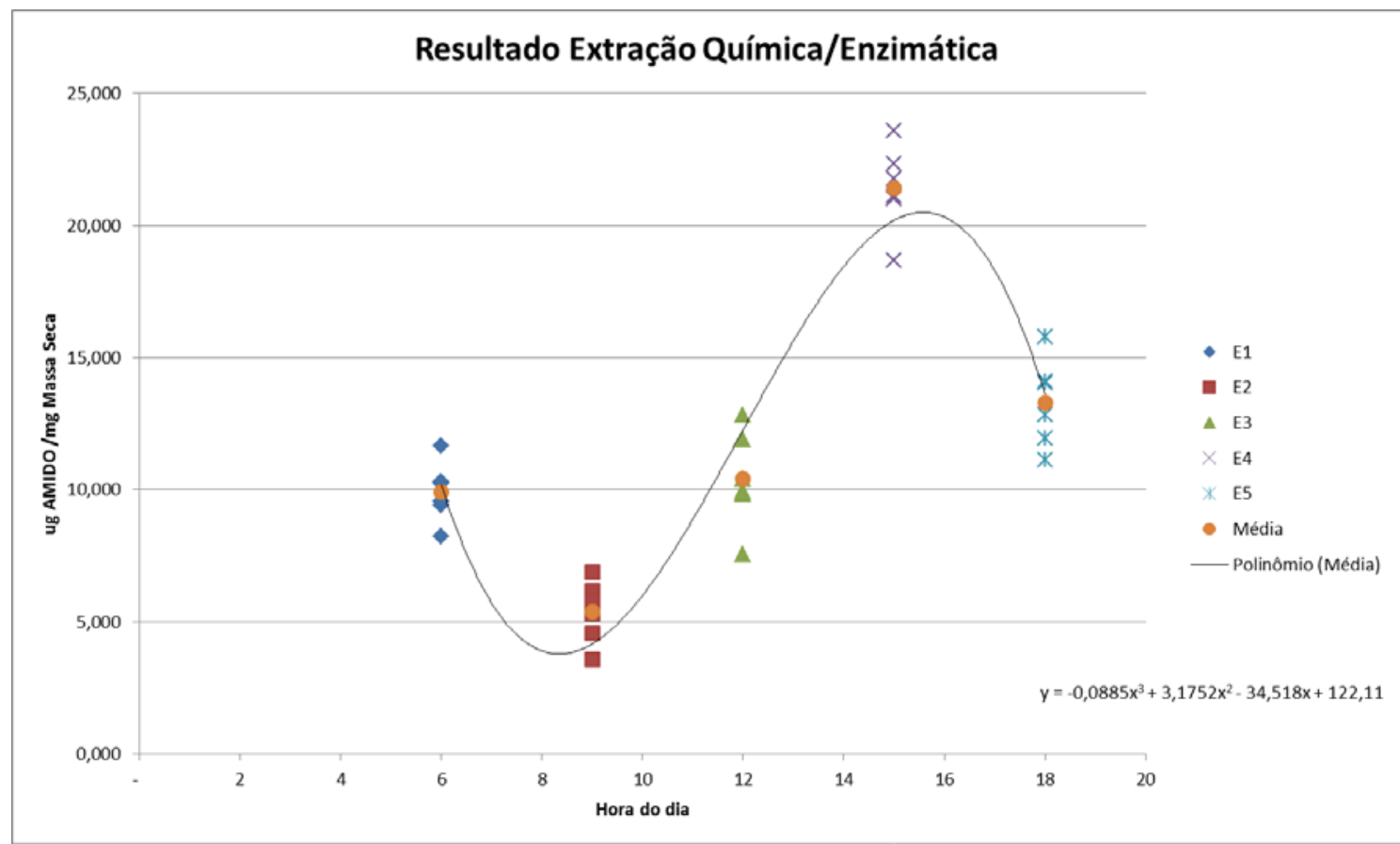

Figura 56 - Resultado da extração Química / Enzimática descrita em (Amaral, et al. 2007).

Para nossa proposta de sensoriamento, o modelo extraído das imagens processadas deve guardar interdependência com o modelo extraído através da técnica descrita em (Amaral, et al. 2007), sendo esse considerado o resultado real observado.

Definimos o conjunto de pontos Observados, para cada horário de amostragem definido de um dia de 24h de duração, como na equação (3). 


$$
O_{n}=\left\{q_{1}, q_{2}, \ldots, q_{m}\right\}
$$

Definimos o conjunto de pontos Esperados, para cada horário de amostragem definido de um dia de 24h de duração, como na equação (4).

$$
E_{n}=\left\{p_{1}, p_{2}, \ldots, p_{m}\right\}
$$

Definimos a hipótese de interdependência em que há relação tal que, dado um ganho k, conhecida e mantida a ordem do polinômio característico da curva elaborada com a média dos $m$ pontos $p$ de cada $n$ ponto $E$ do conjunto definido na equação (4) representado na equação (5), guarda relação com a curva elaborada com a média dos $m$ pontos $q$ de cada $n$ ponto $\mathrm{O}$ do conjunto definido na equação (3), representado na equação (6), chegando na equação do ganho (7).

$$
\begin{gathered}
E_{n}=\frac{1}{m}\left(\sum_{j=1}^{m}\left\{p_{j}\right\}\right) \\
O_{n}=\frac{1}{m}\left(\sum_{j=1}^{m}\left\{q_{j}\right\}\right) \\
O_{n} * k_{n}=E_{n}
\end{gathered}
$$

Para realizar um teste de independência ou homogeneidade, a probabilidade quiquadrada menor ou igual à 0,05 indica a interpretação de rejeição da hipótese nula de independência entre os conjuntos esperados e observados, correspondendo então a hipótese alternativa de associação ou relação em que há correlação e interdependência entre os conjuntos, sendo assim possível a utilização de um para inferir sobre quantificação do outro, sendo afinal possível medir de forma indireta a grandeza esperada através de dados observados.

Foram realizados testes de independência para os conjuntos de pontos Observados $O_{n}$ com ganho k, como visto na tabela (3), e Esperados $E_{n}$, como visto na tabela (2), para cada $n$, de $n=1 a n=5$. A relação entre as populações observadas e esperadas é de 3:1, então foi realizada equalização de população para tornar possível o teste de independência. A equalização foi realizada selecionando-se ao acaso um subconjunto de pontos Observados de mesmo tamanho do conjunto de pontos Esperados, cada subconjunto com ordenação aleatória. 
Tabela 3 - Conjunto de pontos observados com ganho k.

\begin{tabular}{|c|c|c|c|c|c|}
\hline $\mathbf{N}$ & $01 * \mathrm{k}=\mathrm{E} 1$ & $02 * k=E 2$ & O3* $\mathrm{k}=\mathrm{E} 3$ & $04 * k=E 4$ & $05 * \mathrm{k}=\mathrm{E} 5$ \\
\hline 1 & 12,375 & 4,669 & 9,876 & 21,009 & 12,871 \\
\hline 2 & 6,917 & 5,183 & 10,273 & 22,072 & 12,329 \\
\hline 3 & 7,601 & 4,240 & 9,543 & 21,982 & 13,940 \\
\hline 4 & 6,486 & 4,872 & 8,840 & 17,472 & 13,614 \\
\hline 5 & 7,544 & 5,043 & 9,341 & 25,066 & 15,901 \\
\hline 6 & 8,734 & 5,085 & 10,608 & 21,727 & 12,835 \\
\hline 7 & 7,361 & 5,636 & 8,718 & 18,436 & 14,187 \\
\hline 8 & 9,351 & 6,544 & 11,636 & 21,385 & 16,031 \\
\hline 9 & 13,257 & 5,552 & 8,815 & 17,410 & 12,800 \\
\hline 10 & 12,826 & 6,026 & 8,400 & 20,239 & 11,962 \\
\hline 11 & 10,964 & 4,443 & 10,976 & 19,809 & 11,588 \\
\hline 12 & 9,872 & 4,607 & 9,730 & 20,337 & 13,170 \\
\hline 13 & 10,528 & 4,806 & 13,213 & 19,803 & 14,940 \\
\hline 14 & 10,168 & 5,155 & 10,150 & 21,991 & 11,543 \\
\hline 15 & 11,526 & 5,339 & 12,830 & 24,709 & 13,051 \\
\hline 16 & 11,131 & 6,069 & 12,006 & 25,510 & 13,882 \\
\hline 17 & 9,372 & 6,766 & 10,381 & 23,927 & 12,297 \\
\hline 18 & 12,083 & 6,802 & 11,963 & 22,593 & 12,480 \\
\hline
\end{tabular}

Para cada $n$, foram realizados 50 testes de independência para 50 subconjuntos distintos dos valores do conjunto Observado, e da combinação do conjunto dos subconjuntos de cada $n$ com o conjunto dos conjuntos de valores Esperados, com resultados mostrados na tabela 4. 
Tabela 4 - Resultado dos testes de independência.

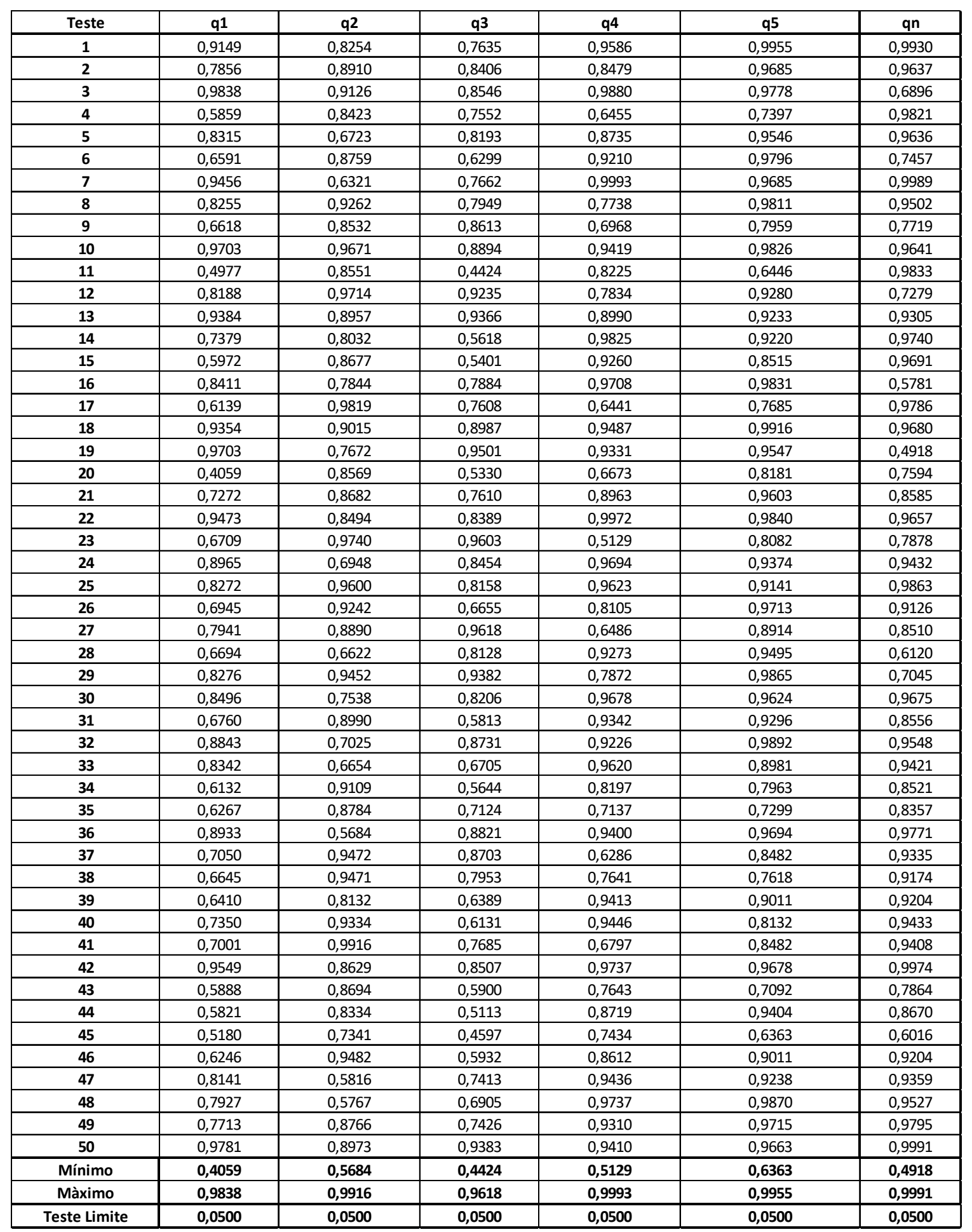

Para todos os testes realizados, a hipótese nula não foi rejeitada, assim não existindo diferença entre os valores Observados e Esperados.

A figura 57 exibe o resultado da reconstrução da curva de amido pelos pontos observados aplicado ganho $\mathrm{k}$. 


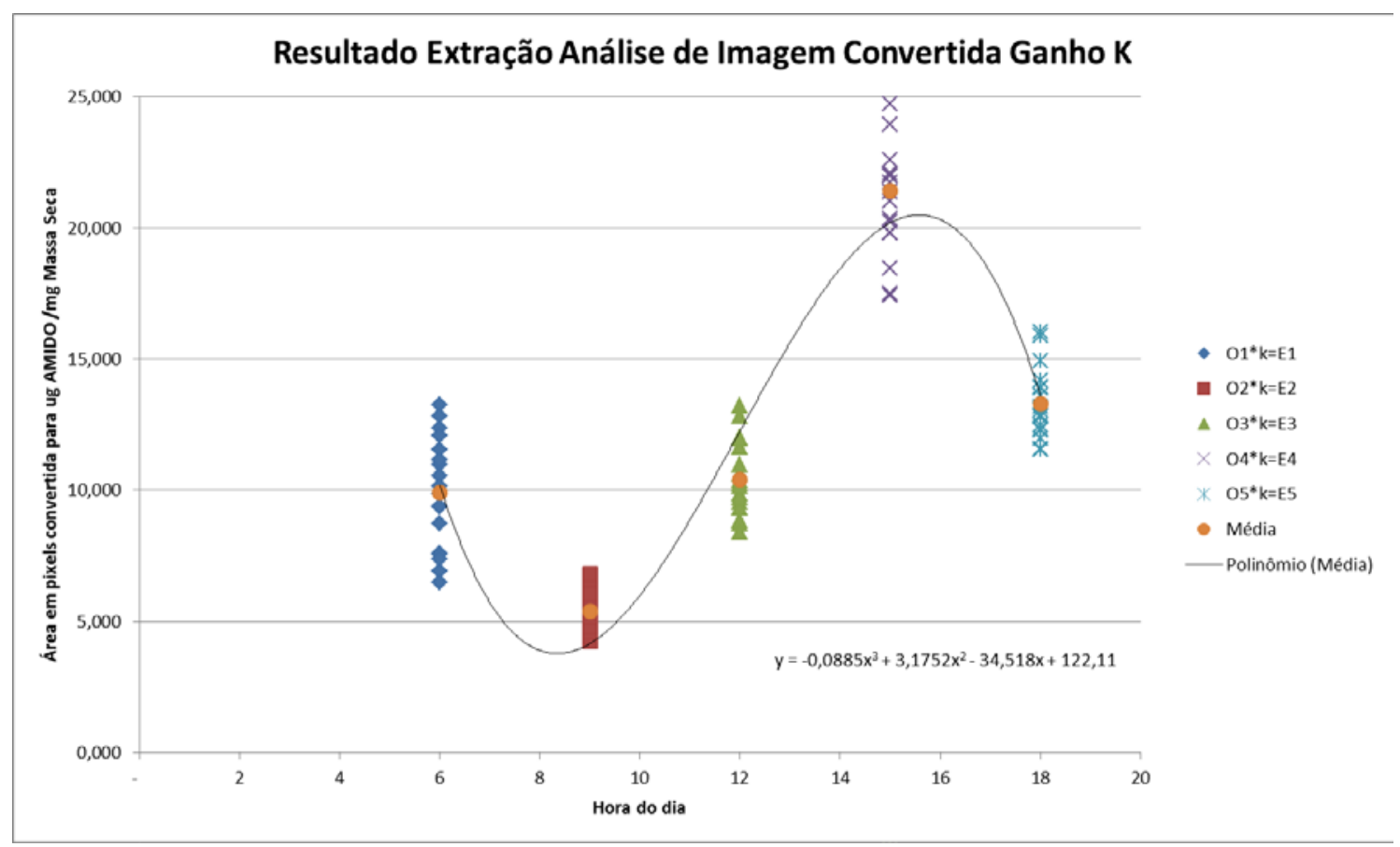

Figura 57 - Resultado da extração Análise de Imagem aplicado ganho k.

\section{Conclusões}

Do resultado obtido da comparação entre modelo atual e um modelo de método de sensoriamento de amido em folhas de plantas proposto, depois de verificado e validado, é possível afirmar que baseado na observação e tratamento de imagens de cortes padronizados de secção transversal de folhas, com posterior processamento de imagem e verificação por ganho k e curva de calibração, é possível medir de forma indireta amido em folhas de plantas utilizando o método proposto.

Os tempos entre amostragem de folha, montagem de lâminas, observação em microscopia de luz, obtenção de imagem para cada corte e posterior processamento de imagem, cerca de 40 minutos de processo completo, são muito inferiores aos necessários para obtenção dos valores de amido da extração Química / Enzimática descrita em (Amaral, et al. 2007), que levam cerca de $48 \mathrm{~h}$ a 72h para obtenção do resultado de cada amostra.

Com a redução de tempo para cerca de 40 minutos, por conjunto amostrado e observado, o resultado obtido pode ser inserido em um sistema de controle de malhar fechada, realimentando a informação de estoque transitório de energia da planta através do amido nas folhas, com possibilidades de utilização dessa informação dentro de um ciclo de 24h, para 
ações de controle que visem otimizar o crescimento das plantas, acelerar seu crescimento ou retardar seu crescimento. É possível expandir as medições de forma escalável, paralelizando o conjunto de amostragem aumentando o conjunto amostrado, uma vez que o tempo de processamento das imagens é bem inferior ao tempo de coleta de amostras.

A utilização de iluminação artificial para o crescimento de plantas, seja como fonte suplementar de luz ou como fonte primária, necessita da informação de estoque transitório de energia, como um dentre outros fatores que atuam no sistema de previsão de fotoinibição.

Essa proposta de sensor, e sua informação associada, abre espaço para novas discussões a respeito do crescimento de plantas em ambiente controlado com sistemas de controle em malha fechada, proporcionando uma gama de novas possibilidades de pesquisa e desenvolvimento.

Para melhor entendimento da técnica proposta e sua aplicabilidade, novos trabalhos devem ser desenvolvidos testando diferentes cultivares, além de através da base apresentada nesse trabalho, avançar em formas de medição com ensaios não destrutivos.

Outras aplicações como a de uso médico para pacientes com diabetes que necessitam verificação constante de contagem de carboidratos em alimentos, um mercado de grande aplicação. 


\section{Referências}

Altunbasak, Yucel, Erhan Eren, e A. Murat Tekalp. "Region-Based Parametric Motion Segmentation Using Color Information.” GRAPHICAL MODELS AND IMAGE PROCESSING 60, n. № 1 (1998): 13-23.

Amaral, Lourdes Isabel Velho do, Mrília Gaspar, Paula Moreira Felix Costa, Marcos Pereira Marinho Aidar, e Marcos Silveira Buckeridge. "Novo método enzimático rápido e sensível de extração e dosagem de amido em materiais vegetais.” Hoehnea 34(4) (2007): p.425-431.

Barbedo, Jayme Garcia Arnal. "Using digital image processing for counting whiteflies on soybean leaves.” Journal od Asia-Pacific Entomology 17 (2014): p.658-694.

Beck, Charles B. An introduction to plant structure and development: plant anatomy for the twenty-first century. Cambridge: UK Cambridge University, 2005.

Bell, Adrian D. Plant Form An illustrated guide to flowering plant morphology. Portland : Timber Press, 2008.

Bold, H. C. Morphology of Plants, Second Edition. New York Harper \& Row, 1967.

Brown, Horace T., e G. Harris Morris. "A contribution to the chemistry and physiology of foliage leaves.” 63 (1893): 604-677.

Buvat, Roger. ontogeny, cell differenciation, and structure of vascular plants. Berlin, New York: Springer-Verlag, 1989.

Campbell, Neil A., Jane B. Reece, e Lawrence G. Mitchell. Biology. Menlo Park,: Calif. Benjamin Cummings, 1999.

Chatterton, N. Jerry, e John E. Silvius. "Photosynthate Partitioning into Starch in Soybean Leaves.” Plant Physion Vol.64 (1979): p.749-753.

Chung, C. A. "SIMULATION MODELING HANDBOOK A Practical Approach." CRC Press Taylor and Francis Group., 2004.

Crumpton-Taylor, $\mathrm{M}$, et al. "Starch synthase 4 is essential for coordination of starch granule formation with cloroplast division during Arabidopsis leaf expansion.” New Phytol 200 (2013): 1064-1075.

Edwards, Diane, Peter Jolliffe, e David Ehret. "canopy profiles of starch and leaf mass per area in greenhouse tomato and the relationship with leaf area and fruit growth." Scientia Horticulturae 125 (2010): p.637-647.

Etyngier, Patrick, Florent Segonne, e Renaud Keriven. "Active-Contour-Based Image Segmentation using Machine Learning Techniques.” 10th International Conference, Brisbane, Australia, October 29 - November 2. Brisbane: Springer Berlin Heidelberg, 2007. 891-899.

—. "Shape Priors using Manifold Learning Techniques.” Computer Vision, 2007. ICCV 2007. IEEE 11th International Conference on 14-21 Oct. . Rio de Janeiro: IEEE, 2007. 1-8.

Evert, Ray F., e Susan E. Eichhorn. Raven: Biologia Vegetal . $8^{\text {a }}$ Edição. Rio de Janeiro: Guanabara Koogan, 2014.

Factor, T. L., J. A. C. Araujo, F.P.C KAWAKAMI, e V. IUNCK. "Produção de minitubérculos básicos de batata em três sistemas hidropônicos.” Hortic. Bras., janmar de 2007.

Felzenszwalb, Pedro F., e Daniel P. Huttenlocher. "Efficient Graph-Based Image Segmentation.” International Journal of Computer Vision 59 (2004): 167-181.

Feugier, François G., e Akiko Satake. "Hyperbolic features of the circadian clock oscillations can explainlinearity in leaf starch dynamics and adaptation of plants to diverselight and dark cycles.” Ecological Modelling 290 (2014): 110-120. 
Geigenberger, Peter. "Regulation of Starch Biosynthesis in Response to a Fluctating Environment.” Plant Physiology vol. 155 (April 2011): pp. 1566-1577.

Gibson, Kelly, et al. "Exploiting leaf starch syntesis as a transient sink to elevate photosyntesis, plant productivity and yields.” Plant Science 181 (2011): p.275-281.

Gonzalez, R. C., Woods, R. E., Eddins, S. L. Digital Image Processing Using MATLAB. New Jersey: Pearson Prentice Hall, 2004.

Gonzalez, Rafael C., e Richard E. Woods. Processamento de imagens digitais. São Paulo: Edgard Blucher Ltda., 1992.

Graf, A, A Schlereth, M Stitt, e A.M. Smith. "Circadian control of carbohydrate avaliability for growth in Arabidopsis plants at night.” PNAS 107, n. 20 (may 2010): p.9458-9463.

Graf, Alexander, e M. Alison Smith. "Starch and the clock: the dark side of plant productivity.” Trends in Plant Science Vol. 16, n. No. 3 (March 2011): p169-175.

Gunning, Brian E. S., e Martin W. Steer. Plant Cell Biology an ultrastructural approach. London: Edward Arnold (Publishers) Ltd., 1975.

Haissig, B.E, e R.E. Dickson. "Starch measurement in plant tissue using enzymatic hydrolisis.” Physiologia Plantarum 47 (1979): p.151-157.

Khan, Ahmad, e Muhammad Arfan Jaffar. "Genetic algorithm and self oganizing map based fuzzy hybrid intelligent method for color image segmentation.” Applied Soft Computing 32 (2015): 300-310.

LEHNINGER, A.L., D.L. NELSON, e M.M. COX. Princípios de bioquímica. São Paulo: Sarvier, 1995.

Lloyd, James Richard, e Jens Kossmann. "Transitory and storage starch metabolism: two sides od the same coin?” Current Opinion in Biotechnology 32 (2015): 143-148.

Mahmood, Nasrul Humaimi, e Muhammad Asraf Mansor. "Red blood cells estimation using hough transform technique." Signal \& Image Processing: An International Journal (SIPIJ) Vol.3, n. ed. 2 (april 2012): 53-64.

McCready, R.M., J. Guggolz, V. Silviera, e H.S. Owens. "Determination of starch and amylose in vegetables.Application to peas." Analytical Chemistry 22 (1950): p.11561158.

McRae, J.C. “Quantitative measurement of starch in very small mounts of leaf tissue.” Planta 96 (1971): p.101-108.

Mello, S. da C. "Suplementação luminosa.” Revista pesquisa fapesp, n. edição 225 (2014): pg. 16.

Mueller, Marina, Karl Segl, e Hermann Kaufmann. "Edge- and region-based segmentation technique for the extraction of large, man-made objects in high-resolution satellite imagery." Pattern Recognition - The Journal of Pattern Recognition Society 37 (2004): 1619-1628.

Otsu, N. "A threshold selection method from gray level histograms.” IEEE Trans. Syst. Man Cybern SMC-9 (1979): 62-66.

Pan, Jie, Yan Zhu, e Weixing Cao. "Modeling plant carbon flow and grain starch accumulation in wheat.” Field Crops Research 101 (2007): p.276-284.

Pantin, F, T Simonneau, G Rolland, M Dauzat, e B Muller. "Control od leaf expansions: a developmental switch from metabolics to hydraulics.” Plant Physiol 156 (2011): p. 803-815.

Pieczynski, Wokciech. “Statistical Image Segmentation.” Proceedings of 2nd International Conference on Computer Graphics and Image Processing (GKPO'92), May 18-23. Nalçczów, Poland, 1992. 261-268.

Reffye, P. De., e B. G. Hu. "Relevant Qualitative and Quantitative choices for building an efficient dynamic plant growth model : Greenlab Case.” International Symposium on 
Plant Growth Modeling, Simulation, Visualization and their Applications, 2003, PMA'03 ed.: pp.87-107.

Santacruz, S., R. Andersson, e P. Aman. "Characterisation of potato leaf starch with iodinestaining.” Carbohydrate Polymers 59 (2005): p.397-400.

SEELING, H.D, R.J. STONER, e J.C. LINDEN. "Irrigation control of cowpea plants using the measurement of leaf thickness under greenhouse conditions." Irri. Sci. DOI 10.007/s00271-011-0268-2, 2011.

Sezgin, Mehmet, e Bülent Sankur. "Survey over image thresholding techniques and quantitative performance evaluation.” Journal of Electronic Imaging 13(1) (2004): 146-165.

Smith, Alison M. "Starch in the Arabidopsis plant.” Starch 64 (2012): p.421-434 .

Stitt, Mark, e Samuel C. Zeeman. "Starch turnover: pathways, regulation and role in growth." Current Opinion in Plant Biology 15 (2012): p.282-292.

TAIZ, L., e E. ZEIGER. Fisiologia Vegetal $3^{a}$ Ed. Porto Alegre: Artmed, 2002.

The Arabidopsis Genome Initiative*. "Analysis of the genome sequence of the flowering plant Arabbidopsis thaliana.” NATURE, DECEMBER 2000: p.796-815.

The Pennsylvania State University. “Copyright (C) 2015.” s.d. https://online.science.psu.edu/sites/default/files/chem005/Chem-005-F07-1-1-1.jpg (acesso em 01 de Agosto de 2015).

Wang, Hongzhi, e John Oliensis. "Generalizing Edge Detection to Contour Detection for Image Segmentation.” Computer Vision and Image Understanding 114(7) (2010): 731-744.

Weier, Thomas Elliot. Botany: an introduction to plant biology. New York: John Wiley, 1982.

Xiang-yang, Wang, Sun Wei-wei, Wu Zhi-fang, Yang Hong-ying, e Wang Qin-yan. "Color image segmentation using PDTDFB domain hidden Markov tree model." Applied Soft Computing 29 (2015): 138-152.

Zhu, Fan, Eric Bertoft, You Wang, Michael Emes, Ian Tetlow, e Koushik Seetharaman. "Structure of Arabidopsis leaf starch is markedly altered following nocturnal degradation.” Carbohydrate Polymers, 2015: p.1002-1013. 